\title{
Monitoring Recharge in Areas of Seasonally Frozen Ground in the Columbia Plateau and Snake River Plain, Idaho, Oregon, and Washington
}

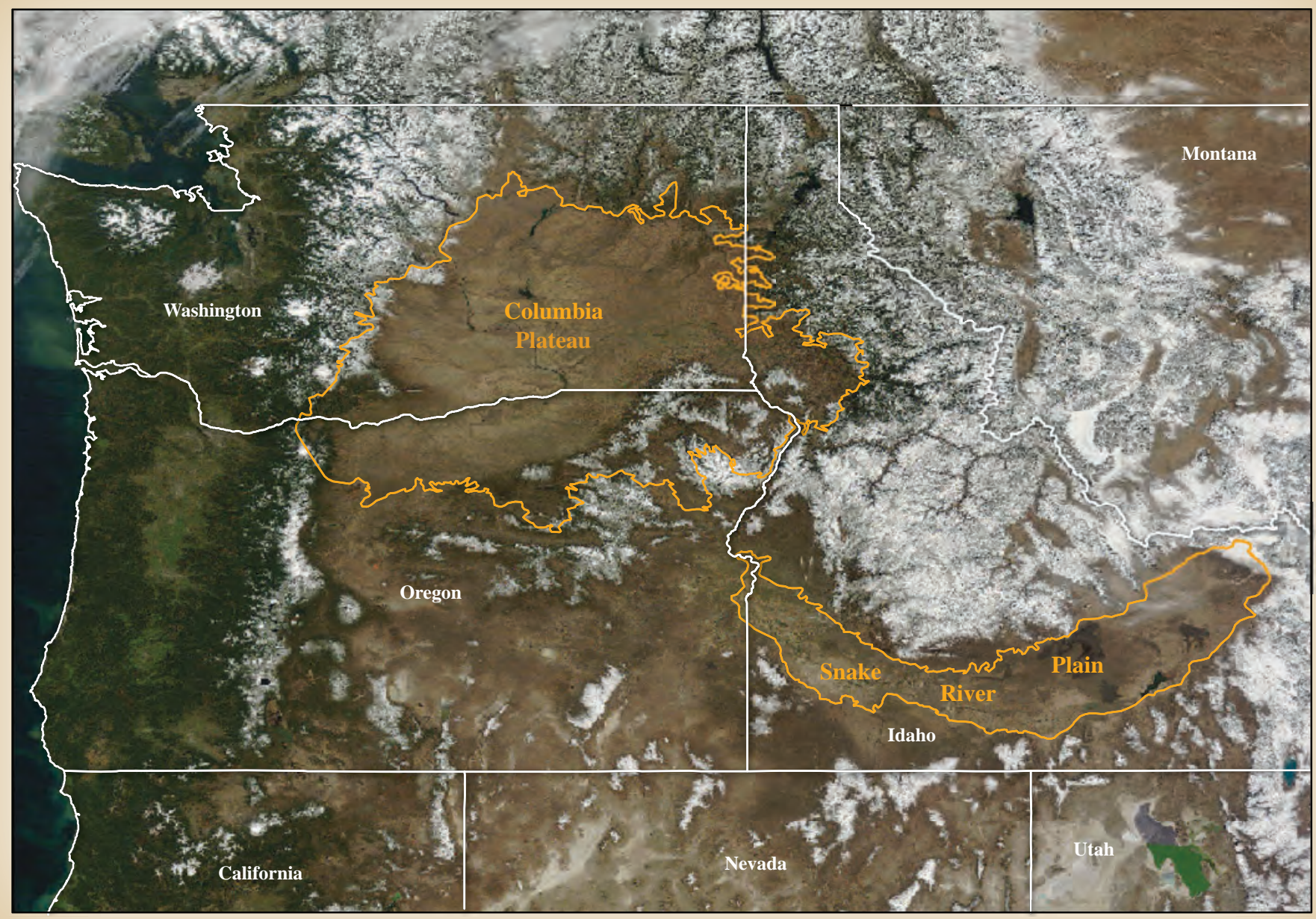

Scientific Investigations Report 2014-5083 
Cover: Satellite image of the Pacific Northwest acquired March 12, 2014 by the

Moderate Resolution Spectroradiometer (MODIS) on National Aeronautics and Space Administration's (NASA's) Terra satellite NASA. The image is provided courtesy of Jeff Schmaltz, LANCE/EOSDIS MODIS Rapid Response Team at NASA Goddard Space Flight Center, accessed May 15, 2014 at http://earthobservatory.nasa.gov/IOTD/view. php?id+83435. 


\section{Monitoring Recharge in Areas of Seasonally Frozen Ground in the Columbia Plateau and Snake River Plain, Idaho, Oregon, and Washington}

By Mark Mastin and Edward Josberger

Groundwater Resources Program

Scientific Investigations Report 2014-5083 


\title{
U.S. Department of the Interior SALLY JEWELL, Secretary
}

\section{U.S. Geological Survey Suzette M. Kimball, Acting Director}

\author{
U.S. Geological Survey, Reston, Virginia: 2014
}

For more information on the USGS - the Federal source for science about the Earth, its natural and living resources, natural hazards, and the environment, visit http://www.usgs.gov or call 1-888-ASK-USGS.

For an overview of USGS information products, including maps, imagery, and publications, visit http://www.usgs.gov/pubprod

To order this and other USGS information products, visit http://store.usgs.gov

Any use of trade, firm, or product names is for descriptive purposes only and does not imply endorsement by the U.S. Government.

Although this information product, for the most part, is in the public domain, it also may contain copyrighted materials as noted in the text. Permission to reproduce copyrighted items must be secured from the copyright owner.

Suggested citation:

Mastin, Mark, and Josberger, Edward, 2014, Monitoring recharge in areas of seasonally frozen ground in the Columbia Plateau and Snake River Plain, Idaho, Oregon, and Washington: U.S. Geological Survey Scientific Investigations Report 2014-5083, 64 p., http://dx.doi.org/10.3133/sir20145083.

ISSN 2328-0328 (online) 


\section{Contents}

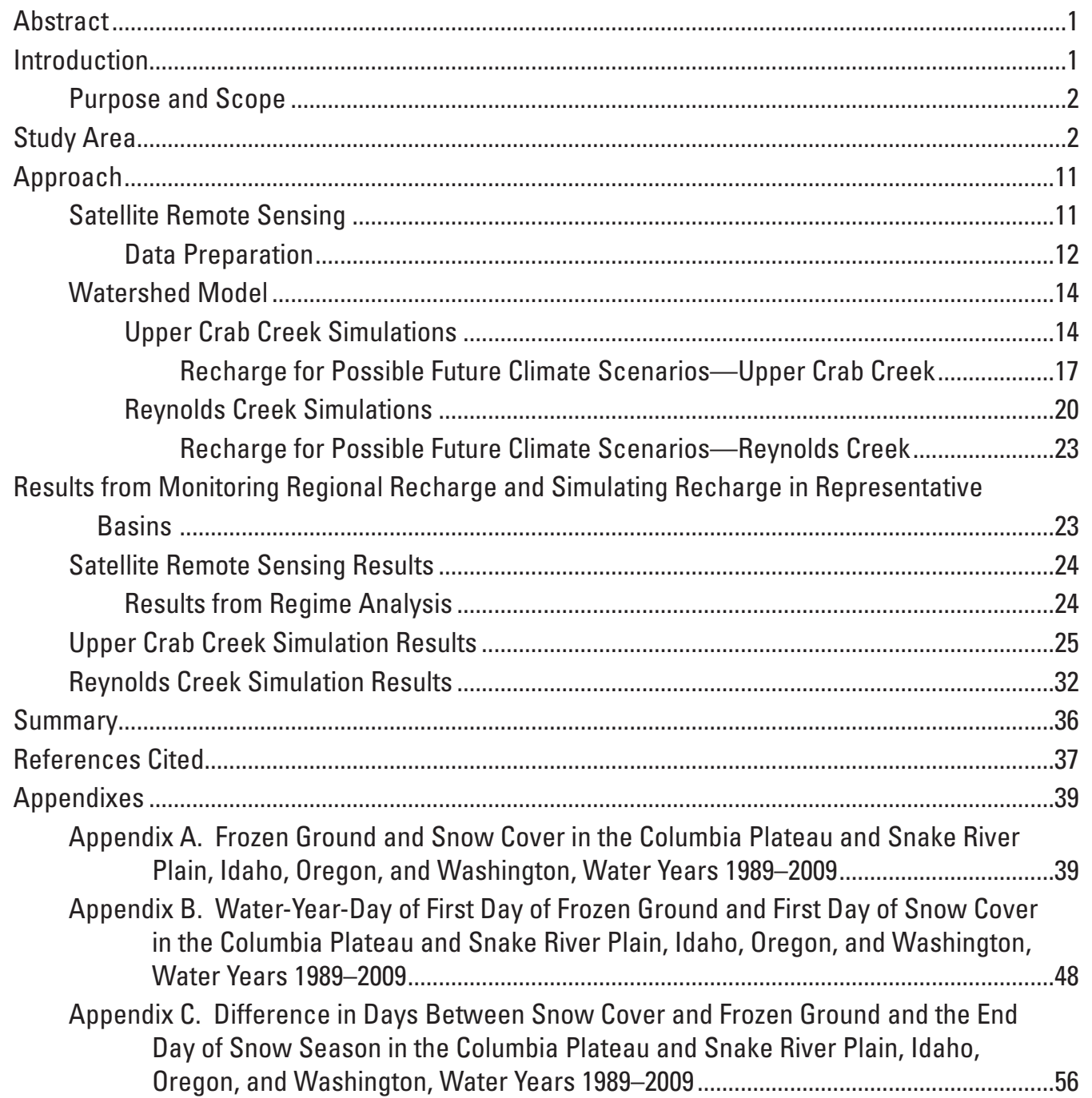




\section{Figures}

1. Map showing satellite remote-sensing and Columbia Plateau boundaries, Idaho, Oregon, and Washington.

2. Map showing satellite remote-sensing and Snake River Plain boundaries, Idaho and Oregon

3. Map showing mean annual precipitation in the Columbia Plateau and Snake River Plain study areas, Idaho, Oregon, and Washington, 1971-2000

4. Maps showing soil temperature from 4-inch-soil depth for average annual water-year day for the first freeze, percentage of years with temperatures less than freezing, and average annual days of frozen ground, Columbia Plateau and Snake River Plain study areas, Idaho, Oregon, and Washington, 1996-2010......

5. Graphs showing precipitation and daily discharge for U.S. Geological Survey streamflow-gaging station Crab Creek at Irby, Washington, January 1 to March 9, water years 1957 and 2004

6. Maps showing satellite remote sensing data for frozen ground and snow cover, Columbia Plateau and Snake River Plain study areas, Idaho, Oregon, and Washington, water year 2006 .

7. Graph showing soil temperature from direct measurements and satellite data for an AgriMet site at Picabo, Idaho, water year 1996.

8. Graph showing example time series of the progression from bare ground to frozen ground and then to snow-covered ground at an AgriMet site at Picabo, Idaho, water year 1991

9. Map showing existing watershed model boundaries for simulating inflows to Potholes Reservoir and the Upper Crab Creek Model used for this study,

Washington

10. Map showing watershed model boundaries and model sites in the Reynolds Creek Basin, Idaho

11. Graph showing number of days that simulated Continouous Frozen Ground Index (CFGI) for Hydrologic Response Unit 67 exceeded a value of 50 with the number of days that the minimum observed soil temperature was below freezing at a depth of 2 inches at the Soil Climate Analysis Network (SCAN) site, Lind, Washington site and the AgriMet site, Odessa, Washington, water years 1996-2012..

12. Graph showing annual mean runoff at Crab Creek at Irby, Washington

13. Shaded relief map showing elevation contours and locations of weather and streamflow-gaging stations used for input and calibration of the watershed model of Reynolds Creek, Idaho.

14. Graphs showing simulated and measured mean monthly runoff at three calibration sites in the Reynolds Creek Basin, Idaho, water years 1985-96.

15. Maps showing difference in days of snow-covered days minus frozen-ground days in the Columbia Plateau and Snake River Plain study areas, Idaho, Oregon, and Washington, water years 2002 and 2003.

16. Graph showing annual average number of days by pixel estimated from processed satellite remote sensing data to be either frozen or snow covered, Columbia Plateau, Idaho, Oregon, and Washington.

17. Graph showing annual average number of days by pixel estimated from processed satellite remote sensing data to be either frozen or snow covered, Snake River Plain, Idaho and Oregon.

18. Range plot showing simulated basin-averaged, annual mean daily maximum temperature for the upper Crab Creek, Columbia Plateau, Washington, water years 2008-94 


\section{Figures-Continued}

19. Range plot showing simulated basin-averaged, annual mean daily precipitation for the upper Crab Creek, Columbia Plateau, Washington, water years 2008-94 ................26

20. Range plot showing simulated basin-averaged, annual mean daily evapotranspiration for the upper Crab Creek, Columbia Plateau, Washington, water years 2008-94.

21. Range plot showing simulated basin-averaged, annual mean daily moisture movement from soil to groundwater and representative of recharge in the basin for the upper Crab Creek, Columbia Plateau, Washington, water years 2008-94 .....

22. Range plot for annual mean daily continuous frozen ground index for hydrologic response unit 67 for the upper Crab Creek, Columbia Plateau, Washington, water years 2008-94

23. Boxplots showing basin mean daily precipitation input to the Upper Crab Creek model for each month for three future periods averaged for five global circulation models and three emission scenarios

24. Boxplots for basin-averaged daily maximum air temperature input to the Upper Crab Creek model for three future periods averaged for five global circulation models and three emission scenarios

25. Boxplots for basin-averaged simulated daily soil moisture flow to groundwater that is output from the Upper Crab Creek model for three future periods averaged for five global circulation models and three emission scenarios

26. Maps showing simulated mean annual recharge and mean annual number of days when the continuous frozen ground index is greater than 50 for Reynolds Creek Basin, Snake River Plain, Idaho, for baseline, 2040, and 2080

27. Maps showing simulated mean daily snow-water equivalent and mean annual number of days of snow cover for Reynolds Creek Basin, Snake River Plain, Idaho, for baseline, 2040, and 2080

28. Maps showing simulated mean annual actual evapotranspiration and mean daily total soil moisture for Reynolds Creek Basin, Snake River Plain, Idaho, for baseline, 2040, and 2080

\section{Tables}

1 AgriMet and Soil Climate Analysis Network soil temperature monitoring sites and periods of frozen soil, Columbia Plateau and Snake River Plain study areas, Idaho, Oregon, and Washington, water years 1996-2010

2 Simulated future climate scenarios (2001-99) in the Columbia Plateau and Snake River Plain study areas, Idaho, Oregon, and Washington

3 Global Circulation Models used in the Columbia Plateau and Snake River Plain study areas, Idaho, Oregon, and Washington

4 Mean seasonal increases in air temperature from ensembles of $10 \mathrm{Global}$ Circulation Models for the SRESa1b emission scenario used in simulations for Reynolds Creek Basin, Idaho.

5 Projected change by year by linear regression model and the median of the yearto-year difference on the central tendencies of five Global Circulation Models for three emission scenarios for selected Precipitation Runoff Modeling System (PRMS) output variables, upper Crab Creek, Washington

6 Simulated recharge, Continuous Frozen Ground Index, snow-water equivalent, snow cover, actual evapotranspiration, runoff, and soil moisture for Reynolds Creek Basin, Snake River Plain, Idaho, for baseline, 2040, and 2080 model runs .. 


\section{Conversion Factors, Datums, and Abbreviations and Acronyms}

\section{Conversion Factors}

\begin{tabular}{|c|c|c|}
\hline Multiply & By & To obtain \\
\hline \multicolumn{3}{|c|}{ Length } \\
\hline inch (in.) & 2.54 & centimeter $(\mathrm{cm})$ \\
\hline foot $(\mathrm{ft})$ & 0.3048 & meter $(\mathrm{m})$ \\
\hline mile (mi) & 1.609 & kilometer (km) \\
\hline \multicolumn{3}{|c|}{ Area } \\
\hline acre & 0.4047 & hectare (ha) \\
\hline square mile $\left(\mathrm{mi}^{2}\right)$ & 2.590 & square kilometer $\left(\mathrm{km}^{2}\right)$ \\
\hline \multicolumn{3}{|c|}{ Flow rate } \\
\hline cubic foot per second $\left(\mathrm{ft}^{3} / \mathrm{s}\right)$ & 0.02832 & cubic meter per second $\left(\mathrm{m}^{3} / \mathrm{s}\right)$ \\
\hline \multicolumn{3}{|l|}{ SI to Inch/Pound } \\
\hline Multiply & By & To obtain \\
\hline \multicolumn{3}{|c|}{ Length } \\
\hline centimeter $(\mathrm{cm})$ & 0.3937 & inch (in.) \\
\hline millimeter (mm) & 0.03937 & inch (in.) \\
\hline meter $(\mathrm{m})$ & 3.281 & foot $(\mathrm{ft})$ \\
\hline kilometer (km) & 0.6214 & mile (mi) \\
\hline \multicolumn{3}{|c|}{ Area } \\
\hline hectare (ha) & 2.471 & acre \\
\hline \multicolumn{3}{|c|}{ Flow rate } \\
\hline cubic meter per second $\left(\mathrm{m}^{3} / \mathrm{s}\right)$ & 35.31 & cubic foot per second $\left(\mathrm{ft}^{3} / \mathrm{s}\right)$ \\
\hline
\end{tabular}

Temperature in degrees Fahrenheit $\left({ }^{\circ} \mathrm{F}\right)$ may be converted to degrees Celsius $\left({ }^{\circ} \mathrm{C}\right)$ as follows:

$$
{ }^{\circ} \mathrm{C}=\left({ }^{\circ} \mathrm{F}-32\right) / 1.8 \text {. }
$$

\section{Datums}

Vertical coordinate information is referenced to the North American Vertical Datum of 1988 (NAVD 88).

Horizontal coordinate information is referenced to the North American Datum of 1983 (NAD 83).

Elevation, as used in this report, refers to distance above the vertical datum. 


\section{Conversion Factors, Datums, and Abbreviations and Acronyms-Continued}

\section{Abbreviations and Acronyms}

\begin{tabular}{ll}
\hline AET & actual evapotranspiration \\
CBP & Columbia Basin Project \\
CFGI & Continuous Frozen Ground Index \\
DMSP & Defense Meteorological satellite program \\
GCM & Global Circulation Model \\
GHz & Gigahertz \\
GIS & Geographic Information System \\
HRU & Hydrologic response units \\
NRCS & Natural Resources Conservation Service \\
NSIDC & National Snow and Ice Data Center \\
PET & potential evapotranspiration \\
PRMS & Precipitation Runoff Modeling System \\
RASA & Regional Aquifer-System Analysis \\
Reclamation & Bureau of Reclamation \\
SCAN & Soil Climate Analysis Network \\
SSMI & Special Sensor Microwave Imager \\
USDA & U.S. Department of Agriculture \\
USGS & U.S. Geological Survey \\
WYD & water-year day \\
\hline
\end{tabular}





\title{
Monitoring Recharge in Areas of Seasonally Frozen Ground in the Columbia Plateau and Snake River Plain, Idaho, Oregon, and Washington
}

\author{
By Mark Mastin and Edward Josberger
}

\section{Abstract}

Seasonally frozen ground occurs over approximately one-third of the contiguous United States, causing increased winter runoff. Frozen ground generally rejects potential groundwater recharge. Nearly all recharge from precipitation in semi-arid regions such as the Columbia Plateau and the Snake River Plain in Idaho, Oregon, and Washington, occurs between October and March, when precipitation is most abundant and seasonally frozen ground is commonplace. The temporal and spatial distribution of frozen ground is expected to change as the climate warms. It is difficult to predict the distribution of frozen ground, however, because of the complex ways ground freezes and the way that snow cover thermally insulates soil, by keeping it frozen longer than it would be if it was not snow covered or, more commonly, keeping the soil thawed during freezing weather.

A combination of satellite remote sensing and ground truth measurements was used with some success to investigate seasonally frozen ground at local to regional scales. The frozen-ground/snow-cover algorithm from the National Snow and Ice Data Center, combined with the 21-year record of passive microwave observations from the Special Sensor Microwave Imager onboard a Defense Meteorological Satellite Program satellite, provided a unique time series of frozen ground. Periodically repeating this methodology and analyzing for trends can be a means to monitor possible regional changes to frozen ground that could occur with a warming climate.

The Precipitation-Runoff Modeling System watershed model constructed for the upper Crab Creek Basin in the Columbia Plateau and Reynolds Creek basin on the eastern side of the Snake River Plain simulated recharge and frozen ground for several future climate scenarios. Frozen ground was simulated with the Continuous Frozen Ground Index, which is influenced by air temperature and snow cover. Model simulation results showed a decreased occurrence of frozen ground that coincided with increased temperatures in the future climate scenarios. Snow cover decreased in the future climate scenarios coincident with the temperature increases. Although annual precipitation was greater in future climate scenarios, thereby increasing the amount of water available for recharge over current (baseline) simulations, actual evapotranspiration also increased and reduced the amount of water available for recharge over baseline simulations. The upper Crab Creek model shows no significant trend in the rates of recharge in future scenarios. In these scenarios, annual precipitation is greater than the baseline averages, offsetting the effects of greater evapotranspiration in future scenarios. In the Reynolds Creek Basin simulations, precipitation was held constant in future scenarios and recharge was reduced by 1.0 percent for simulations representing average conditions in 2040 and reduced by 4.3 percent for simulations representing average conditions in 2080. The focus of the results of future scenarios for the Reynolds Creek Basin was the spatial components of selected hydrologic variables for this 92 square mile mountainous basin with 3,600 feet of relief. Simulation results from the watershed model using the Continuous Frozen Ground Index provided a relative measure of change in frozen ground, but could not identify the within-soil processes that allow or reject available water to recharge aquifers. The model provided a means to estimate what might occur in the future under prescribed climate scenarios, but more detailed energybalance models of frozen-ground hydrology are needed to accurately simulate recharge under seasonally frozen ground and provide a better understanding of how changes in climate may alter infiltration.

\section{Introduction}

Seasonally frozen ground occurs over about one-third of the contiguous United States (Zhang and others, 2003), and increased winter runoff resulting from frozen ground has been well-documented (Zuzel and Pikul, 1987; Shanley and Chalmers, 1999). A corresponding decrease in groundwater recharge can be expected in these areas because frozen ground generally rejects potential recharge. In semi-arid regions such 
as the Columbia Plateau and the Snake River Plain in the Pacific Northwest (Idaho, Oregon, and Washington), nearly all recharge from precipitation occurs between October and March, when precipitation is most abundant, and either transient or seasonally frozen ground is commonplace. Infiltration into seasonally frozen soils involves coupled heat and mass transfer that is affected by many factors, such as the thermal properties of the soil, soil temperature, soil moisture content, and either the presence or absence of macropores (Granger and others, 1984; Gray and others, 2001). The rate of infiltration for frozen soils can be about an order of magnitude less than the same unfrozen soil (Engelmark, 1988). The insulating properties of a seasonal snow cover must also be considered because it generally raises the mean annual soil temperature (Goodrich, 1982). Timing of snowfall can be important; an early snow cover that remains all year will result in less soil freezing than a late snow cover that falls after a period of cold weather (Cherkauer and Lettenmaier, 1999).

The regional and hemispheric extent of frozen ground has decreased in recent years. The estimated maximum extent of frozen ground in the Northern Hemisphere has decreased by 7 percent from 1901 through 2002, and the timing of surface thaw and subsequent initiation of the growing season over North America has advanced by about 8 days from 1988 to 2001 (Zhang and Armstrong, 2008) and for the pan-Arctic basin and Alaska (McDonald and others, 2004).

Satellite remote sensing and ground truth measurements have been used to investigate seasonally frozen ground at local to regional scales with some success. Data from passive microwave sensors such as the Scanning Multi-channel Microwave Radiometer (SMMR; 1978-87) and the Special Sensor Microwave Imager (SSM/I; 1987-present [2013]) can be used to detect surface soil freeze or thaw. Advantages of using these sensors are continuity and coverage, all-weather capability, and frequent repeat time (every other day or twice daily) that ensure detection of temporal and spatial variations of surface soil freeze and thaw. A disadvantage is relatively low-resolution data of about $16-19 \mathrm{mi}$; however, this scale is not inappropriate for evaluating groundwater recharge from ambient precipitation. The more recent Advanced Microwave Scanning Radiometer-Earth Observing System, launched in 2002, has lower-frequency channels and higher resolution, which may be superior for detecting soil freeze/thaw cycles. Multiple algorithms using passive microwave data are available, and they generally perform well for identifying snow-free frozen ground from snow-covered ground and ground above freezing. These features are not likely to be problematic for recharge studies because near-surface soils over the contiguous United States generally freeze before they are snow covered or not at all (Zhang and Armstrong, 2001), and because soils that freeze when relatively wet potentially reject recharge on a more consistent basis than soils that freeze when dry. Overall, the identification of frozen ground using passive microwave data shows great potential for providing insight into climate change effects on the extent, frequency, and duration of frozen ground, and the subsequent influence of frozen ground on groundwater recharge. Combined with existing precipitation-runoff algorithms to estimate recharge during either frozen or thawedground episodes, a monitoring strategy to track changes in groundwater recharge attributable to climate change effects on seasonally frozen ground may be feasible.

\section{Purpose and Scope}

The purpose of the project is to (1) provide proof of concept of a methodology to monitor seasonally frozen ground in large regions of the Pacific Northwest; (2) look for current and possible future trends in the amount of area and duration of frozen ground; and (3) investigate the linkage between seasonally frozen ground, climate change, and groundwater recharge. This report describes the study area, the remote-sensing techniques used to monitor frozen ground, the method and results from trend analysis, and possible outcomes in future warmer climates.

\section{Study Area}

The study area consists of two regions overlying large regional aquifers in the Pacific Northwest. The Columbia Plateau occupies about 50,600 $\mathrm{mi}^{2}$ and lies in southeastern Washington, and extends south into northeast Oregon and east into Idaho near Lewiston (fig. 1). The Snake River Plain surrounds the middle part of the Snake River in southern Idaho, spanning Idaho from Idaho Falls at the eastern end to Boise on the northwestern end, with a small area extending into Oregon near Boise (ig. 2). Both regional aquifers are in areas drained by the Columbia River and its tributaries. With the exception of the urban areas around Spokane on the eastern border of the Columbia Plateau and around Boise on the northwestern area of the Snake River Plain, the regions are generally sparsely populated, but are important agricultural areas with mixtures of dryland and irrigated farms. Large pumping systems along the Snake and Columbia Rivers, surface-water diversion from other rivers and streams, and wells provide irrigation water to the lands in the region. Much of the area is dry, with mean annual precipitation (1971-2000 normal) of 17.86 in. for the Columbia Plateau aquifer and 10.92 in. for the Snake River Plain (fig. 3). The higher mean for the Columbia Plateau aquifer comes from some areas of greater than 100 in. per year along the eastern flank of the Cascade Mountain Range and the western edge of the Columbia Plateau aquifer. 


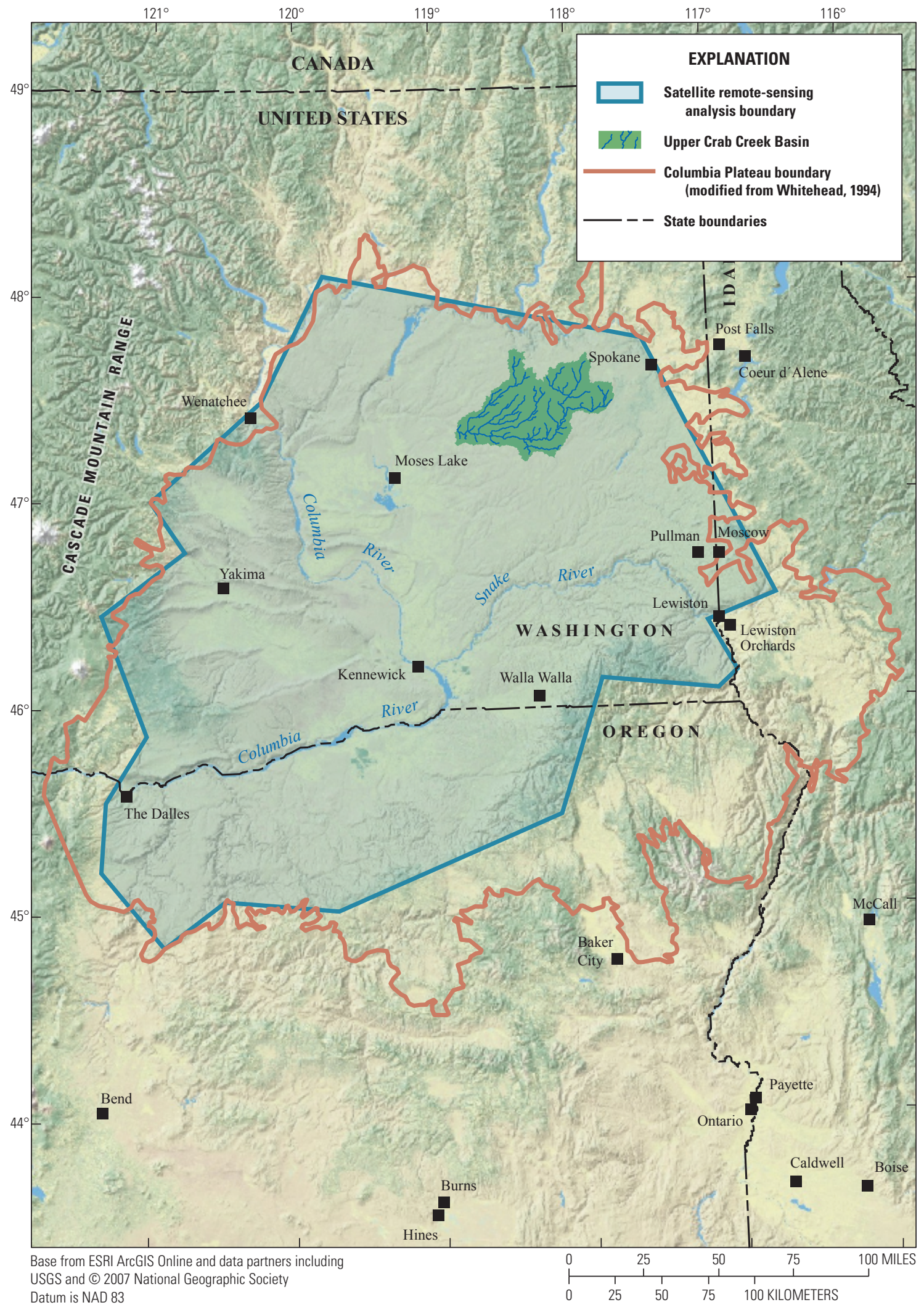

Figure 1. Satellite remote-sensing and Columbia Plateau boundaries, Idaho, Oregon, and Washington. 


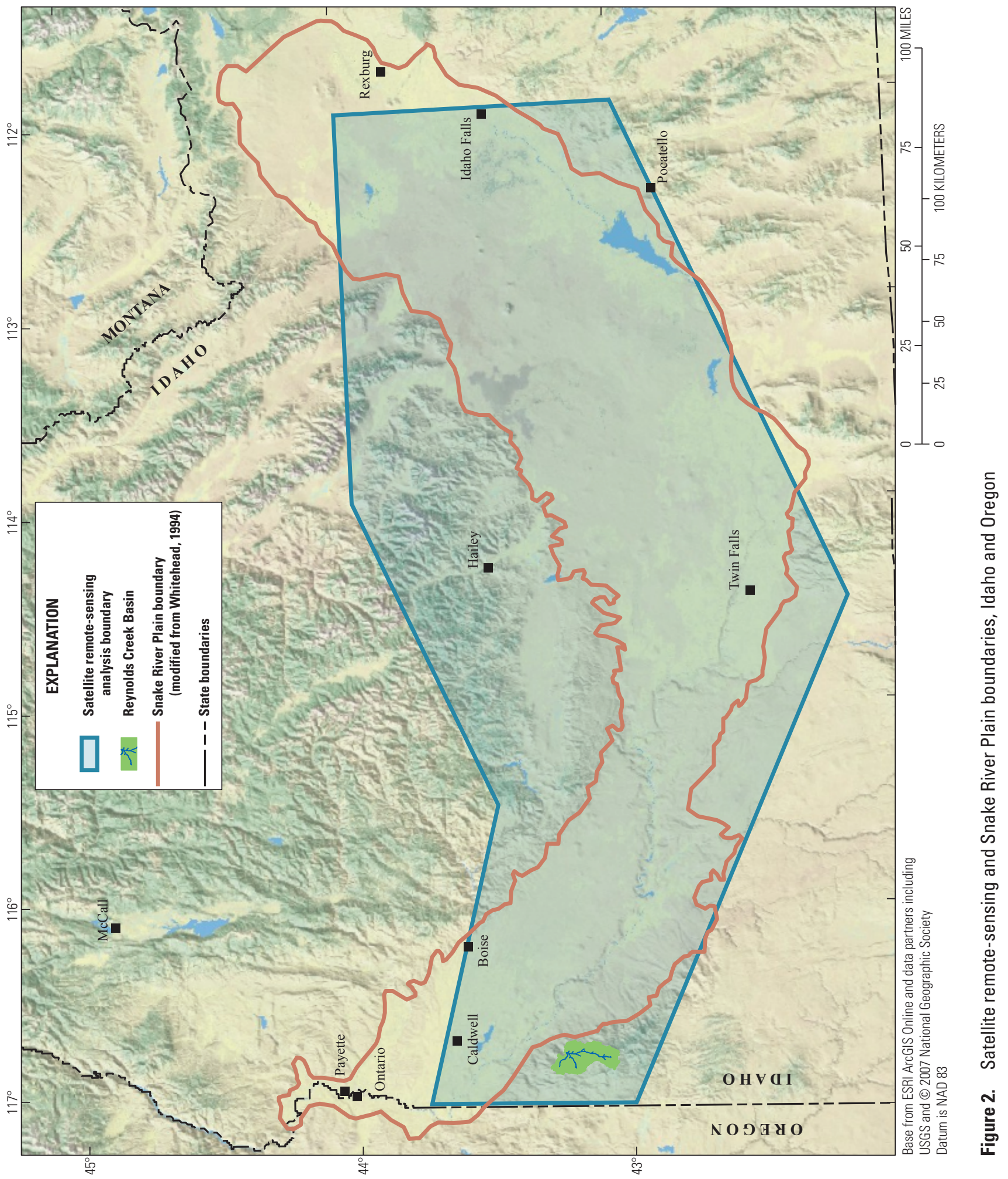




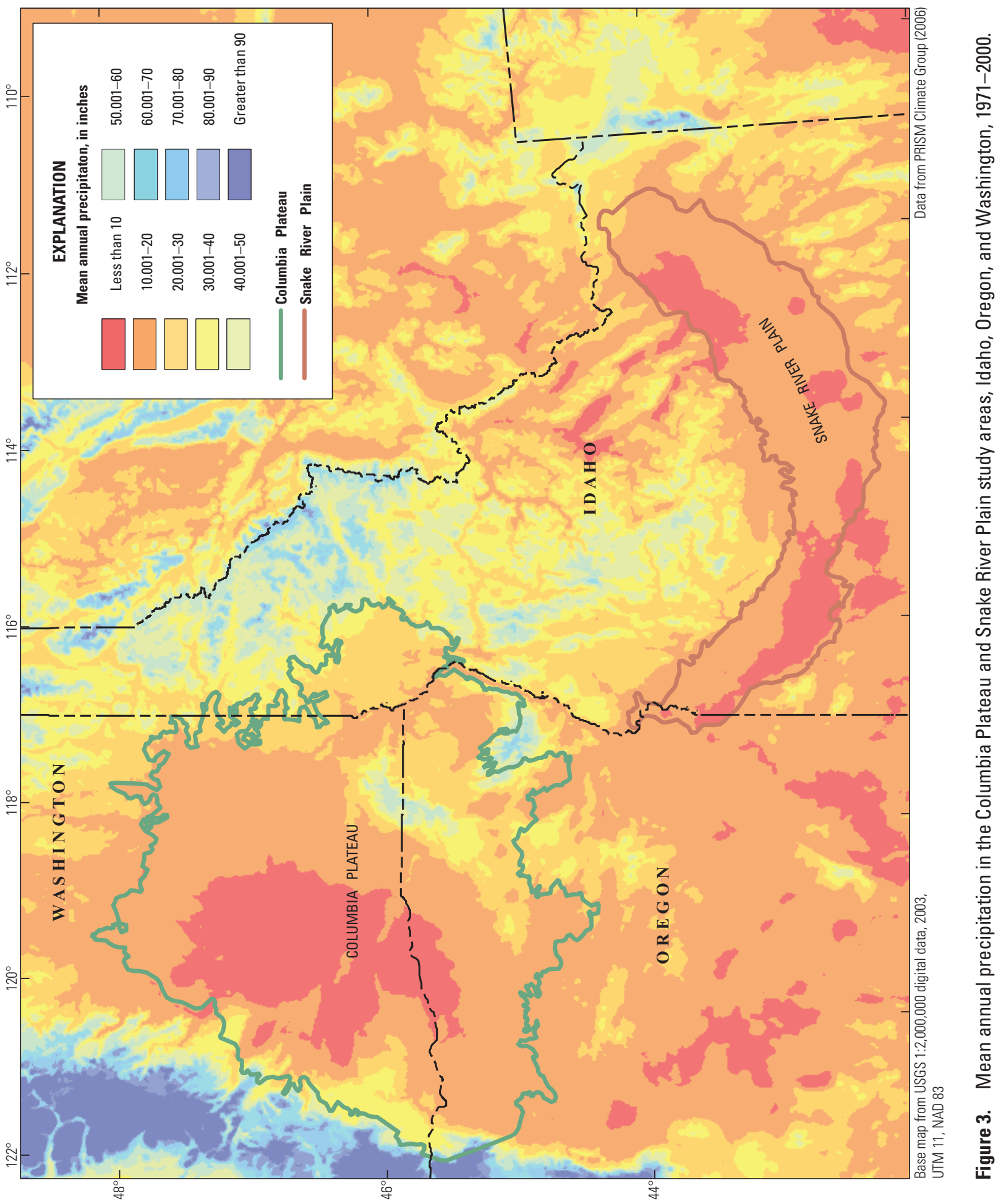


Recharge from precipitation in the Columbia Plateau has been estimated at an average rate of $6,570 \mathrm{ft}^{3} / \mathrm{s}$ or $2.72 \mathrm{in} / \mathrm{yr}$ for predevelopment land-use conditions, plus $555 \mathrm{ft}^{3} / \mathrm{s}$ or $0.15 \mathrm{in} / \mathrm{yr}$ recharge from rivers. For development conditions (averaged for 1983-85), estimate of recharge is $10,205 \mathrm{ft}^{3} / \mathrm{s}$ or $4.24 \mathrm{in} / \mathrm{yr}$ from precipitation and irrigation. During that same period, pumpage was estimated at $1,144 \mathrm{ft}^{3} / \mathrm{s}$, of which 90 percent was used for irrigation (Hansen and others, 1994). The area of irrigated cropland in the Columbia Plateau was $500,000 \mathrm{mi}^{2}$ during the 1983-85 period with 75 percent of the irrigated cropland supplied by surface water, mainly from the Columbia and Yakima Rivers. Dryland crops covered about $12,000 \mathrm{mi}^{2}$ in the Columbia Plateau with $5,000-7,000 \mathrm{mi}^{2}$ of sagebrush and grasslands.

The U.S. Geological Survey (USGS) Regional Aquifer-System Analysis (RASA) divided the Snake River Plain (total area of 15,600 $\mathrm{mi}^{2}$ ) based on its geological composition into an eastern plain $\left(10,800 \mathrm{mi}^{2}\right)$ occupying a downwarp filled with Quaternary basalt, and a western plain $\left(4,800 \mathrm{mi}^{2}\right)$ underlain with sedimentary rocks (Lindholm, 1996). Recharge in the Snake River Plain has been estimated for the eastern plain at a rate of $1.32 \mathrm{in} / \mathrm{yr}$ from direct precipitation for water year (WY; a water year begins October 1 of the previous calendar year and ends September 30) 1980 in the eastern two-thirds of the aquifer (Garabedian, 1986); however, this was only 9 percent of the total recharge calculated by Garabedian (1986), which included recharge from surface-water irrigation (60 percent), Snake River loss (10 percent), tributary stream and canal losses (6 percent), and tributary valley underflow (15 percent).

Seasonably frozen soil conditions occur in the two regions. Some soils in the regions may not freeze at all in a particular year, and the start and end dates of frozen soils vary considerably annually and spatially. The spatial context includes latitude, longitude, and the depth of frost within the soil. The depth and duration of frost in the soils is dependent on "magnitude and duration of subfreezing air temperatures, soil water, snow depth, soil type, and vegetation cover as well as slope and aspect" (Burton and others, 1990, p. 140). Measurements of soil temperatures in the study areas illustrate some of this temporal and spatial variation in frozen soils. Soil temperature and meteorological data were collected in the region at a network of AgriMet sites.
AgriMet is a satellite-based network of automated agricultural weather stations throughout the Pacific Northwest operated and maintained by the Bureau of Reclamation (Bureau of Reclamation, 2012). Soil temperature was collected at various depths, typically at 2-, 4-, 8-, 20-, and 40-in. Complete years of data generally begin about WY 1996; data at the 4-in. soil depth are the most complete with the longest record of soil temperature for the sites in the study area (table 1). Two U.S. Department of Agriculture, Natural Conservation Service Soil Climate Analysis Network sites (U.S. Department of Agriculture, 2009) also are in the regions and their data were added to the analysis of the AgriMet sites shown in table 1. Generally, the more easterly stations have the highest number of frozen soil days in the water year, earliest frozen day, and highest percentage of years with frozen soil (fig. 4).

The hydrologic effects of frozen soils in the study areas can be illustrated with discharge hydrographs of the runoff response of two storms in the upper Crab Creek basin in the Columbia Plateau. At streamflow gaging station Crab Creek at Irby, Washington (12465000), the peak-of-record discharge during WY 1957 and a peak discharge during WY 2004 occurred in February of each water year. About the same amount of rain fell 2 days prior to both peaks. Descriptions of the basin conditions for the 1957 peak included air temperatures that never exceeded $32{ }^{\circ} \mathrm{F}$ for 1 week prior to the peak discharge and the ground frozen solid before the peak (Bureau of Reclamation, written commun., September 25, 1957). Snow-water equivalent in the snow pack that was mostly melted during both floods was estimated to be about twice the amount in 2004 as it was in 1957 prior to the flood. Air temperatures were relatively warm in February 2004, and an existing snowpack insulated the soils so they were above freezing (Mastin, 2009). The frozen soils in 1957 impeded infiltration so all the available water became surface runoff that generated an instantaneous peak discharge of $8,370 \mathrm{ft}^{3} / \mathrm{s}$, which is the peak of record for the gaging station Crab Creek at Irby (in operation since 1942). Despite having a similar rainfall input as the 1957 flood and even more snowmelt input, the same basin produced an instantaneous peak discharge of only $380 \mathrm{ft}^{3} / \mathrm{s}$. Presumably, most of the water available for runoff infiltrated the soil, and less water ran off the land as surface runoff (fig. 5). This increase in infiltration would have increased soil moisture and therefore increased the potential for recharge to aquifers. 
Table 1. AgriMet and Soil Climate Analysis Network soil temperature monitoring sites and periods of frozen soil, Columbia Plateau and Snake River Plain study areas, Idaho, Oregon, and Washington, water years 1996-2010.

[AgriMet data from Bureau of Reclamation (2012). Soil Climate Analysis Network (SCAN) data from U.S. Department of Agriculture (2009). WY day: Consecutive day number of the water year beginning with 1 for October 1. Abbreviation:-, no data]

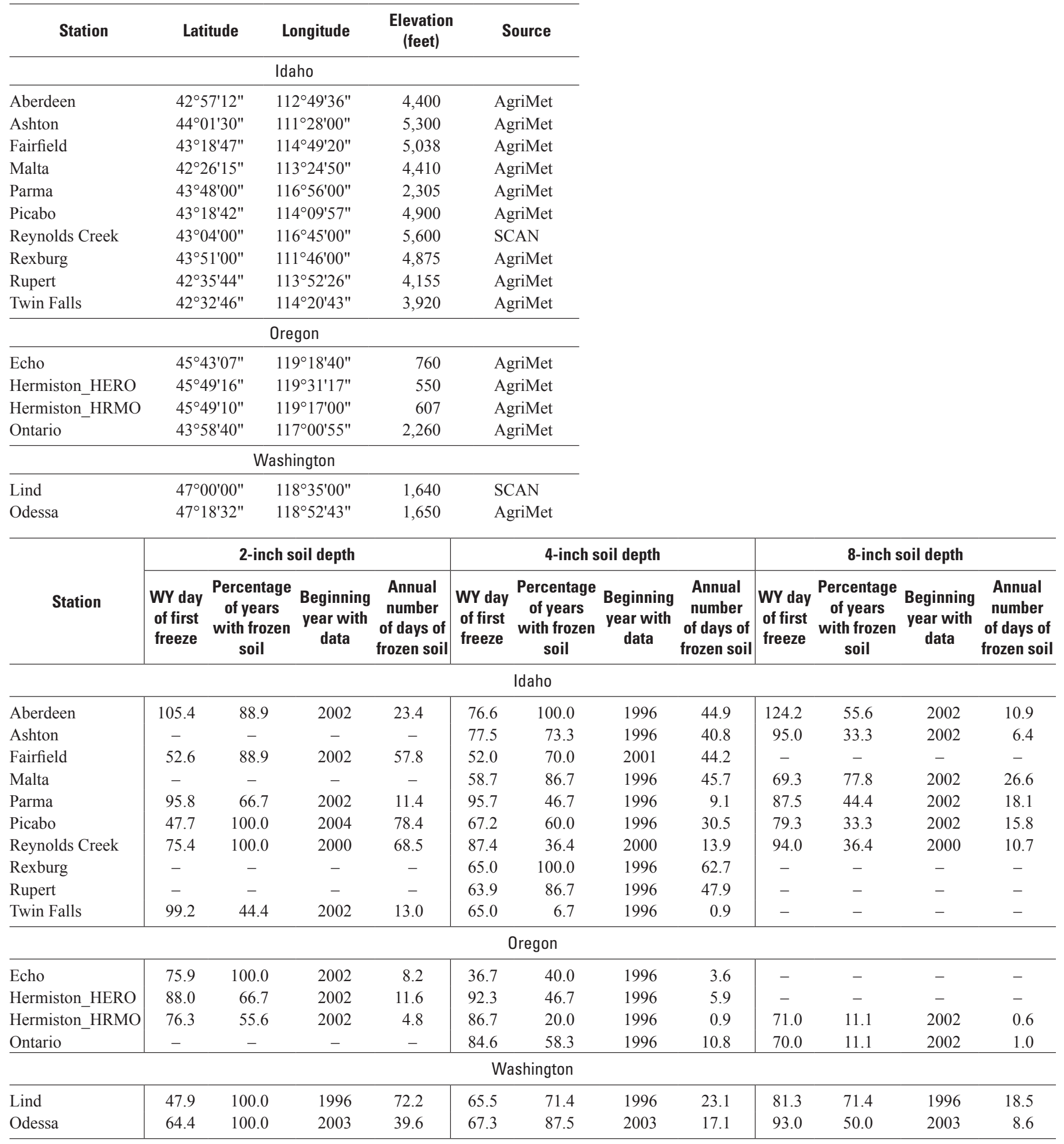




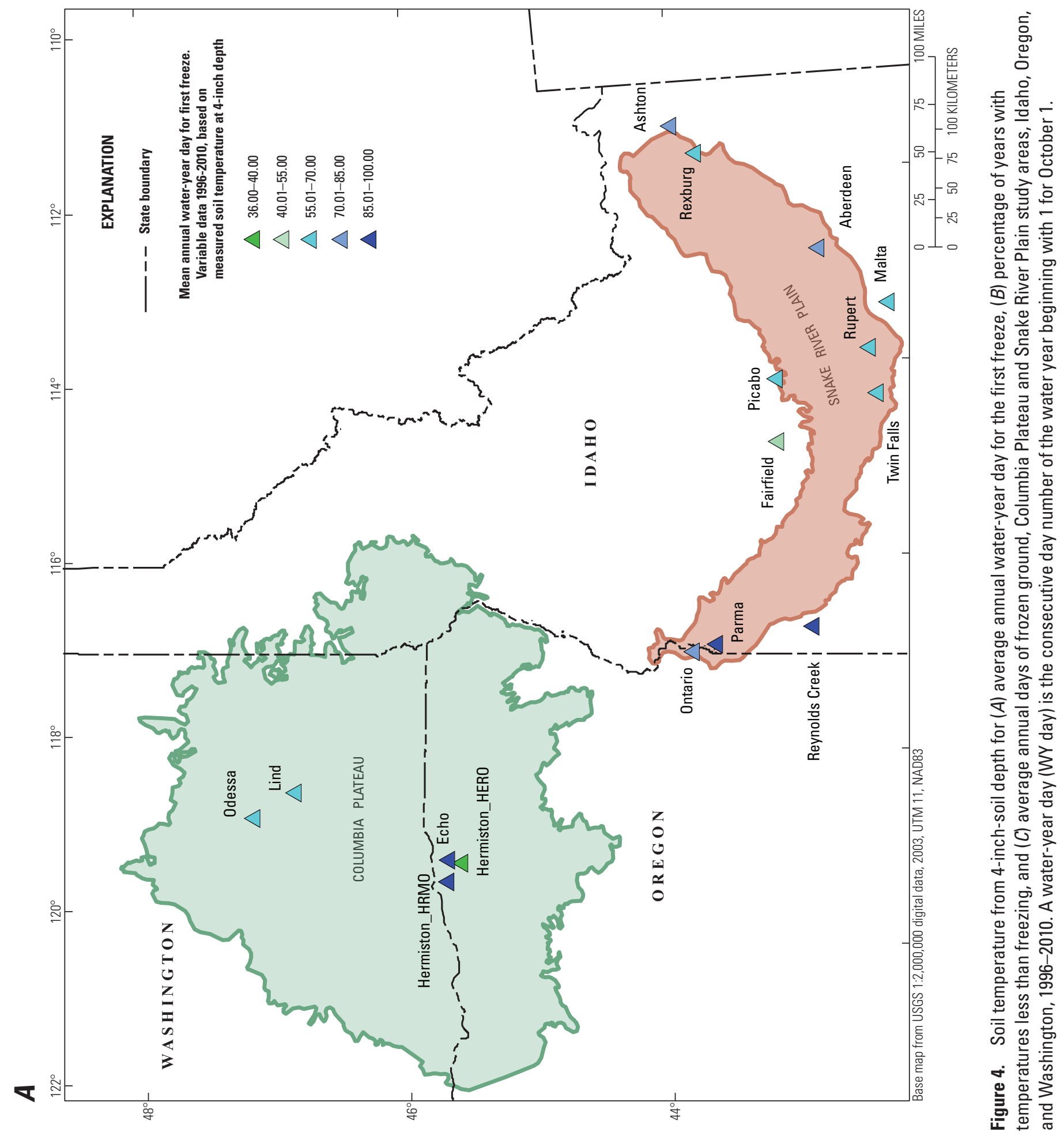




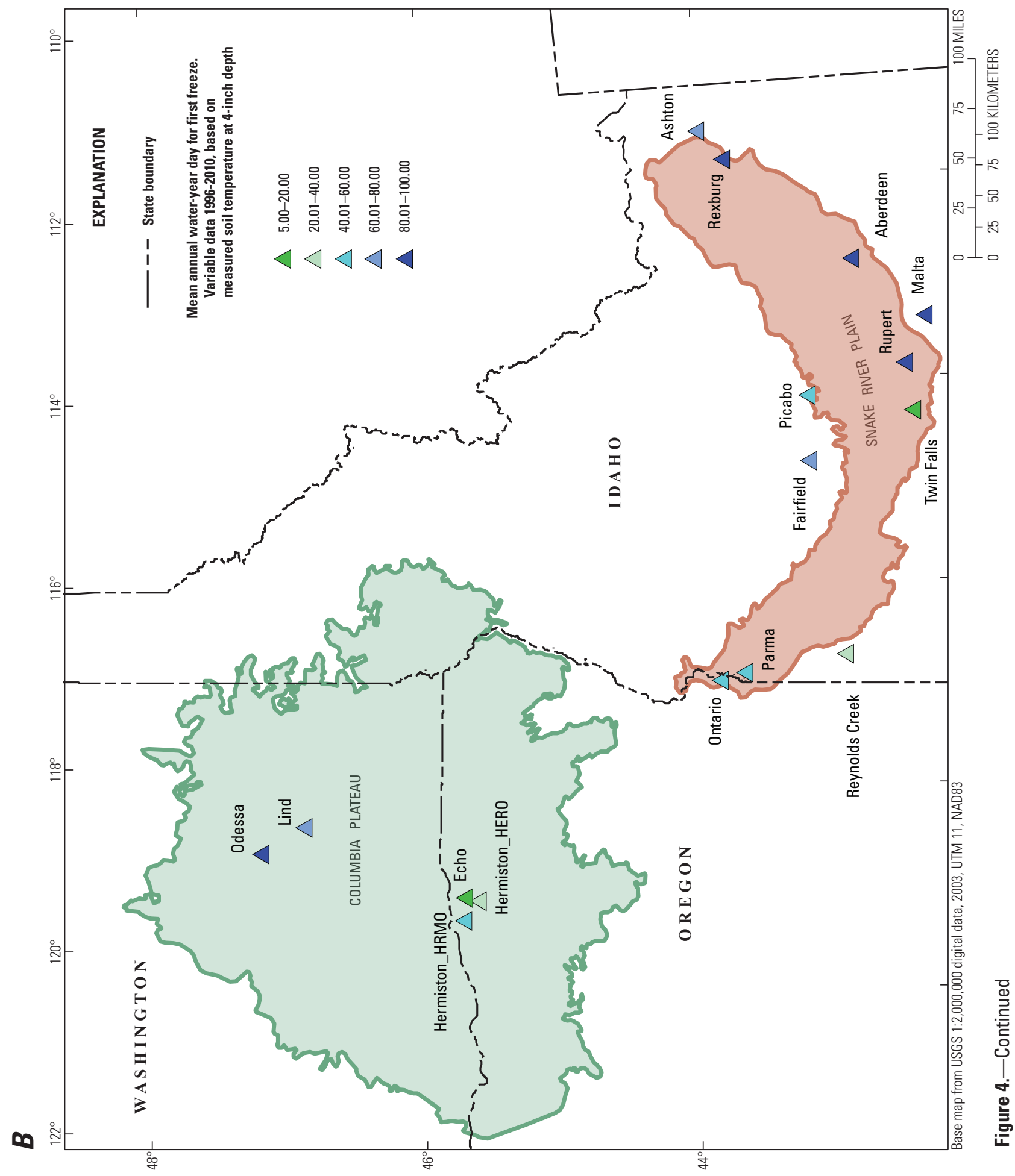




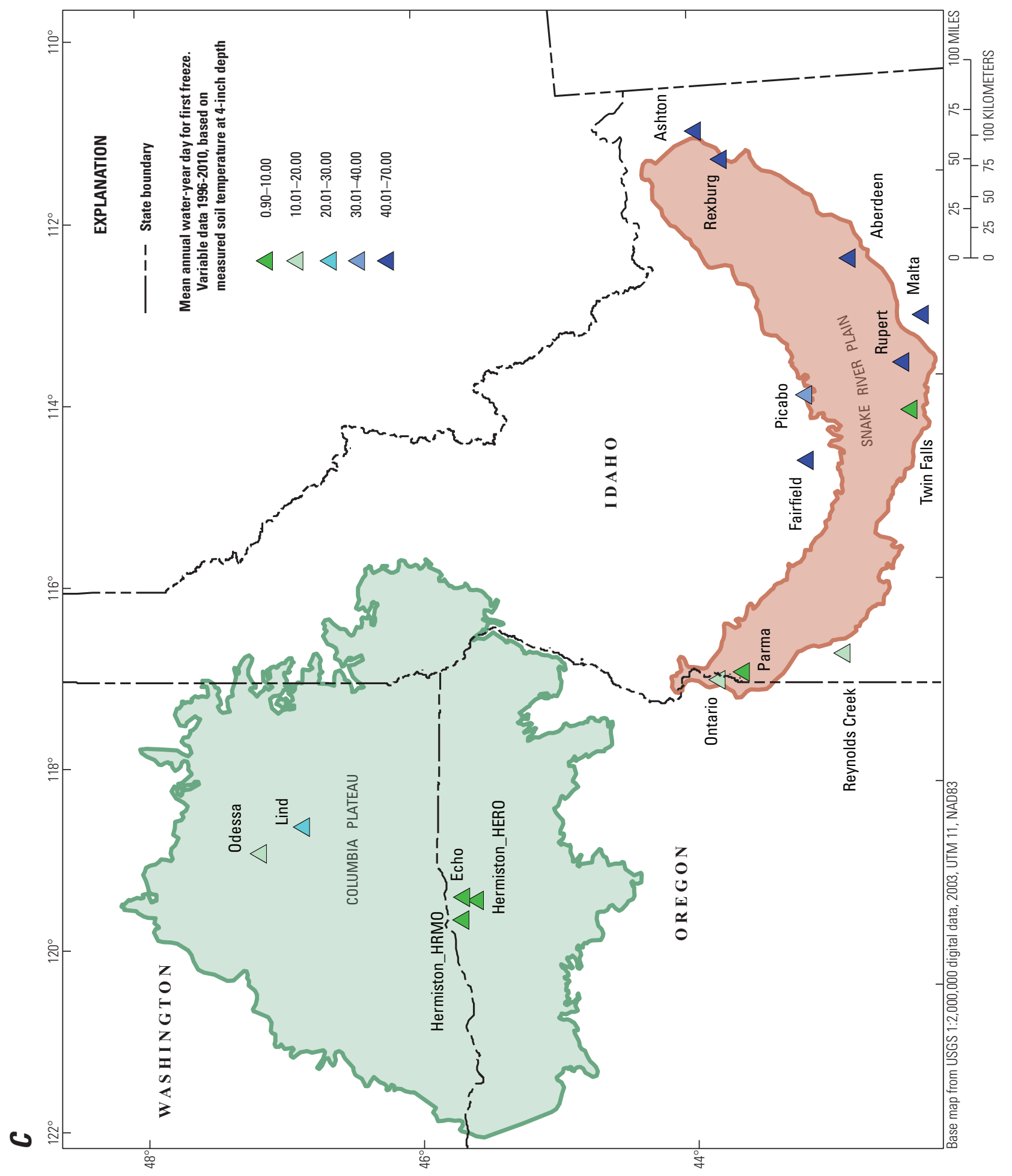

பํ. 

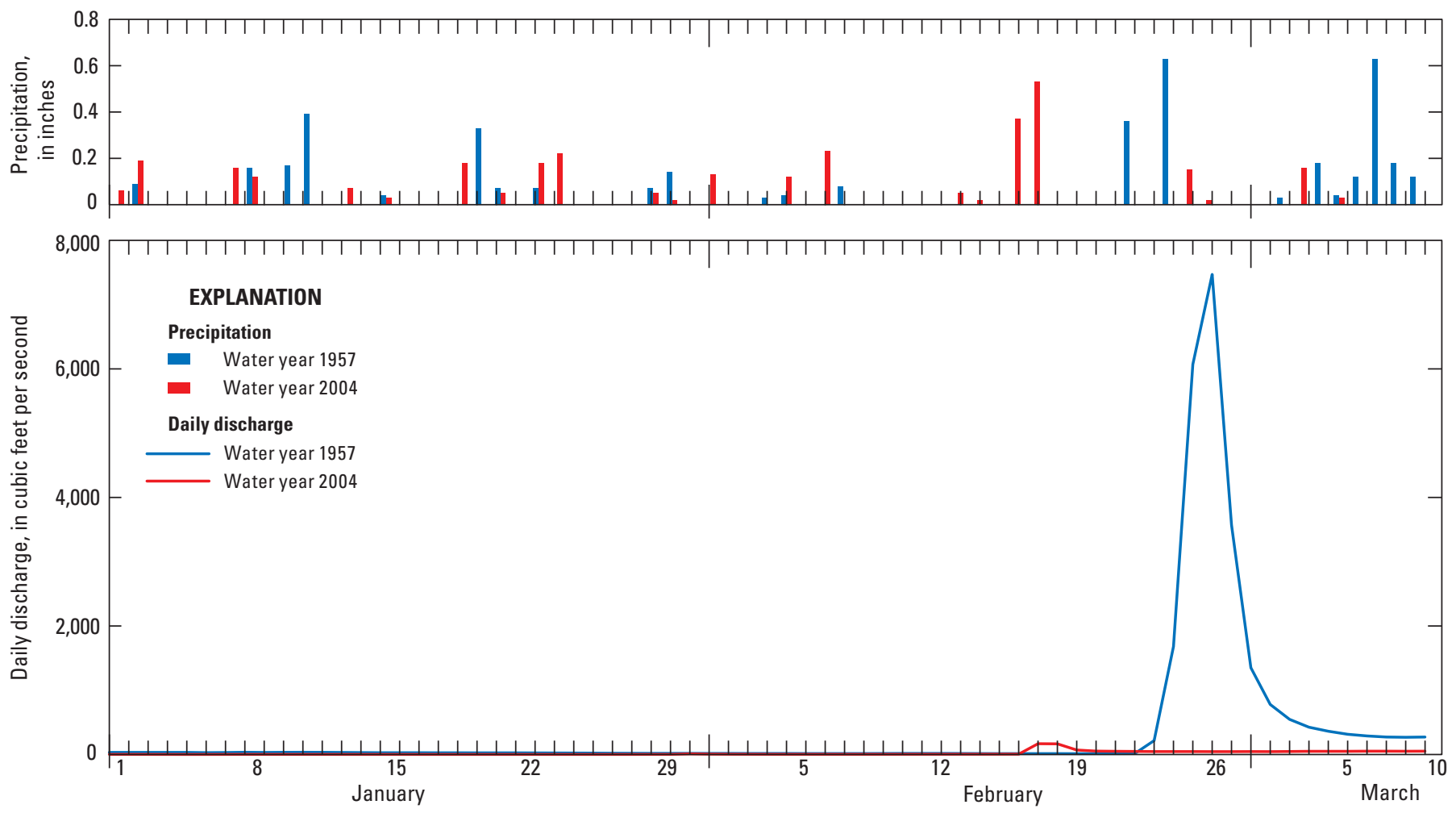

Figure 5. Precipitation and daily discharge for U.S. Geological Survey streamflow-gaging station Crab Creek at Irby, Washington, January 1 to March 9, water years 1957 and 2004.

\section{Approach}

Two lines of investigation were made during this project. First, available satellite remote data were examined and processed to illustrate a methodology and provide a proof of concept to monitor large regional aquifers for frozen ground over multiple decades. Second, watershed modeling provided a method to examine how frozen ground can affect recharge at the scale of small basins in the study areas, how frozen ground and recharge relations might change under future emission scenarios and changing climate estimates, and how frozen ground and recharge can vary spatially in a small basin. The approach to watershed modeling and analyzing how a changing climate may affect recharge involved the same watershed model, but was different in each of the two basins. For the Crab Creek Basin, a continuous long-term time series of hydrologic variables related to recharge were generated into the future under several scenarios to investigate for possible trends in the variables. For the Reynolds Creek Basin, a basin with large relief, the focus was on the spatial distribution of these hydrologic variables and comparing the results of future simulations at two discrete time periods. Besides providing information on possible future trends in recharge (objective 2 in the section "Purpose and Scope"), the model simulation results also show how seasonally frozen ground, climate change, and groundwater recharge interact with one another (objective 3 in section "Purpose and Scope").

\section{Satellite Remote Sensing}

Multi-frequency passive microwave observations from sensors carried by satellites have a proven capability to measure critical cryospheric parameters such as sea ice, snow, and frozen ground. Microwave observations are independent of solar illumination and cloud cover, which when combined with a multi-decade record makes them a powerful tool for hydrologic studies. Zhang and Armstrong (2001) developed an algorithm that used the 19 and 37 gigahertz $(\mathrm{GHz})$ brightness temperatures to determine the state of the ground: bare, bare and frozen, or snow covered. In this study, the passive microwave observations from the Special Sensor Microwave Imager (SSMI) were used, which is part of the Defense Meteorological satellite program (DMSP). The data were supplied by the National Snow and Ice Data Center (NSIDC) in Equal-Area Scalable Earth Grid format; each pixel was $15.5 \times 15.5 \mathrm{mi}$. The period of record used in this study spanned 21 years, 1989-2009. 


\section{Data Preparation}

The SSMI instrument has a swath width of $1,700 \mathrm{~km}$ with morning and evening equator crossings. The morning data were used to minimize temperature effects, warming and melting. At the latitude range of the study areas, $42^{\circ}-48^{\circ} \mathrm{N}$, the swath width results in a gap in the daily record of approximately 1 day, every 3 or 4 days. To facilitate the analysis of the 21-year-long record, data gaps in the time series were filled using a nearest neighbor approach; the missing value was assigned that of the subsequent day or, in the rare case of 2 days of missing value, was assigned to be that of the preceding day. This resulted in a data cube with no missing data that spanned 21 years for brightness temperatures or, with the application of the algorithm, the thermal state of the ground. These data were analyzed using Interactive Data Language code supplied by NSIDC, which was customized for this study.

The state of the ground for two regions in the Pacific Northwest, the Columbia Plateau and the Snake River Plain was examined during this study. The Colombia Plateau is

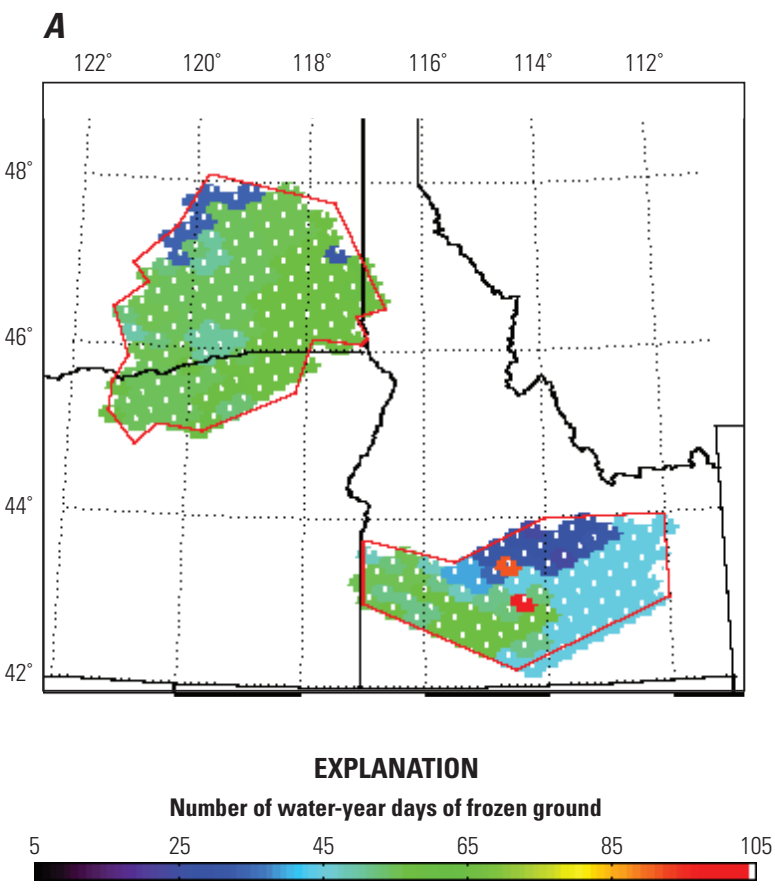

primarily in southeastern Washington and is captured in 129 pixels from a single SSMI image; the Snake River plain is across southern Idaho and is contained within 90 pixels. The location of each region and a sample of some data generated for this study are shown in figure 6. The pixels are color coded corresponding to the values in the color-bar and indicate the number of days that each pixel was classified as being frozen (fig 6A) and the number of days a pixel was classified as being snow covered (fig $6 B$ ) for WY 2006. Maps for the period of record are available in appendix A.

Satellite estimates of frozen ground were compared with records of frozen ground at several soil temperature stations throughout the Snake River Plain and Colombia Plateau. An example comparison from a selected site in the Snake River Plain is shown in figure 7. The stations are part of the regional Soil Climate Analysis Network (SCAN) and AgriMet networks sponsored by the U.S. Department of Agriculture (USDA) Natural Resources Conservation Service (NRCS) National Water and Climate Center and the Bureau of Reclamation (Reclamation), respectively.

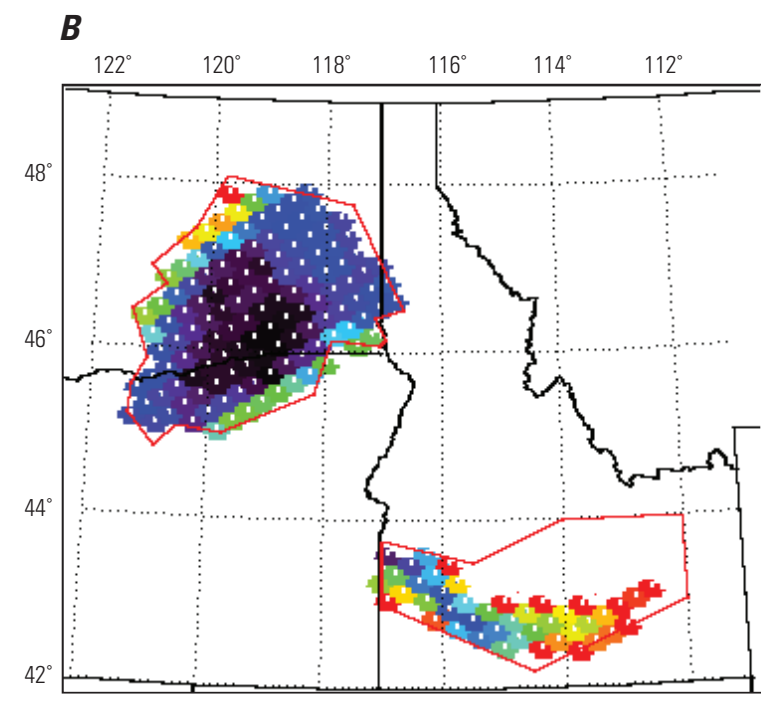

EXPLANATION

Number of water-year days of snow cover

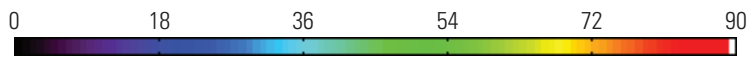

Figure 6. Satellite remote sensing data for $(A)$ frozen ground and $(B)$ snow cover, Columbia Plateau and Snake River Plain study areas, Idaho, Oregon, and Washington, water year 2006. 


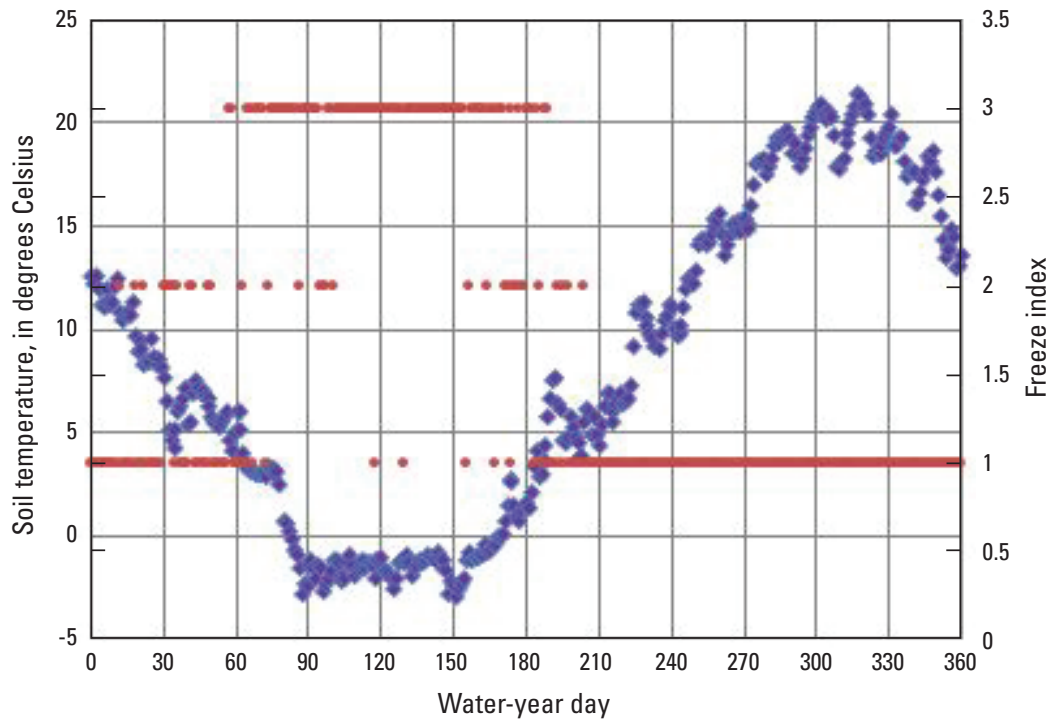

EXPLANATION

- Daily measured soil temperatures at the four-inch depth

- Satellite determined thermal state of the soil or Freeze index:

1-bare soil

2-bare and frozen soil

3-snowcovered

Figure 7. Soil temperature from direct measurements and satellite data for an AgriMet site at Picabo, Idaho, water year 1996. A water-year day is the consecutive day number of the water year beginning with 1 for October 1.

The 4-in. depth soil temperature and satellite-determined thermal state data compare well despite a couple of disparities (fig. 7). The first disparity is the difference between the observational scale of the satellite sensor $\left(15.5 \mathrm{mi}^{2}\right)$ and the point temperature made at the station. Second, the satellite is measuring the electromagnetic properties of the top $0.4 \mathrm{in}$, whereas the 4-in. depth temperature is buffered by a thick snow depth. These disparities also explain the sporadic occurrence of frozen ground prior to that indicated by the soil temperature.

One goal of this investigation is to determine the length of time, if any, between the occurrence of frozen ground and the subsequent time of snow cover. The satellite remote sensing data indicate that the progression through the thermal states does not proceed in an orderly fashion; instead, progression is intermittent and highly variable. Therefore, it is difficult to extract this information with a deterministic search through a pixel time series for the occurrence of frozen ground. Instead, we used a statistical technique developed by Rodionov (2004) that he used to examine time series of atmospheric variables, such as the Pacific Decadal Oscillation, for regime shifts. In this sequential technique, a test is performed as each new observation is included, to determine if there is a statistical difference, according to the Student t-test, between the two regimes. An example of the sequential technique for a site in the central area of the Snake River Plain for water year 1991 is shown in figure 8. There is a shift from bare to frozen on water-year day (WYD) 57 followed by a shift from frozen ground to snow-covered ground on WYD 72. In this case, there were 15 days of frozen ground before it became snow covered, and snow season ended on WYD 179. 


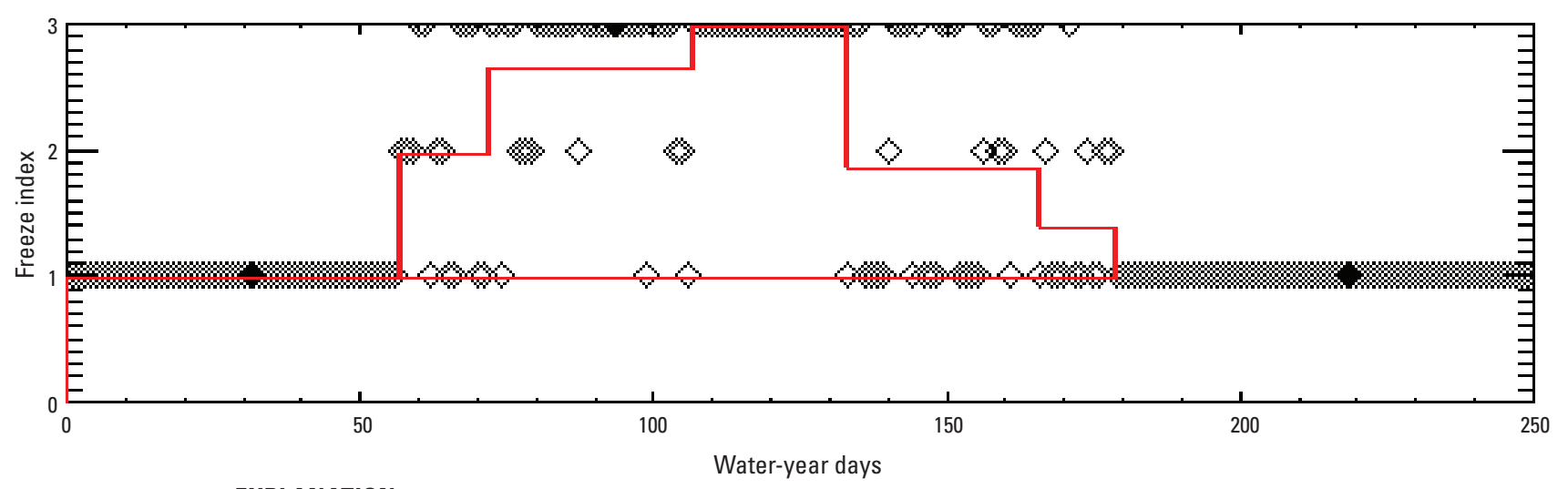

EXPLANATION

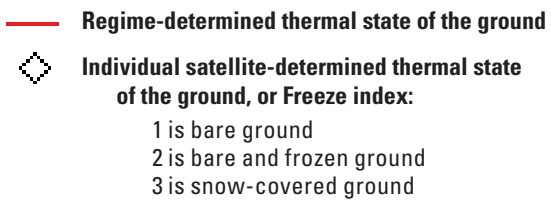

Figure 8. Example time series of the progression from bare ground to frozen ground and then to snow-covered ground at an AgriMet site at Picabo, Idaho, water year 1991. Regime shifts are shown at water year days 57, 72, and 179.

\section{Watershed Model}

The USGS Precipitation Runoff Modeling System (PRMS) watershed model (Leavesley, and others, 1983) was used for the small basin studies. The PRMS simulates runoff and recharge responses to inputs of daily precipitation and minimum and maximum air temperature and is typically operated at the daily time step as was done in this study. The PRMS is a physically based, distributed-parameter model that simulates the moisture balance of each component of the hydrologic cycle for discrete hydrologically-similar land units called Hydrologic Response Units (HRUs). This model was selected for this study because a model from a previous study exists for a basin in the Columbia Plateau, and has been modified with a Continuous Frozen Ground Index (CFGI) that estimates periods when the ground is frozen and simulates a corresponding runoff response. Mastin (2009) described how the CFGI is used with PRMS in more detail in an application on Crab Creek in the Columbia Plateau.

Simulations of runoff and recharge using the PRMS watershed model were made at two basins for this study, upper Crab Creek, Washington, and Reynolds Creek, Idaho. The upper Crab Creek Basin is in eastern Washington in a relatively low-relief, shrub-steppe grassland region of the Columbia Plateau (fig. 9). The calibrated model existed prior to this study and was used to run long-term simulations into the future under several emission scenarios using downscaled input from several global circulation models (GCMs) to illustrate possible changes to the frequency of frozen ground and how it may affect recharge. The Reynolds Creek
Experimental Basin is in Idaho at the eastern edge of the Snake River Plain (fig. 10). The difference in elevations in the Reynolds Creek Basin is larger than the differences in the Crab Creek Basin and illustrates the mesoscale spatial effects of frozen ground and recharge in a small basin $\left(92 \mathrm{mi}^{2}\right)$. The PRMS model for the Reynolds Creek Basin was constructed and calibrated for this study.

\section{Upper Crab Creek Simulations}

The existing USGS, PRMS watershed model was constructed for three modeling units of three separate basins that drain into Potholes Reservoir in central Washington State (Mastin, 2009). The frozen-ground algorithm that was added to the model uses a CFGI to estimate when ground is frozen. When a threshold value is exceeded by the index, all potential water that is available to infiltrate the soil is routed to a surface-water outflow, which eliminates all recharge. The CFGI has improved the success of the model in simulating frozen-ground peak discharges, but still undersimulates some peaks and oversimulates others. The Crab Creek modeling unit was used for this study, but the original model was reduced in spatial extent to include only the upper basin that extends approximately from the town of Davenport to Irby, Washington, where irrigation is less prominent than areas downstream of Irby (fig. 9, called hereafter the Upper Crab Creek model). This upper, headwater area of the basin includes several existing soil moisture and soil temperature stations that can be used for comparison with the simulated CFGI values. 


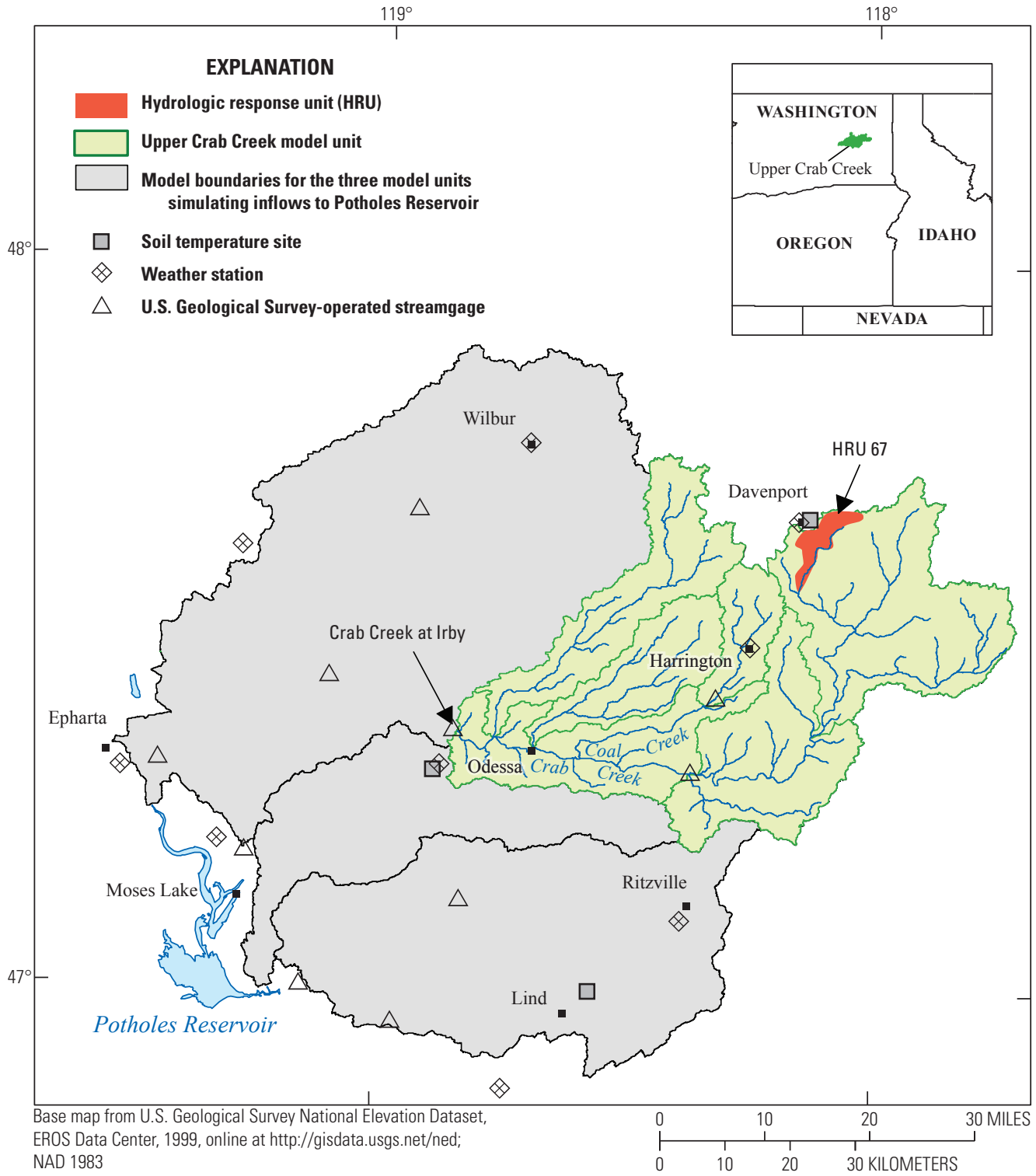

Figure 9. Existing watershed model boundaries for simulating inflows to Potholes Reservoir and the Upper Crab Creek Model used for this study, Washington. 


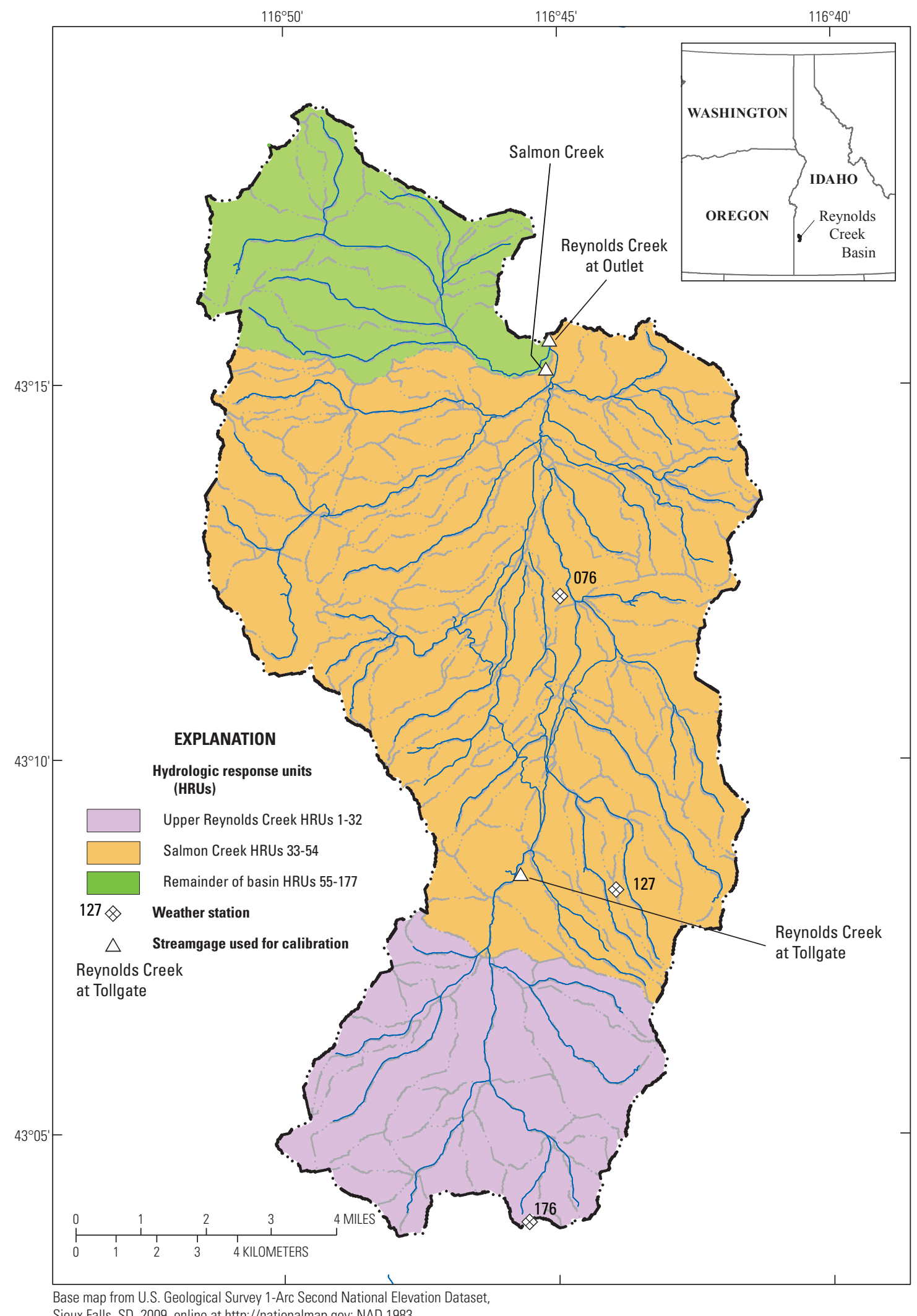

Figure 10. Watershed model boundaries and model sites in the Reynolds Creek Basin, Idaho. 
The CFGI was introduced by Molnau and Bissel (1983) to estimate the presence of frozen ground. CFGI increases only when the mean daily air temperature is less than $0^{\circ} \mathrm{C}$. Increasing snow-cover depth tends to reduce any increase in CFGI to a certain depth when no increase in CFGI is possible. A user-defined decay function reduces the index and another user-defined threshold value is used by the model to determine when to shut off simulated infiltration of water at ground surface (Larson and others, 2002; Mastin, 2009).

The Geographic Information System (GIS) Weasel tool (Viger, 2008) was used to partition the Upper Crab Creek model into HRU land units that are assumed to have a relatively homogenous runoff and recharge response to the climatological inputs of daily precipitation and daily minimum and maximum air temperature. The original Crab Creek Modeling Unit has 387 HRUs incorporating the Crab Creek Basin from the mouth of Crab Creek where it enters Moses Lake, including Rocky Ford Creek; the Upper Crab Creek model has 168 HRUs, which incorporate the Crab Creek basin upstream of the USGS-operated streamflow-gaging station Crab Creek at Irby (12465000). The PRMS watershed model simulates runoff and recharge for each HRU as well as the basin-wide variable of recharge. The Upper Crab Creek model represents a $1,036 \mathrm{mi}^{2}$ area upstream of where the Columbia Basin Project (CBP), managed by Reclamation, imports large amounts of surface water from the Columbia River for irrigation. The imported irrigation water has a pronounced effect on the shape of the runoff hydrograph during the growing season and overwhelms the volume of water produced by natural runoff. Dryland farming is common in the upper basin, but groundwater pumping and irrigation does occur in the basin simulated by the Upper Crab Creek model; however, the surface-water effects are less pronounced than within the CBP. More details of the PRMS watershed model and its application to Crab Creek are provided by Mastin (2009).

The Upper Crab Creek model does not provide a basinwide average value of CFGI, so this investigation simply looked at the CFGI for HRU 67 as a representative land unit near Davenport, Wash. that is near a USGS-operated soil temperature site (fig. 9). The CFGI threshold value was originally calibrated to improve peak-flow simulations of the model, and a threshold value of 137 was used. Molnau and Bissell (1983) suggested a transition range of CFGI values from 56 to 83, below which enhanced runoff because of frozen soils is unlikely, and above which enhanced runoff is highly likely.

For this investigation, a comparison of observed days of frozen ground to the simulated CFGI value at HRU 67 (fig. 9) was made to determine a reasonable CFGI value that could serve as an indicator of frozen ground for a baseline period of simulated recharge and for future forecasts of simulated recharge under various climate-change scenarios. The number of days in a water year that the CFGI value was exceeded was graphically compared with the number of days in a water year that minimum daily soil temperature was below freezing. Several values from 20 to 100 were tested, and the number of days with a CFGI value of 50 seemed to compare best with the number of days of observed freezing ground at the $2 \mathrm{in}$. depth (fig. 11). The soil dynamics of freezing and transmitting infiltrated water are complicated. These dynamics vary with depth and soil moisture content, and can vary spatially throughout the basin. The CFGI is simply an index, and it may not closely define the actual number of days that the soil is frozen enough to inhibit recharge. The intent for of this study was to use the threshold CFGI value of 50 as a relative measure of frozen ground to compare how it varies over time with various scenarios of climate change.

\section{Recharge for Possible Future Climate Scenarios-Upper Crab Creek}

To investigate how the duration of frozen soils may change in the future, assuming several climate emission scenarios (table 2), the air temperature and precipitation results of several GCMs were downscaled to the station locations used in the Upper Crab Creek model input of daily precipitation and daily minimum and maximum air temperatures. Simulations by the Upper Crab Creek model were made from the set of inputs from the GCMs and were averaged in the summary of the results. The emission scenarios describe how different patterns in greenhouse gas emissions could evolve between 2000 and 2099, from relatively high concentrations (SRESa2 in table 2 or just "a2") to medium (a1b), to low concentrations (b1). GCM outputs were obtained from the World Climate Research Programme's Coupled Model Intercomparison Project phase 3 multimodel dataset archive (Intergovernmental Panel on Climate Change, 2007). The methodology of downscaling the GCMs for the various climate-emission scenarios and processing the simulated results followed the methodology used by Markstrom and others (2012) in a national study examining runoff response to climate change. The same GCMs used by Markstrom and others (2012) were used in this investigation (table 3) and were selected because they had output suitable for the PRMS models and they contained monthly projections of precipitation and maximum and minimum temperature for the three scenarios. 


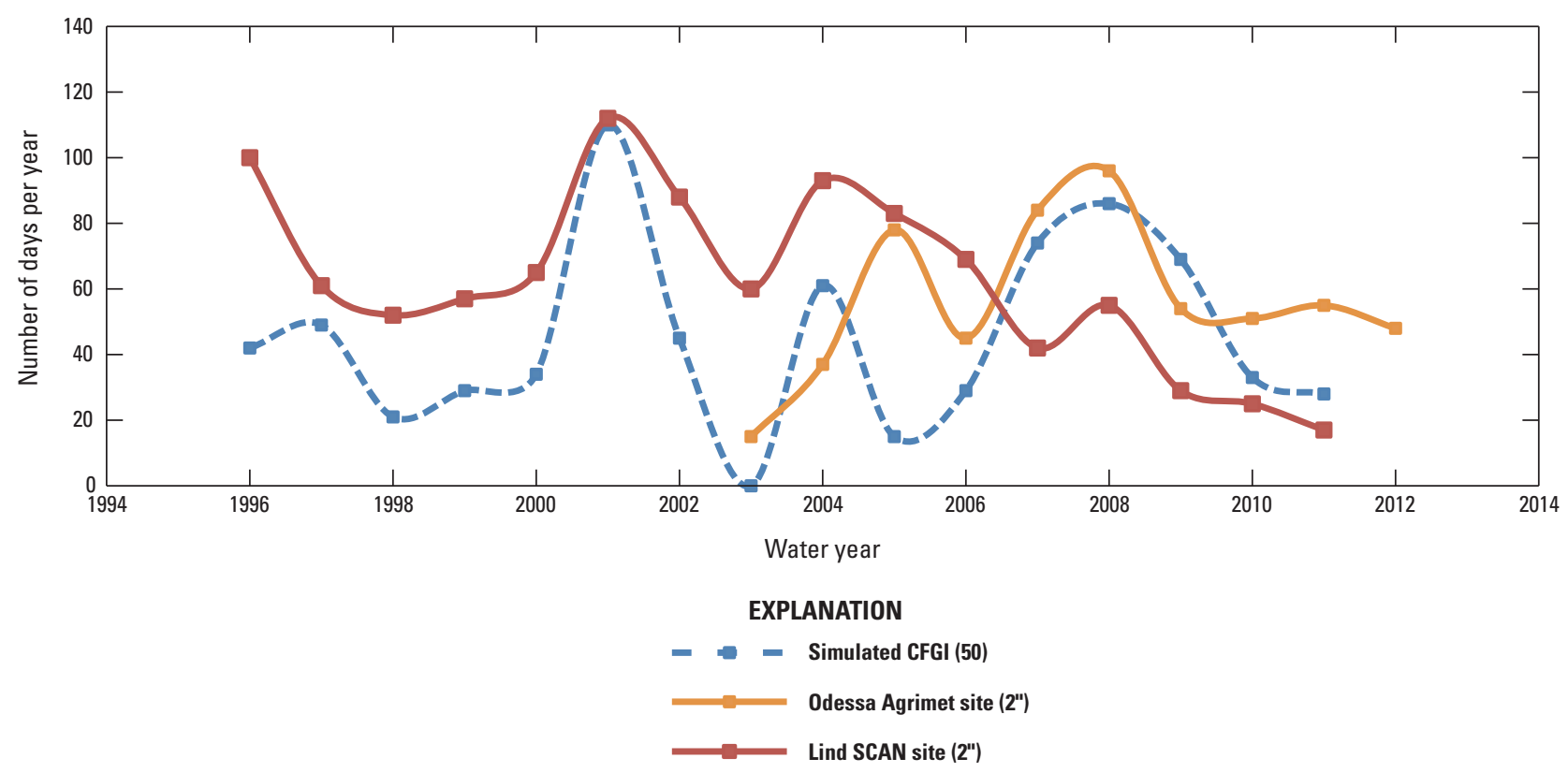

Figure 11. Number of days that simulated Continouous Frozen Ground Index (CFGI) for Hydrologic Response Unit 67 exceeded a value of 50 with the number of days that the minimum observed soil temperature was below freezing at a depth of 2 inches at the Soil Climate Analysis Network (SCAN) site, Lind, Washington site and the AgriMet site, Odessa, Washington, water years 1996-2012. Site locations are shown in figure 9.

Table 2. Simulated future climate scenarios (2001-99) in the Columbia Plateau and Snake River Plain study areas, Idaho, Oregon, and Washington.

[GCM scenario: Global circulation model scenario. Descriptions from Ruosteenoja and others, 2003]

\begin{tabular}{ll}
\hline $\begin{array}{c}\text { Climate emission } \\
\text { scenario }\end{array}$ & Description \\
\hline SRESa2 & Very heterogeneous world with high population growth and slow economic growth \\
SRESb1 & Convergent global low population growth and rapid changes in economic structure \\
SRESa1b & $\begin{array}{l}\text { Very rapid economic growth, a global population that peaks in mid-century, and rapid } \\
\text { introduction of new and efficient technologies balanced across all sources }\end{array}$ \\
\hline
\end{tabular}

Table 3. Global circulation models used in the Columbia Plateau and Snake River Plain study areas, Idaho, Oregon, and Washington.

[Data from Intergovernmental Panel on Climate Change, 2007]

\begin{tabular}{ll}
\hline $\begin{array}{c}\text { Global Circulation } \\
\text { Model }\end{array}$ & \multicolumn{1}{c}{ Center and country of origin } \\
\hline BCC-BCM2.0 & Bjerknes Centre for Climate Research, Norway \\
CSIRO-Mk3.0 & Commonwealth Scientific and Industrial Research Organization, Australia \\
CSIRO-Mk3.5 & Commonwealth Scientific and Industrial Research Organization, Australia \\
INM-CM3.0 & Institute for Numerical Mathematics, Russia \\
MIROC3.2 (medres) & National Institute for Environmental Studies, Japan \\
\hline
\end{tabular}


A base period was to represent mean current hydrological conditions in the basin. Future climate scenarios were simulated by estimating climate change factors for the scenario used and then using those factors to adjust the climate inputs of the base period. The period was limited to part of the current record to minimize the computational requirements, but long enough to include some annual variation that is common in the basin. The base period selected for this study was WYs 1984-2000. The input data for this period spans from WY 1983 to WY 2000, with the first year being a "warm-up" year of simulation to allow the boundary conditions of the model to converge on the actual values before simulation results are compiled. The model simulation results of this first warm-up year were not used in the analysis. Runoff has been below the mean at the mouth of the study area since WY 2000 (fig. 12), so a recent period of above and below mean runoff prior to WY 2001was selected.

Climate-change fields (percentage of changes in precipitation and degree Fahrenheit changes in temperature) were derived by calculating the mean monthly change in climate from the base period to future conditions simulated by each GCM for each emissions scenario. Output from the GCM is provided at specific grid locations, but the input time series of daily minimum and maximum air temperature and daily precipitation to the PRMS model was developed from data from local meteorological stations. The input temperatures and precipitation were subsequently distributed by the model to each of the HRUs. PRMS input time series for a specific meteorological station in the model for future scenarios were generated by applying the climate-change fields for the nearest GCM grid node to the baseline time series.

Future scenarios for a particular year are simulated by simulating a period record that is the same length (17 years) as the base period and centered over that particular year. The results are averaged over the simulation period and assigned to the selected year. The same 17-year length is used for each year into the future, creating a 17 -year moving window of simulation. By averaging the results, a continuous timeline of climate can be simulated. This resulted in the generation of 1,320 input time series and 1,320 model runs ( 88 years $\times 5 \mathrm{GCMs} \times 3$ emission scenarios). The automation of running the model and the organization of the output data was accomplished with a database following the procedure used by Voss and Mastin (2012).

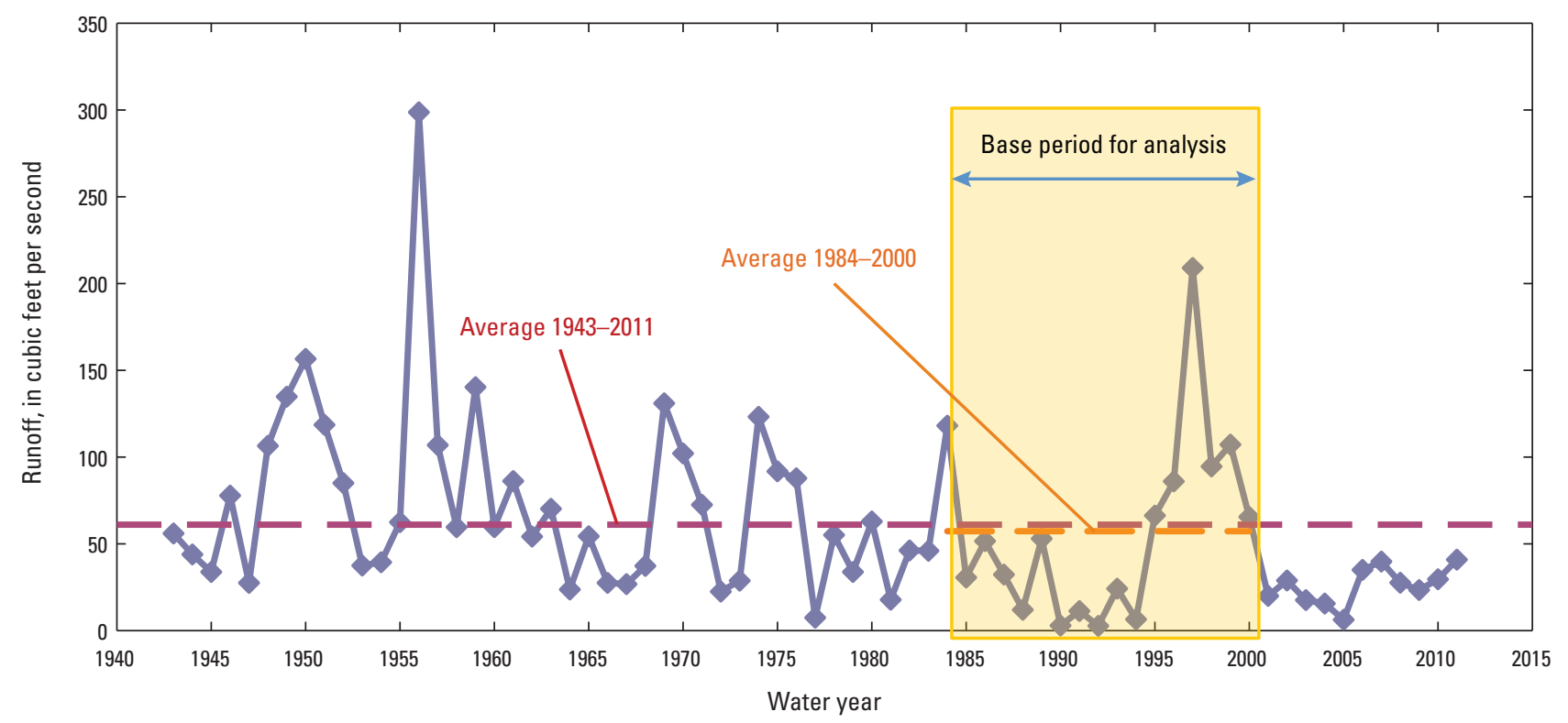

Figure 12. Annual mean runoff at Crab Creek at Irby, Washington (U.S. Geological Survey station 12465000). 


\section{Reynolds Creek Simulations}

A PRMS model was created and calibrated for the Reynolds Creek Basin. The GIS Weasel tool (Viger, 2008) was used to partition the basin into 177 HRUs (ig. 10) with an average size of 332 acres and to estimate most of the parameters for the model. Three meteorological sites operated by the USDA, Agricultural Research Service (Hanson and others, 2001) were used to generate the driving inputs to the model, which consist of daily precipitation and daily minimum and maximum air temperatures. These long-term weather sites are at low, medium, and high elevations (figs. 10 and 13): site $076 \times 59$ is at an elevation of $3,960 \mathrm{ft}$, site $127 \times 07$ is at an elevation of $5,420 \mathrm{ft}$, and site $176 \times 14$ is at an elevation of $6,880 \mathrm{ft}$. A data input file was generated for a common period of complete water years from the available data at all three sites for water years 1988-2008 (data were retrieved from a USDA website, see Hanson and others, 2001). A distribution of monthly and annual precipitation, needed to estimate several precipitation distribution model parameters, was developed for calendar years 1968 through 1990 using 16 precipitation sites in the basin and a GIS. Specifically, inverse distance weighting was used to distribute the observed monthly and annual site values throughout the basin.

Three streamgages in the basin operated by the USDA Agricultural Research Service were used to calibrate the model: (1) the Tollgate streamgage on the upper basin at an elevation of 4,587 ft, which drains an area of 13,511 acres, (2) the Salmon Creek streamgage at an elevation of 3,685 ft, which drains an area of 8,930 acres in the northwestern part of the Reynolds Creek Basin, and (3) the Outlet streamgage at the basin outlet at an elevation of 3,606 ft, which drains an area of 58,860 acres (figs. 10 and 13). Pierson and others (2001) described the long-term stream discharge data available for Reynolds Creek Basin, but a common period of WY 1985-96 was available for these three streamgages to calibrate the model. Four flow-routing segments were added to the PRMS model; three of the segments ended at the streamgage locations to allow comparison of simulated runoff with the measured runoff. The fourth segment simulated channel losses in the lower part of the main channel. The channel losses were added to the model to account for the discrepancy in the observed runoff. The sum of the mean annual observed discharge at Salmon Creek and Tollgate, whose basins contribute directly to Reynolds Creek, are 5 percent more than the discharge at the Outlet, despite the fact that the Outlet streamgage drainage area is more than 2.6 times larger than the combined drainage area of the Salmon Creek and Tollgate streamgages. It was assumed that the discrepancy in flows at the Outlet streamgage is because of channel losses; however, some of the losses may be due to irrigation diversions that occur along the creek at low elevations (Slaughter and others, 2001).

Calibration of the PRMS model parameters began with an adjustment of the jh_coef parameter, which is a coefficient in the Jensen-Haise algorithm to compute potential evapotranspiration (PET). The parameter was adjusted until the simulated PET of representative HRUs at the weather sites agreed within 11 percent observed annual PET data from evaporation pans.

The next step in the calibration process was adjusting the parameters so that the simulated monthly and annual runoff agreed approximately with observed runoff. Final calibration was achieved mainly with the adjustment of the input air temperatures and precipitation values, and by adding simulated channel losses (parameters channel_sink_pct and channel_ sink_thrshld). Air temperatures were adjusted by decreasing all HRU-distributed air temperatures by $4{ }^{\circ} \mathrm{F}$ (tmin_mo_adj and tmax_mo_adj parameters) to delay the simulated snowmelt runoff that otherwise was occurring too early in the season when compared to the observed runoff hydrograph. HRU-distributed precipitation values were decreased (rain mon and snow_mon parameters) by 27 percent for the upper basin (HRUs 1-32) and by 50 percent for the remainder of the basin. Even with these large adjustments, the simulated flow at the Outlet streamgage was much greater than the observed flow. At this point in the calibration process, the fourth flow-routing segment was added to represent the short reach on Reynolds Creek from the confluence with Salmon Creek to the Outlet streamgage. Channel losses are likely to occur in the other reaches in the basin, but they are simulated only in this lower reach for simplicity and because the spatial distribution of channel losses is not known. Channel losses were simulated by decreasing the inflow to the reach by 50 percent (channel_sink_pct parameter) to a threshold value of $50 \mathrm{ft}^{3} / \mathrm{s}$ (channel_sink_thrshld parameter) that restricts channel losses to $25 \mathrm{ft}^{3} / \mathrm{s}$ when flows are greater than $50 \mathrm{ft}^{3} / \mathrm{s}$.

Simulated mean annual runoff for WY 1985-96 was 3.4 percent greater than the observed annual runoff at Reynolds Creek at Tollgate (segment_cfs 1 in the model), 3.45 percent greater than the observed annual runoff at Salmon Creek (segment_cfs 2), and 0.14 percent less than the observed annual runoff at Reynolds Creek at Outlet (segment_cfs 4). Simulated mean monthly runoff for this same period reasonably mimicked the seasonal distribution of observed runoff (igg. 14). 


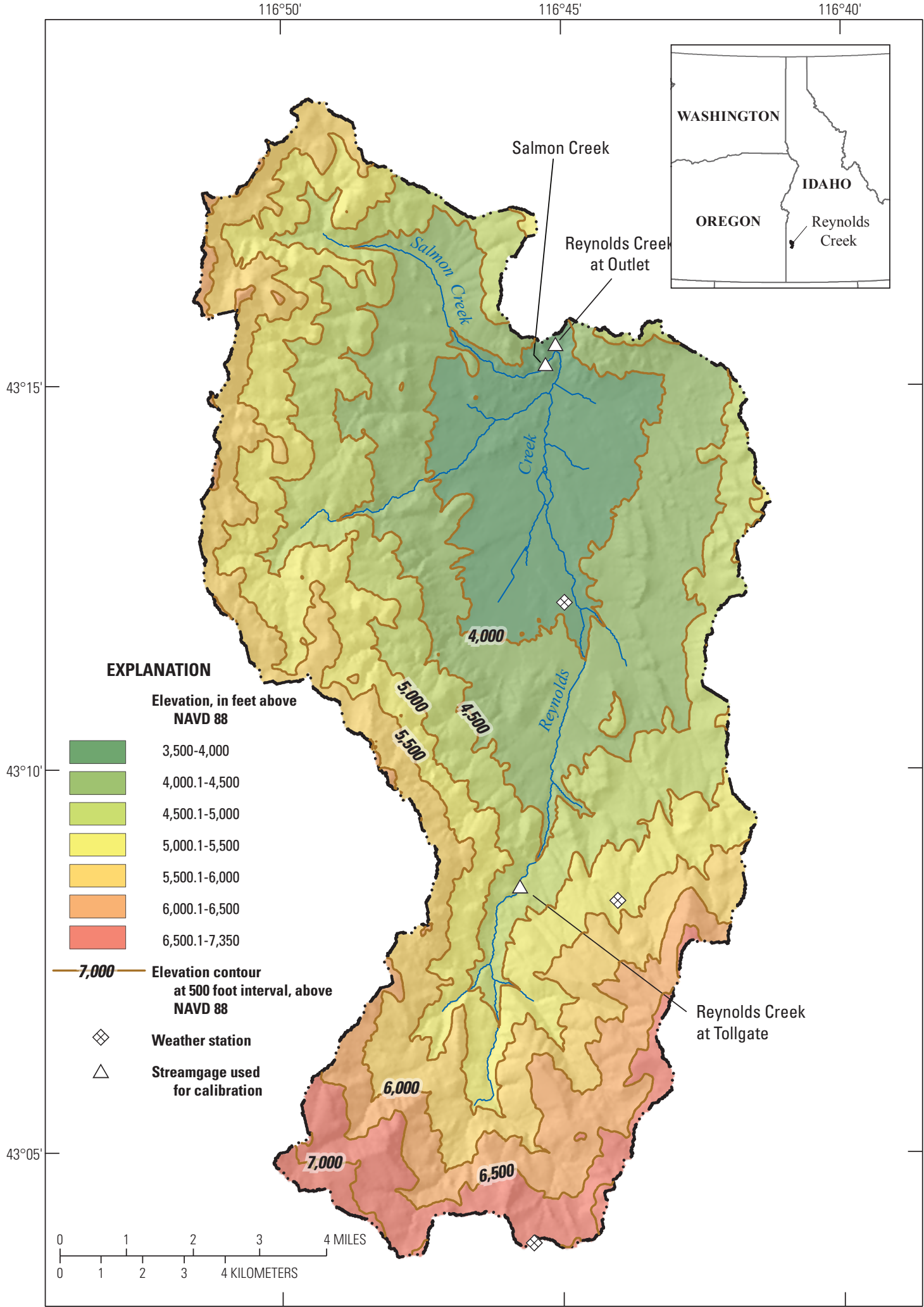

Base map from U.S. Geological Survey 1-Arc Second National Elevation Dataset, Sioux Falls, SD, 2009, online at http://nationalmap.gov; horizontal datum: North American datum of 1983

Figure 13. Elevation contours and locations of weather and streamflow-gaging stations used for input and calibration of the watershed model of Reynolds Creek, Idaho. 

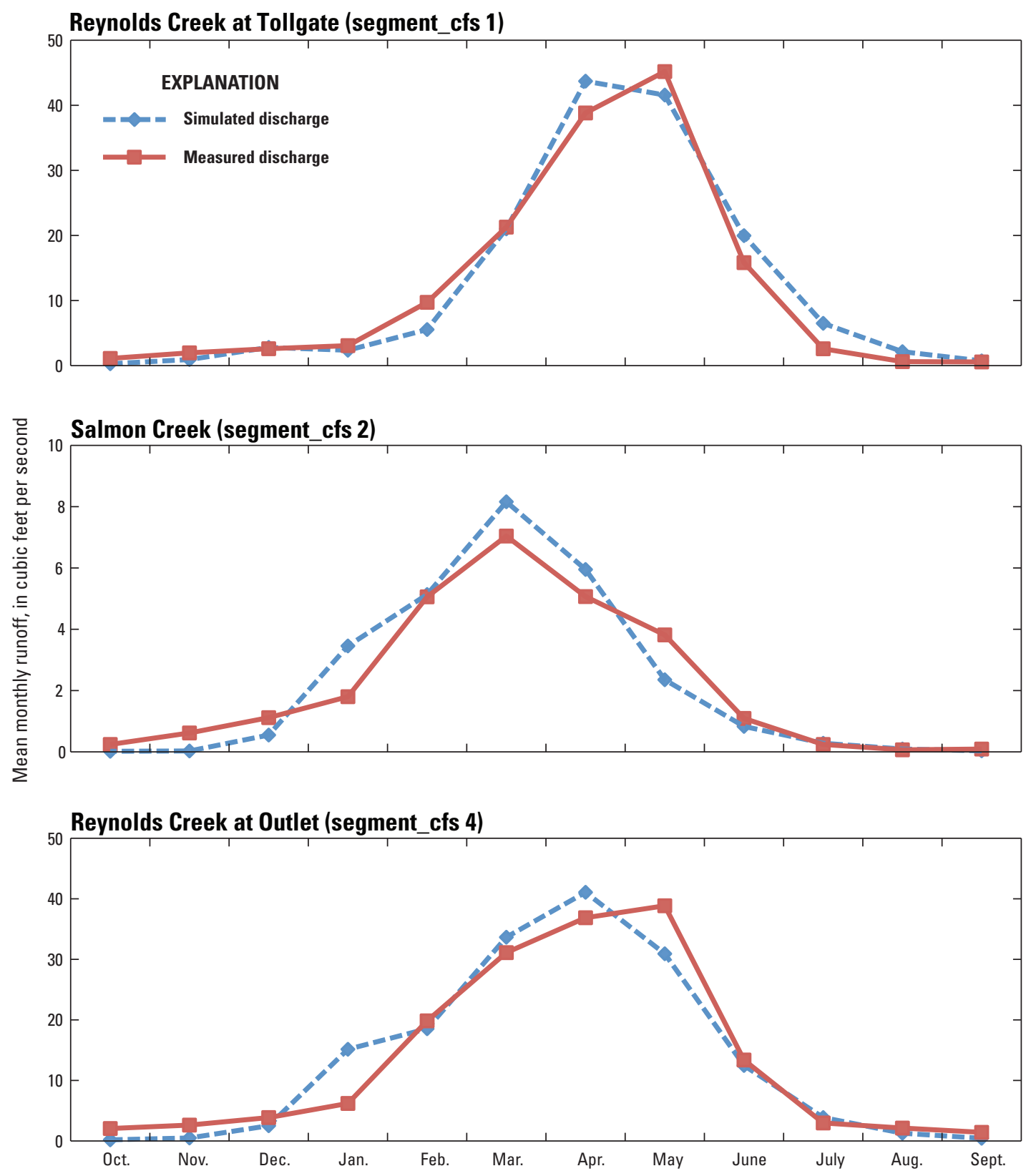

Figure 14. Simulated and measured mean monthly runoff at three calibration sites in the Reynolds Creek Basin, Idaho, water years 1985-96. 


\section{Recharge for Possible Future Climate Scenarios- Reynolds Creek}

Possible future climate scenarios were simulated in a different, simpler fashion than the Upper Crab Creek model simulations. The intent of the Reynolds Creek future climate scenarios was to show how recharge and frozen ground can vary spatially in a basin with some relief in the context of future climate scenarios. To do this, the minimum and maximum air temperature inputs were changed by monthly factors to represent the expected change in 2040 and 2080. Precipitation was not changed. Although a gradual increase in air temperatures is estimated by all the GCMs with a relatively small variation, Littell and others (2011, p. 27) note that "the range of precipitation projections is quite large among models." Mote and Salathé (2010, p. 41) wrote that from a weighted average of GCM ensembles, the annual mean change in precipitation for the Pacific Northwest "is practically zero throughout the twenty-first century, though individual models produce changes of as much as $-10 \%$ or $+20 \%$ by the 2080 s." The idea that precipitation in future 21 st century climate may not vary much from the current climate is strengthened by the fact that Nayak and others (2010) did not find any trend in annual precipitation in the Reynolds Creek basin over the period 1962-2006; however, significant trends of increasing temperature were related to decreasing maximum seasonal snow-water equivalent at all elevations. Therefore, with limited evidence that precipitation amounts will change in the future, the analysis was simplified by assuming precipitation is the same as the baseline period of record for these simulations of possible future climate in the Reynolds Creek basin.

GCMs are consistent in their projections of a warmer future climate and are able to detect various rates of air temperature change by season. Littell and others (2011) took a subset of GCMs (10 models) that performed best for the Pacific Northwest and computed the mean air temperature change for the SRESalb emission scenario for four seasons for 2040 and 2080. These temperature changes (table 4) were incorporated into two models that represent a possible future climate for 2040 and 2080 (hereafter referred to as the 2040 model and the 2080 model) and then changes in the output from a baseline model run simulation were analyzed. The baseline period selected for this analysis was WY 1989-99, a period when simulated runoff averaged $14.6 \mathrm{ft}^{3} / \mathrm{s}$, which was just $0.3 \mathrm{ft}^{3} / \mathrm{s}$ higher than the long-term average from water years 1984-2008. One year of warm-up in the model was simulated prior to the baseline period to allow the boundary conditions of the model to converge on the true values. The 2040 and 2080 models were constructed from the calibrated model with the temperature changes (table 4) subtracted from the tmin_mo_adj and tmax_mo_adj parameters. The model uses these parameters and subtracts them from the calculated daily minimum and maximum temperatures for each HRU. The daily range in temperature is used to estimate sky cover, which is then used to estimate incoming shortwave radiation at each HRU. However, this is performed by the model prior making adjustment to temperature with the tmin_mo_adj and tmax_mo_adj paramenters. The result is that the daily incoming shortwave radiation in this analysis is the same for the baseline, 2040, and 2080 model runs. The 2040 and 2080 model runs were done for the same 11-year period as the baseline period, and the results were averaged to represent the possible climate and hydrology of 2040 and 2080, respectively.

Table 4. Mean seasonal increases in air temperature from ensembles of $10 \mathrm{global}$ circulation models for the SRESa1b emission scenario used in simulations for Reynolds Creek Basin, Idaho.

[Simulations from Little and others, 2011. Abbreviations: ${ }^{\circ} \mathrm{C}$, degrees Celsius; ${ }^{\circ} \mathrm{F}$, degrees Fahrenheit]

\begin{tabular}{clll}
\hline \multirow{2}{*}{$\begin{array}{c}\text { Representative } \\
\text { year }\end{array}$} & \multicolumn{1}{c}{$\begin{array}{c}\text { Seasons } \\
\text { (as defined by months) }\end{array}$} & \multicolumn{2}{c}{ Temperature } \\
\cline { 3 - 4 } 2040 & ( $\left.{ }^{\circ} \mathbf{F}\right)$ & $\left({ }^{\circ} \mathbf{C}\right)$ \\
\hline \multirow{2}{*}{2080} & Mecember-February & 3.24 & 1.8 \\
& Jurch-May & 3.06 & 1.7 \\
& September-November & 3.96 & 2.7 \\
& December-February & 6.12 & 2.2 \\
& March-May & 5.76 & 3.2 \\
& June-August & 8.82 & 4.9 \\
& September-November & 7.02 & 3.9 \\
\hline
\end{tabular}

\section{Results from Monitoring Regional Recharge and Simulating Recharge in Representative Basins}

The results of applying an existing algorithm to the data from satellite remote sensing of the two large regions in the study area combined with a statistical regime analysis to identify the ground surface state show a promising methodology to estimate an annual count of days of frozen ground and days of snow cover. Following the second line of investigation for this project, the hydrologic simulation of two representative basins under future possible climates show how hydrologic processes interact to affect recharge in seasonally frozen ground. 


\section{Satellite Remote Sensing Results}

A limited comparison of the thermal state of the ground, as measured by in situ temperature observations and the satellite remote sensing data, was completed. Because the algorithm had been verified and published, no further comparisons were made. Instead, this investigation focused on application of the algorithm. The color-coded pixel maps that show the various results vary spatially within the study areas. Complete sets of the 21-year results presented as color-coded pixel maps of the processed satellite remote sensing data are presented in appendixes A, B, and C. Appendix A contains the complete set of color-coded map graphics showing the 21 years of the annual number of days of frozen soil and snow cover for each $15.5 \times 15.5 \mathrm{mi}$ pixel in the study area. Appendix B contains the complete set of color-coded map graphics showing 21 years of the water-year day when the ground first becomes frozen as determined by regime analysis and water-year day when the first snow cover begins using regime analysis. Appendix C contains the complete set of color-coded map graphics of the difference in days of the number of snow-covered ground minus the number of days of frozen ground and the complete set of color-coded map graphics of the water-year-end day of the snow season as defined with regime analysis.
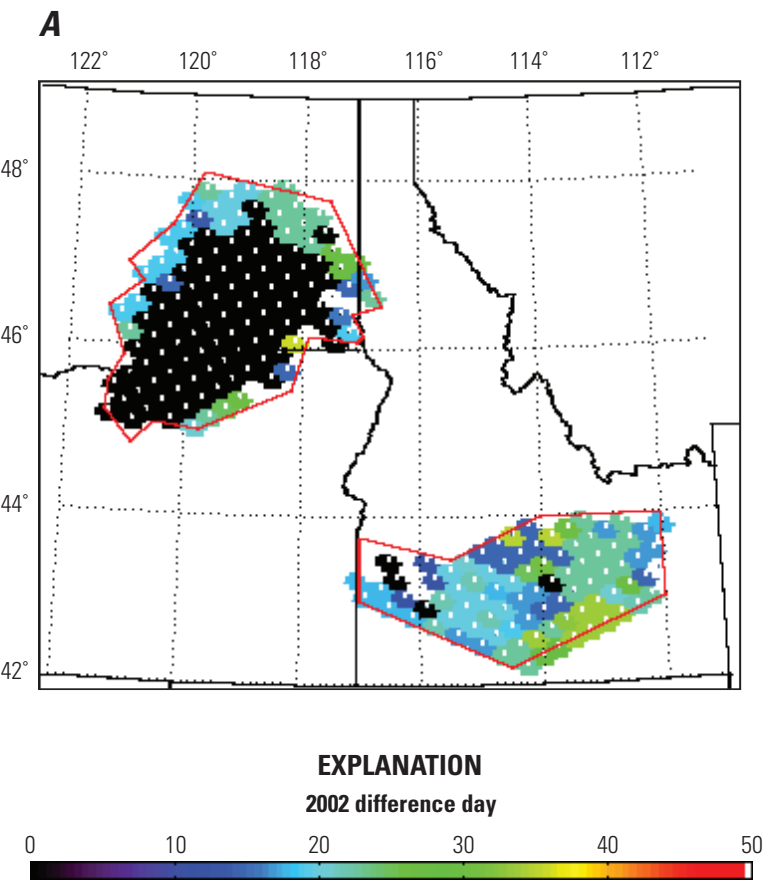

\section{Results from Regime Analysis}

Color-coded pixel maps in appendix B of the water-year day indicate when frozen ground was detected and when a pixel was classified as being snow covered ground using the regime analysis. Similarly, color-coded maps in appendix C indicate the number of days, if any, between the occurrence of frozen ground and snow cover. Maps of the end of the snow season are also provided in appendix $\mathrm{C}$. The difference maps show significantly different behavior between each region. For the Columbia Plateau, there is generally little difference except for the high elevation perimeter, which can exhibit considerable differences. For the Snake River Plain, the temporal lag varies from year to year and by location, as seen in the contrast between the 2002 map and the 2003 map (fig. 15).

The maps of the end of the snow cover (labeled as "Melt Day") in appendix C show that the length of snow cover is dependent on elevation, with the high elevation areas remaining snow covered for the longest period of time. The maps generally show that the Snake River Plain is more snow covered than the Columbia Plateau. To investigate annual fluctuations and search for trends, each map in appendix A was spatially averaged to get the annual average number of days that a pixel was either frozen or snow covered. The

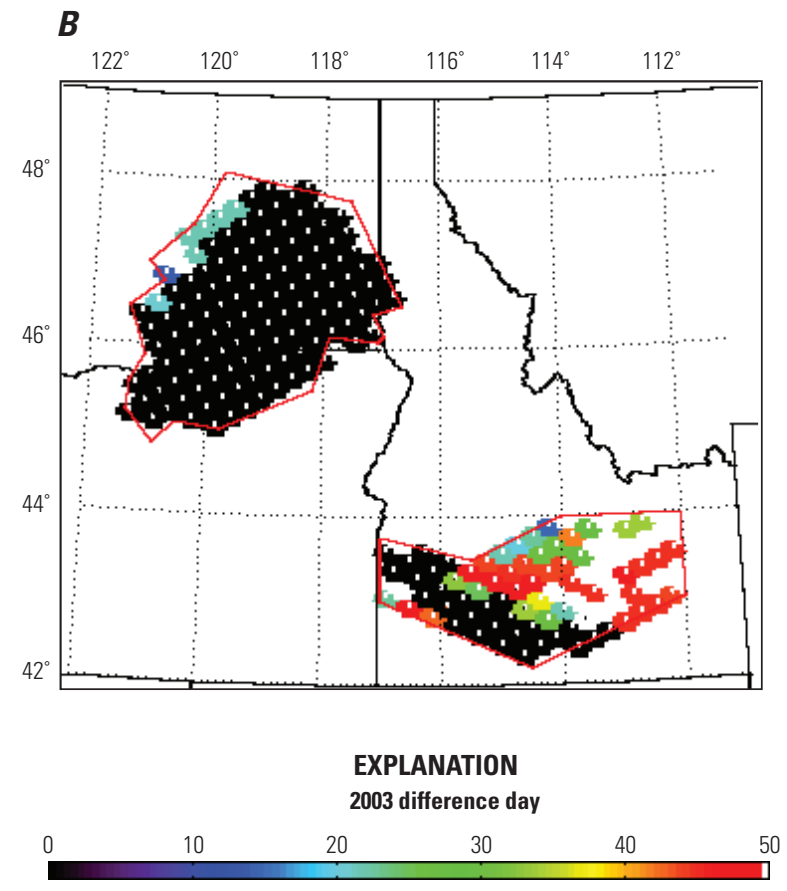

Figure 15. Difference in days of snow-covered days minus frozen-ground days in the Columbia Plateau and Snake River Plain study areas, Idaho, Oregon, and Washington, water years (A) 2002 and $(B) 2003$. 
number of days with frozen ground in the Columbia Plateau (fig. 16) ranges from approximately 20 to 40 , whereas the number of snow-covered days ranges from almost zero to 50. For the Snake River Plain (fig. 17), the number of days with frozen ground is comparable to the Columbia Plateau, but the occurrence of snow-covered area is much greater, ranging from about 60 to 100 days. Furthermore, there is an indication of a negative correlation between snow cover and frozen ground, an expected result as increased snow cover decreases the area that could exhibit frozen ground microwave signatures.

\section{Upper Crab Creek Simulation Results}

Figures $\underline{18}-\underline{22}$ are range plots that show the range in the 17-year moving mean of daily values by scenario for the Upper Crab Creek model. The three colored-dot lines, one for each emission scenario, indicate the daily average of the five GCM projections for the indicated year centered on the 17-year moving window of the model runs. The shaded areas shown for each scenario indicate the range of the daily average for the five GCM projections simulated by the PRMS model for each emission scenario. The range plots provide a visual representation of the trend and variability of the data. For example, figure 18 shows the annual basin mean daily maximum temperature with a relatively steadily-increasing trend for all three emission scenarios, and relatively low variability between the different GCMs - all the models seem to be in agreement that temperature will gradually increase into the future. Figure 19 shows the annual basin mean daily precipitation and much more variability in the range of GCM results indicating less agreement between the different GCMs. Although there is a general trend of increasing precipitation into the future, the trend of the low emission scenario, sresb1, is less discernible and has a decreasing trend beginning 2080 .
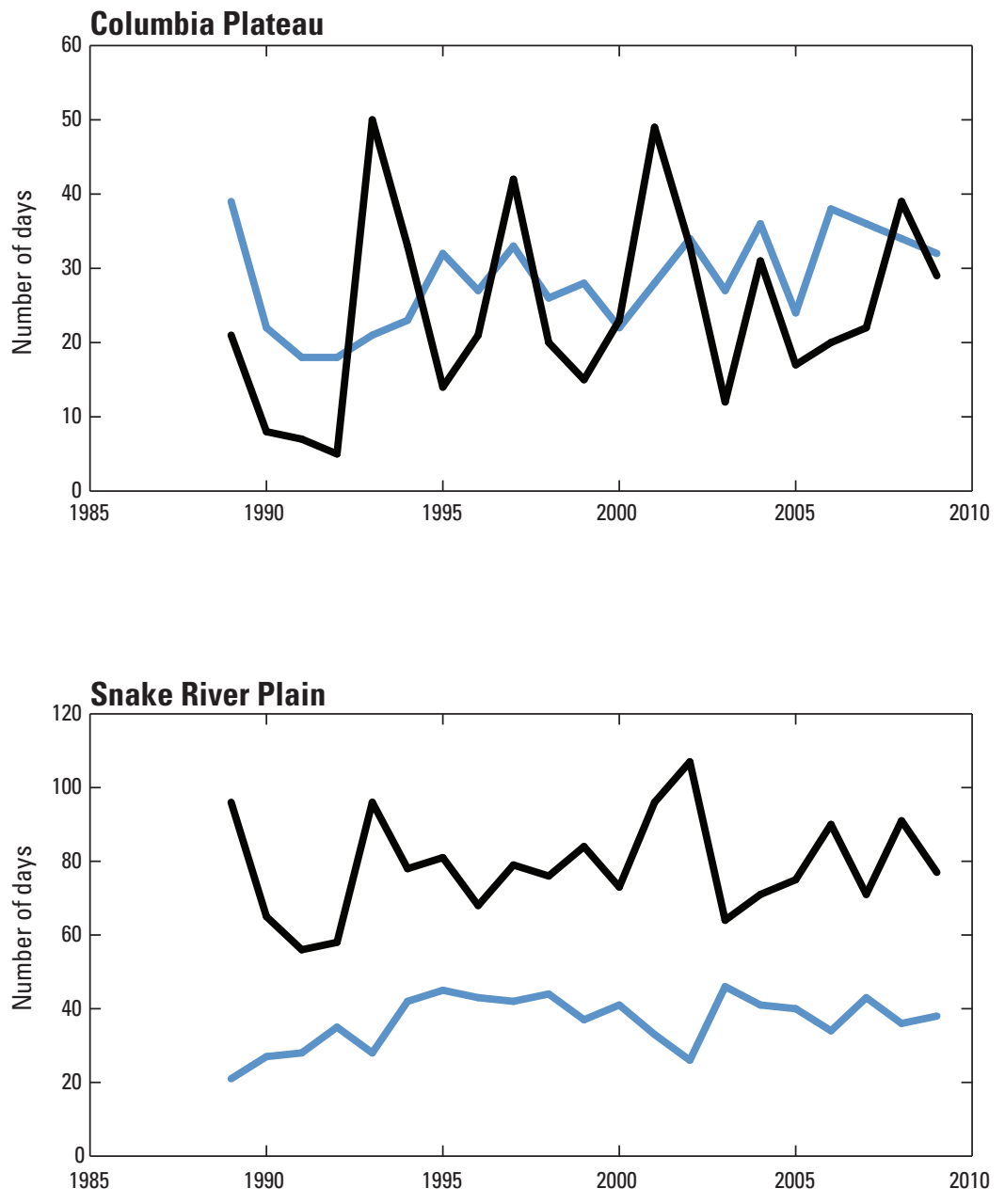

EXPLANATION

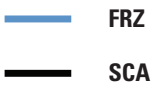

Figure 16. Annual average number of days by pixel estimated from processed satellite remote sensing data to be either frozen (FRZ) or snow covered (SCA), Columbia Plateau, Idaho, Oregon, and Washington.

EXPLANATION

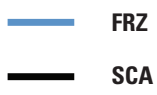

Figure 17. Annual average number of days by pixel estimated from processed satellite remote sensing data to be either frozen (FRZ) or snow covered (SCA), Snake River Plain, Idaho and Oregon. 


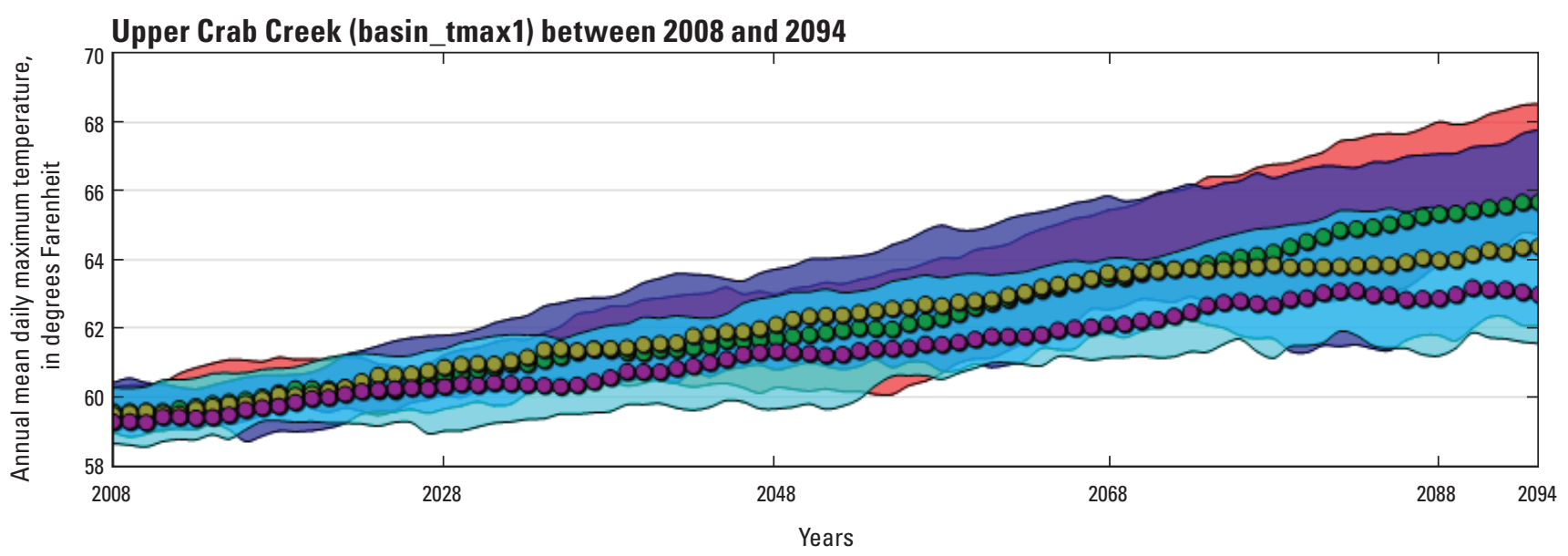

EXPLANATION

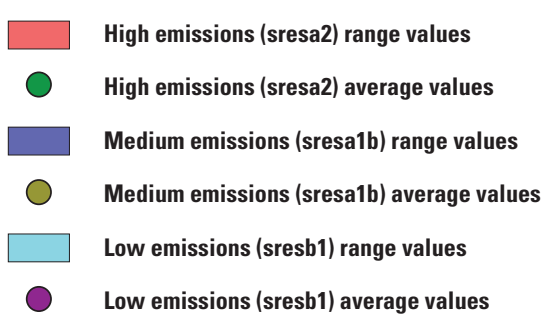

Figure 18. Simulated basin-averaged, annual mean daily maximum temperature for the upper Crab Creek, Columbia Plateau, Washington, water years 2008-94. When two or more range symbols overlap, an undefined combination of the colors indicates different temperature ranges.

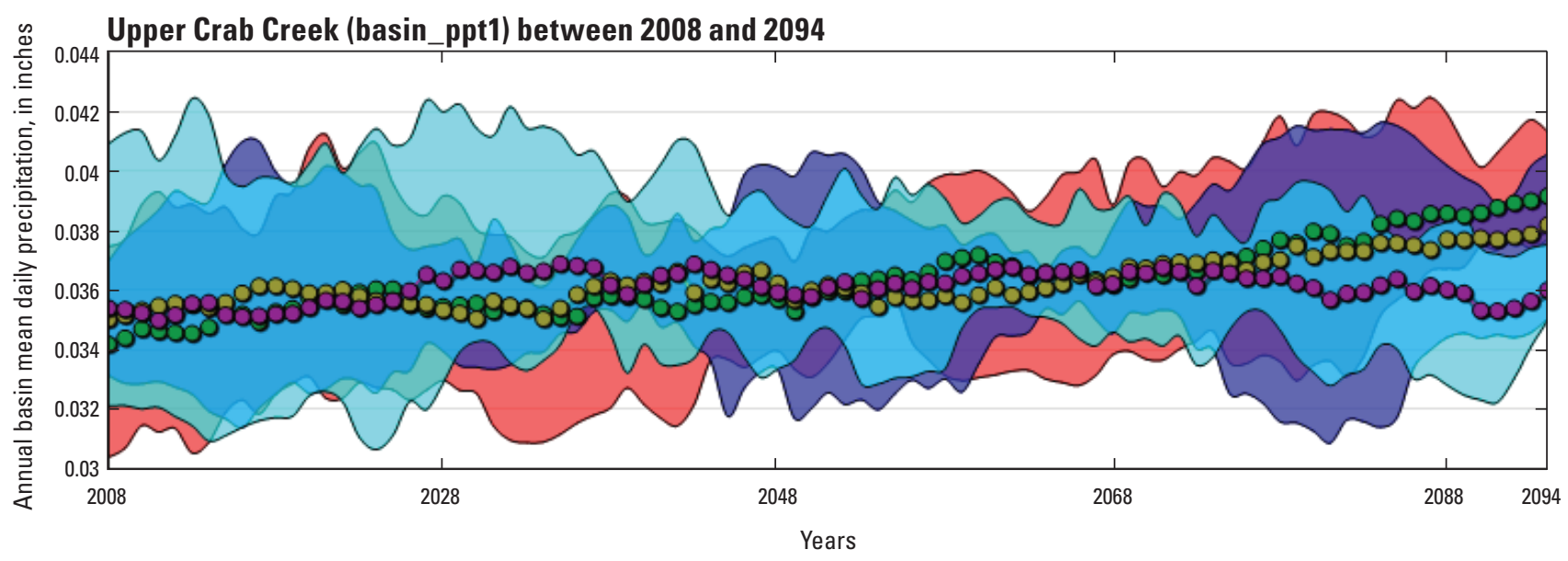

\section{EXPLANATION}

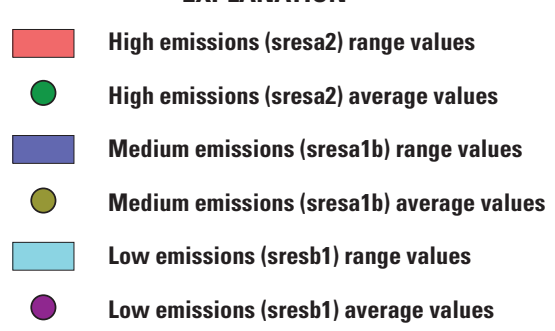

Figure 19. Simulated basin-averaged, annual mean daily precipitation for the upper Crab Creek, Columbia Plateau, Washington, water years 2008-94. When two or more range symbols overlap, an undefined combination of the colors indicates different precipitation ranges. 


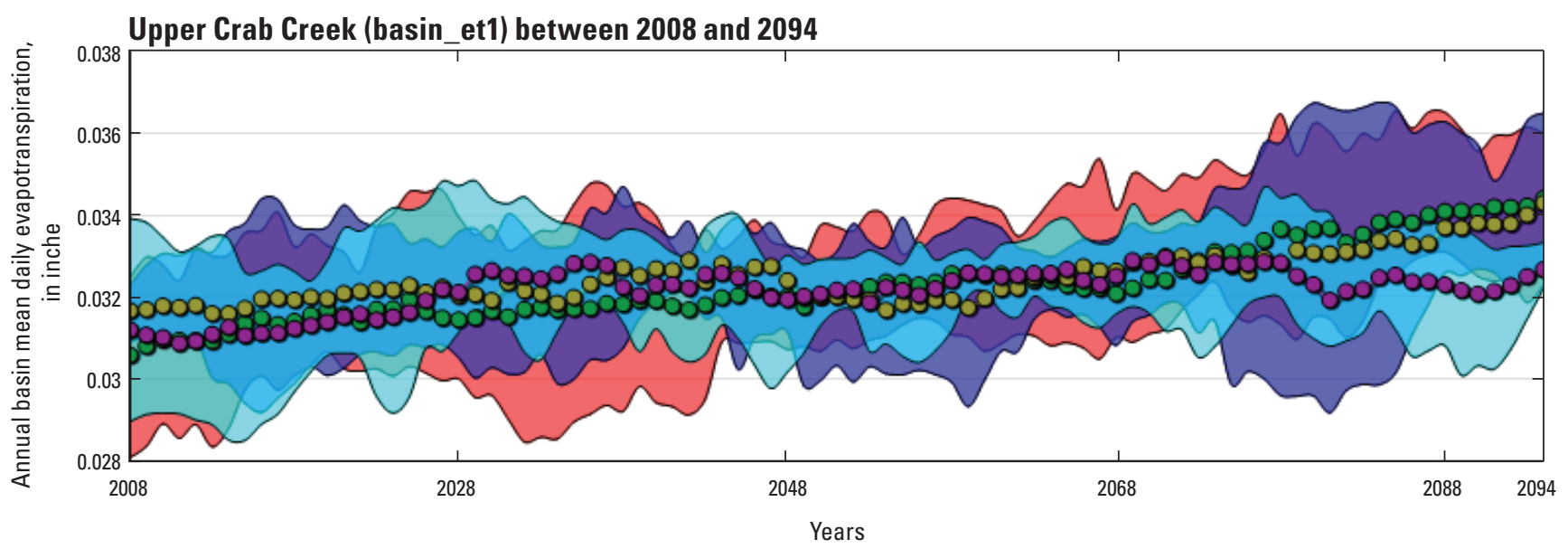

EXPLANATION

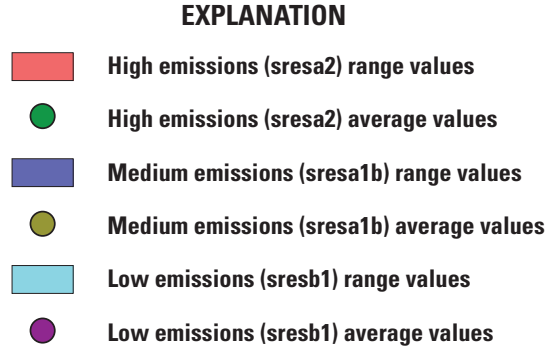

Figure 20. Simulated basin-averaged, annual mean daily evapotranspiration for the upper Crab Creek, Columbia Plateau, Washington, water years 2008-94. When two or more range symbols overlap, an undefined combination of the colors indicates different evapotranspiration ranges.

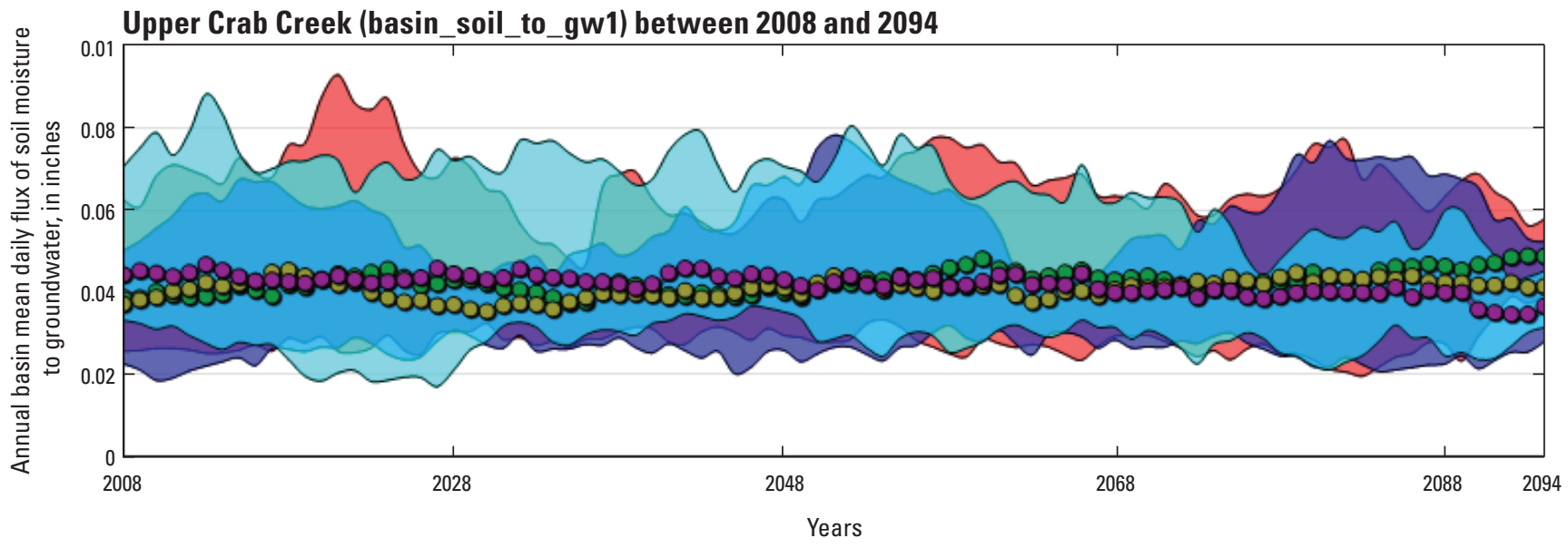

\section{EXPLANATION}

High emissions (sresa2) range values

High emissions (sresa2) average values

Medium emissions (sresa1b) range values

Medium emissions (sresa1b) average values

Low emissions (sresb1) range values

Low emissions (sresb1) average values

Figure 21. Simulated basin-averaged, annual mean daily moisture movement from soil to groundwater and representative of recharge in the basin for the upper Crab Creek, Columbia Plateau, Washington, water years 2008-94. When two or more range symbols overlap, an undefined combination of the colors indicates different flux ranges. 


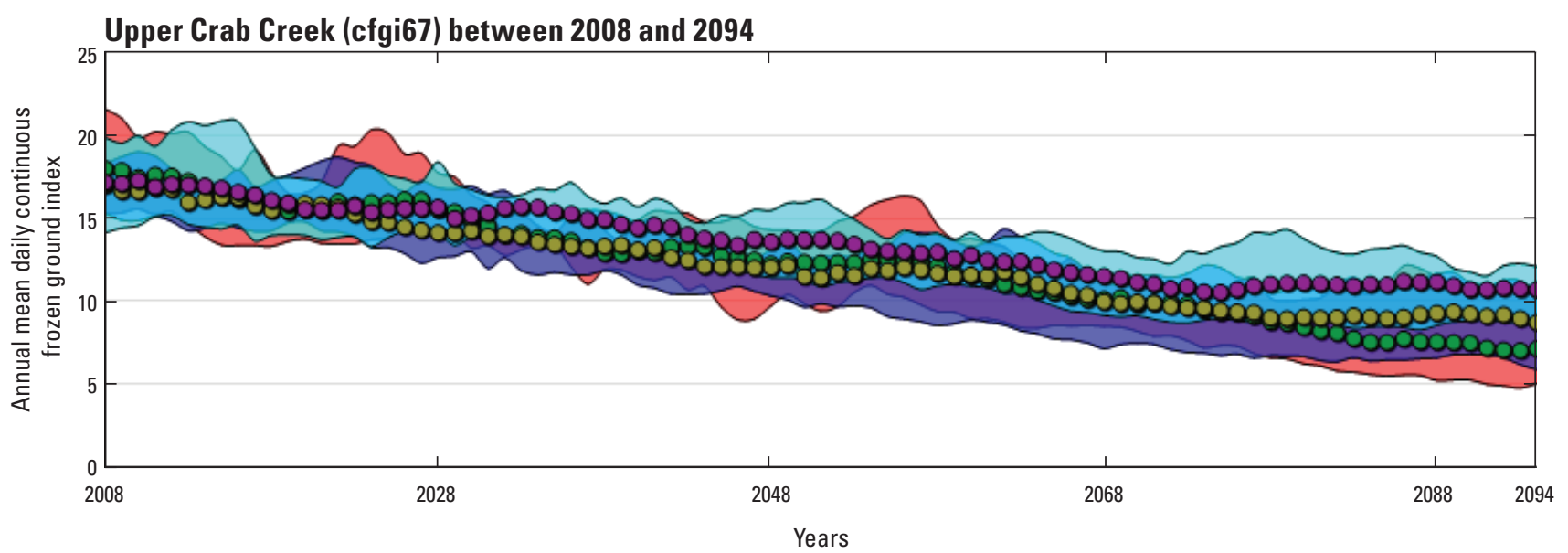

EXPLANATION

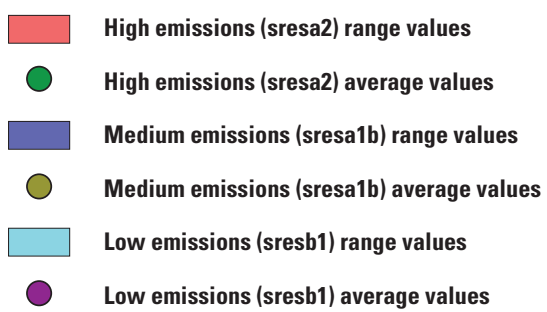

Figure 22. Annual mean daily continuous frozen ground index (CFGI) for hydrologic response unit 67 for the upper Crab Creek, Columbia Plateau, Washington, water years 2008-94. When two or more range symbols overlap, an undefined combination of the colors indicates different index ranges.

The range plots show increasing simulated temperature into the future in the Columbia Plateau (fig. 18), resulting in increasing evapotranspiration (fig. 20). Precipitation shows a positive trend into the future (fig. 19) that will tend to counteract the loss of moisture because of increasing evapotranspiration. Simulated basin-average recharge is the addition of two simulated variables basin_soil_to_gw or the flux of moisture moving from the soil to groundwater and basin_ssr2gw or the flux of moisture moving from the simulated subsurface water reservoir to gound water. Basin_ssr2gw in the Upper Crab Creek model is less than 0.5 percent of the annual daily averages of basin_soil_to_gw; therefore, the basin_soil_to_gw is representative of the recharge to groundwater and shows a weak increasing tread for emission scenarios SRESab1 and SRESa2, but a weak decreasing trend for emission scenario SRESb1 (fig. 21). This lack of a strong trend in either direction is likely because of the effect of increased evapotranspiration decreasing the amount of moisture available for recharge into the future and increased precipitation offsetting one another. The simulated difference in basin precipitation between the 2008 and 2094 values are similar in magnitude of the difference in simulated evapotranspiration between the 2008 and 2094 values. The differences in daily precipitation for the three scenarios sresa2, sresa1b, and sresab1 are $0.0050,0.00318$, and 0.0006 in., respectively (fig. 19). The differences in daily evapotranspiration for the three scenarios sresa2, sresa1b, and sresab1 are $0.0038,0.0026$, and 0.0015 in., respectively. The decreasing trend in the CFGI (fig. 22) is represented with the variable CFGI67, which is the CFGI value for HRU 67, a land unit near Davenport, Wash. (fig. 9); there is no basin-wide average variable for CFGI. As air temperatures increase in the future, the original study hypothesis suggests that the occurance of frozen ground would decrease and recharge would increase. The CFGI is an indicator of frozen ground, but the decreasing trend of the CFGI value into the future does imply a decreasing occurance of frozen ground, as hypothesized.

The slope or change of the average values and the regression coefficient $\left(\mathrm{R}^{2}\right)$ for selected simulated variables are shown in table 5. The slope indicates the change in the variable by year and regression coefficient indicates the strength of the linear association of the variable with time. Some plots of the residuals (not shown in report) showed signs of serial correlation and several of the plots (such as figs. $\underline{18}$ and 20) did not consistantly exhibit a linear trend. Part of the reason for this pattern at these sites may be because of the timing of the emission scenarios such as the scenario of rapid economic and population growth that peaks in mid-twentith century followed by the introduction of efficient technology 
Table 5. Projected change by year by linear regression model and the median of the year-toyear difference on the central tendencies of five global circulation models for three emission scenarios for selected Precipitation Runoff Modeling System (PRMS) output variables, upper Crab Creek, Washington.

[The slope and intercept of the linear regression model are given with probabilities that the values are not zero along with the regression coefficient $\left(\mathrm{R}^{2}\right)$ PRMS output variable: From Precipitation Runoff Modeling System, basin_ppt is the basin-averaged, average daily precipitation; basin_tmax is the basin-averaged, average daily maximum air temperature in degrees Farenheit; basin_tmin is the basin-averaged, average daily minimum air temperature in degrees Farenheit; basin_potet is the basin-averaged, average daily potential evapotranspiration; basin_et is the basin-averaged, average daily actual evapotranspiration; basin_snow is the basin-averaged, average daily snow-water equivalent; recharge is the sum of two basin-averaged simulated moisture fluxes, one flux is from the simulated subsurface reservoir to the groundwater reservoir and the other is the simulated flux from the soil reservoir to the groundwater reservoir; CFGI_67 is the Continuous Frozen Ground Index for hydrologic response unit 67, a land unit in the model area near Davenport, Washington. $<$, less than; >, greater than]

\begin{tabular}{|c|c|c|c|c|c|c|}
\hline \multirow{2}{*}{$\begin{array}{c}\text { PRMS } \\
\text { output } \\
\text { variable }\end{array}$} & \multicolumn{6}{|c|}{ Scenario SRESab1 } \\
\hline & Intercept & p-value & Slope & p-value & $\mathbf{R}^{2}$ & $\begin{array}{c}\text { Year to year } \\
\text { difference median }\end{array}$ \\
\hline basin_ppt & -0.0180 & 0.000006 & 0.00003 & $<2 \mathrm{e}-16$ & 0.7136 & 0.00001 \\
\hline basin_tmax & -60.0600 & $<2 \mathrm{e}-16$ & 0.05959 & $<2 \mathrm{e}-16$ & 0.9809 & 0.05295 \\
\hline basin_tmin & -95.1902 & $<2 \mathrm{e}-16$ & 0.06506 & $<2 \mathrm{e}-16$ & 0.9911 & 0.06298 \\
\hline basin_potet & -0.2997 & $<2 \mathrm{e}-16$ & 0.00022 & $<2 \mathrm{e}-16$ & 0.9884 & 0.00020 \\
\hline basin_et & -0.0090 & 0.006240 & 0.00002 & $<2 \mathrm{e}-16$ & 0.6625 & 0.00003 \\
\hline basin_snow & 0.0851 & $<2 \mathrm{e}-16$ & -0.00004 & $<2 \mathrm{e}-16$ & 0.9645 & -0.00005 \\
\hline recharge & -0.0039 & 0.038400 & 0.00000 & 0.000048 & 0.1778 & 0.00002 \\
\hline CFGI_67 & 214.7055 & $<2 \mathrm{e}-16$ & -0.09874 & $<2 \mathrm{e}-16$ & 0.9668 & -0.09097 \\
\hline \multirow{2}{*}{$\begin{array}{c}\text { PRMS } \\
\text { output } \\
\text { variable }\end{array}$} & \multicolumn{6}{|c|}{ Scenario SRESa2 } \\
\hline & Intercept & $p$-value & Slope & p-value & $\mathbf{R}^{2}$ & $\begin{array}{c}\text { Year to year } \\
\text { difference median }\end{array}$ \\
\hline basin_ppt & -0.0546 & $<2 \mathrm{e}-16$ & 0.00004 & $<2 \mathrm{e}-16$ & 0.8525 & 0.00005 \\
\hline basin_tmax & -86.9618 & $<2 \mathrm{e}-16$ & 0.07276 & $<2 \mathrm{e}-16$ & 0.9808 & 0.07319 \\
\hline basin_tmin & -121.2000 & $<2 \mathrm{e}-16$ & 0.07783 & $<2 \mathrm{e}-16$ & 0.9778 & 0.08687 \\
\hline basin_potet & -0.3930 & $<2 \mathrm{e}-16$ & 0.00026 & $<2 \mathrm{e}-16$ & 0.9705 & 0.00027 \\
\hline basin_et & -0.0401 & $<2 \mathrm{e}-16$ & 0.00004 & $<2 \mathrm{e}-16$ & 0.8908 & 0.00004 \\
\hline basin_snow & 0.0964 & $<2 \mathrm{e}-16$ & -0.00004 & $<2 \mathrm{e}-16$ & 0.9637 & -0.00004 \\
\hline recharge & -0.0101 & 0.000001 & 0.00001 & 0.000000 & 0.4048 & 0.00001 \\
\hline CFGI_67 & 267.6514 & $<2 \mathrm{e}-16$ & -0.12454 & $<2 \mathrm{e}-16$ & 0.9832 & -0.11678 \\
\hline \multirow{2}{*}{$\begin{array}{c}\text { PRMS } \\
\text { output } \\
\text { variable }\end{array}$} & \multicolumn{6}{|c|}{ Scenario SRESb1 } \\
\hline & Intercept & p-value & Slope & p-value & $\mathbf{R}^{2}$ & $\begin{array}{c}\text { Year to year } \\
\text { difference median }\end{array}$ \\
\hline basin_ppt & 0.0231 & $9.48 \mathrm{E}-07$ & $6.35 \mathrm{E}-06$ & 0.00373 & 0.09472 & 0.000012 \\
\hline basin_tmax & -36.1800 & $<2 \mathrm{e}-16$ & 0.04754 & $<2 \mathrm{e}-16$ & 0.9868 & 0.04358 \\
\hline basin_tmin & -60.1398 & $<2 \mathrm{e}-16$ & 0.04752 & $<2 \mathrm{e}-16$ & 0.9890 & 0.04372 \\
\hline basin_potet & -0.1593 & $<2 \mathrm{e}-16$ & 0.00015 & $<2 \mathrm{e}-16$ & 0.9776 & 0.00014 \\
\hline basin_et & 0.0026 & 0.471 & $1.44 \mathrm{E}-05$ & $2.3 \mathrm{E}-12$ & 0.4413 & $2.65 \mathrm{E}-05$ \\
\hline basin_snow & 0.0776 & $<2 \mathrm{e}-16$ & $-3.4 \mathrm{E}-05$ & $<2 \mathrm{e}-16$ & 0.9764 & $-3.5 \mathrm{E}-05$ \\
\hline recharge & 0.0202 & $<2 \mathrm{e}-16$ & $-7.8 \mathrm{E}-06$ & $<2 \mathrm{e}-16$ & 0.5993 & $-1.4 \mathrm{E}-05$ \\
\hline CFGI_67 & 185.2283 & $<2 \mathrm{e}-16$ & -0.08374 & $<2 \mathrm{e}-16$ & 0.9598 & -0.05484 \\
\hline
\end{tabular}


(SRESa1b, table 2). Because several of the data plots violate the assumption that the errors are random and that a linear model for trend may not be appropriate, the summary statistic of the median of the year-to-year difference was added to table 5, a value similar to the slope of the linear regression but without any underlying assumptions.

The seasonality of the watershed model simulation results can be visualized with boxplots of the monthly results for all the GCMs and emission scenarios for selected future years. Precipitation is highly variable by month in simulations for 2030, 2060, and 2090 (fig. 23), but the median values in winter months, December through March, generally increase into the future with less change evident in the remaining months. Air temperature shows a steady increase in future years for all months (fig. 24). Increased precipitation should increase recharge, but opposing this recharge gain is the warming air temperatures, which increases the amount of evapotranspiration, thus reducing soil moisture and the water available to recharge the groundwater reservoir. This interaction between increased precipiation and evapotranspiration, and how it affects recharge, can be seen in the monthly boxplots for the basin_soil_to_gw model output (ig. 25). The basin_soil_to_gw variable accounts for more than 99 percent of the simulated recharge in the Upper Crab Creek model. Early winter precipitation in November and December generally replenishes the dry soils before the moisture contributes to large amounts of recharge. Simulated recharge is greatest in the months of January through March when soil moisture storage has been satisfied, precipitation is relatively high, and temperature is relatively low. The median values of monthly recharge show an increase in recharge in the future for the months of December and January, and a decrease in March (fig. 25). Overall, however, there is no significant trend in the annual data (fig. 21, table 5).

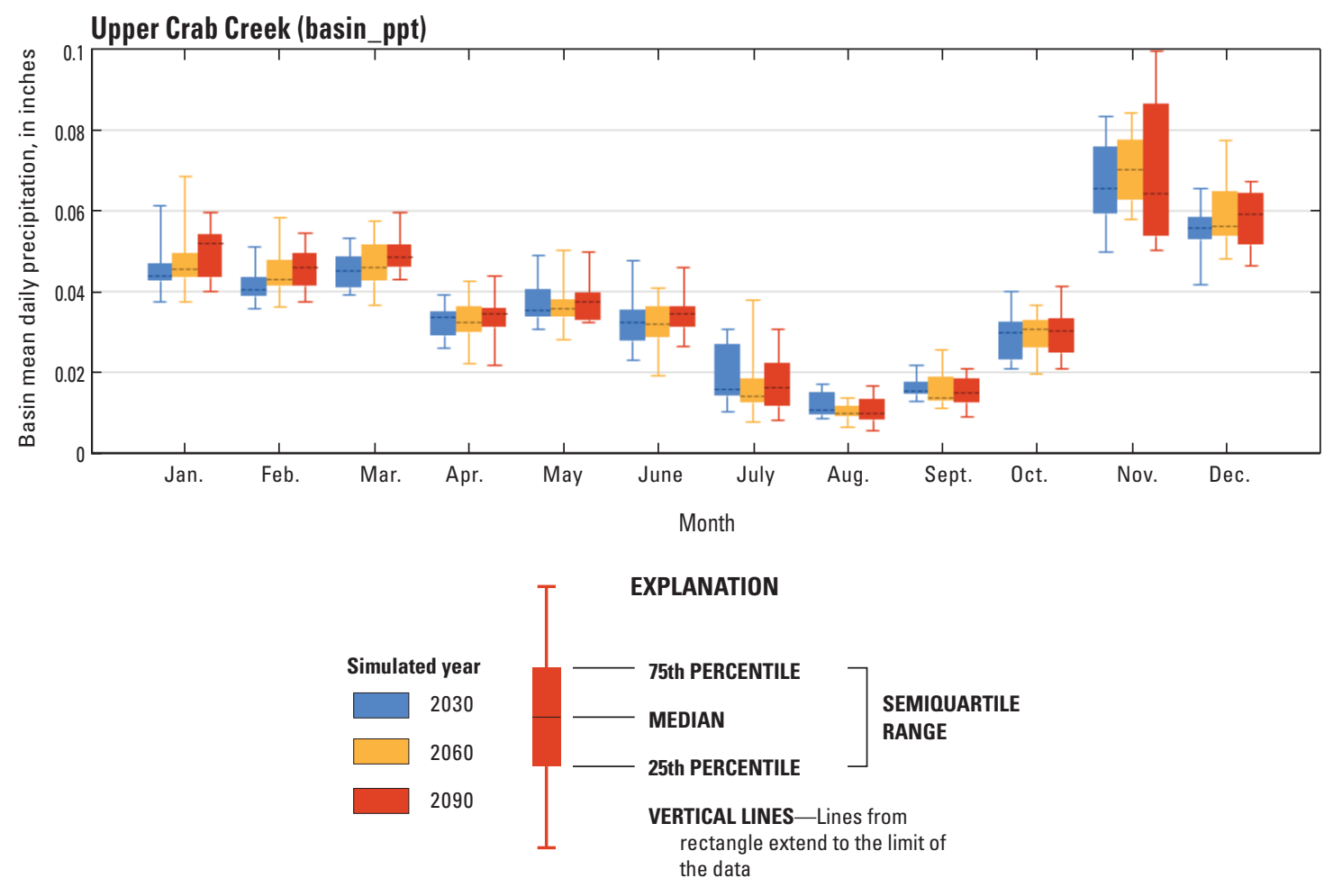

Figure 23. Basin mean daily precipitation input to the Upper Crab Creek model for each month for three future periods averaged for five global circulation models and three emission scenarios. 

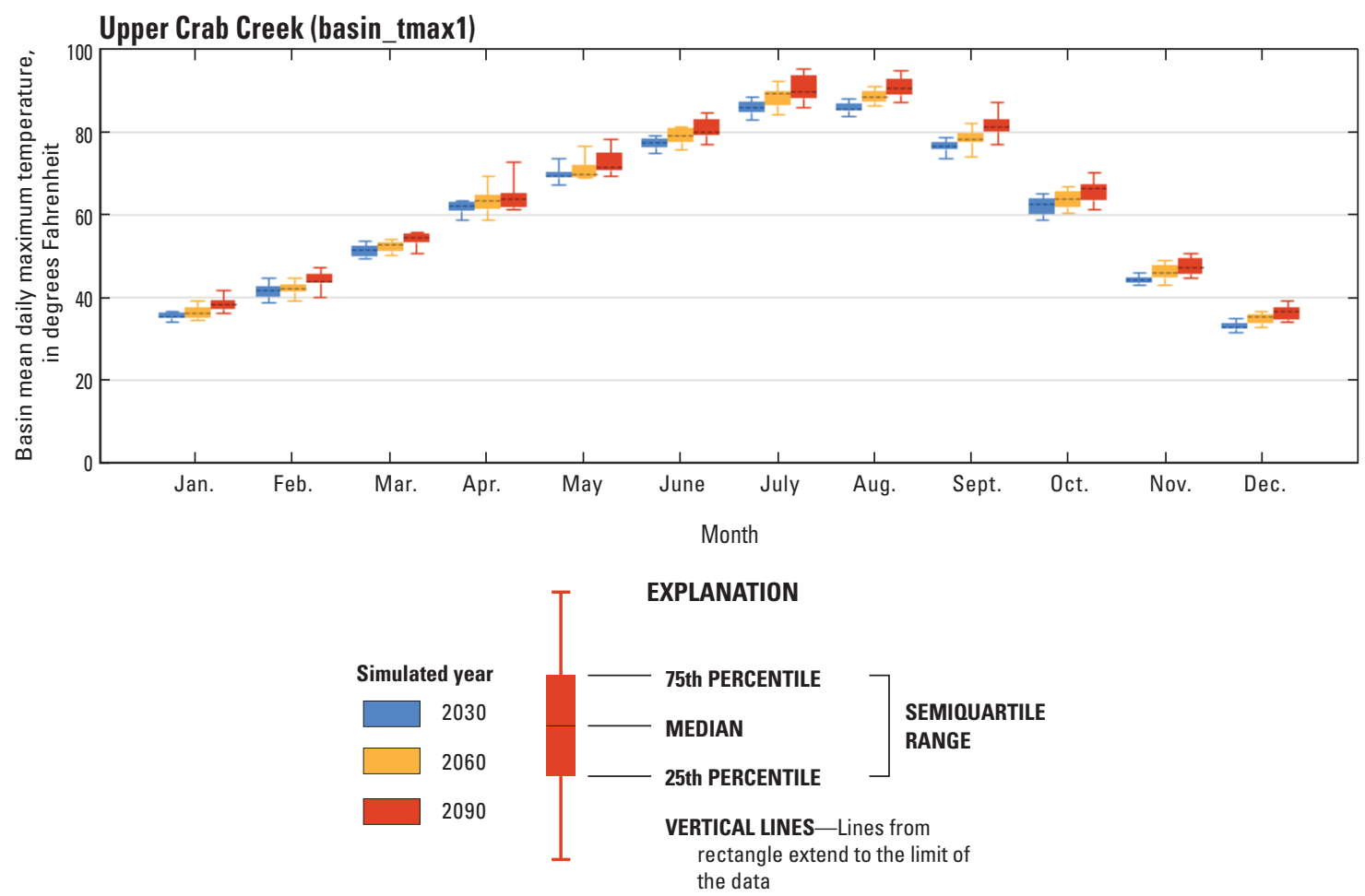

Figure 24. Basin-averaged daily maximum air temperature input to the Upper Crab Creek model for three future periods averaged for five global circulation models and three emission scenarios.

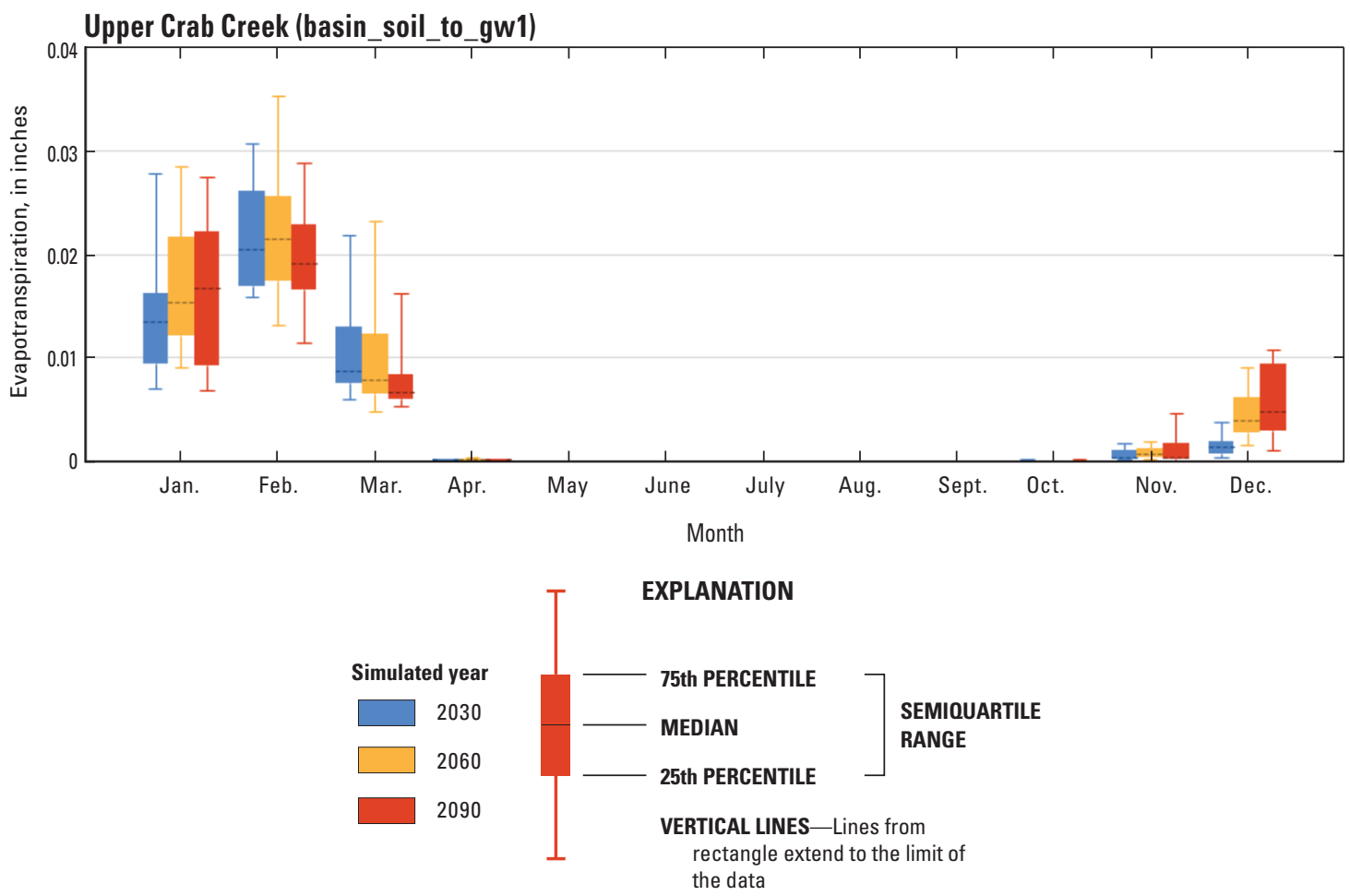

Figure 25. Basin-averaged simulated daily soil moisture flow to groundwater that is output from the Upper Crab Creek model for three future periods averaged for five global circulation models and three emission scenarios. 
Despite the fact that the trend models are not perfect, several trends and no trends are clear. If these emission scenarios are realistic predictions of the future trends, and the downscaling and model representations are accurate, there will be a steady increase in air temperature from 3.7 to $6.1^{\circ} \mathrm{F}$ average increase in the daily maximum temperature for the three emission scenarios from 2008 to 2094 and with a 3.7 to $6.8^{\circ} \mathrm{F}$ average increase in the daily minimum temperature for the same scenarios and time period for the Columbia Plateau. Precipitation is less steady and more variable than temperature but shows a general increasing trend, especially in the winter months. With the increase in precipitation into the future for the Columbia Plateau, recharge would be expected to increase, but air temperature is also increasing, which causes an increase in evapotranspiration that counteracts the increase in precipitation in making water available for recharge. With the increase in air temperature, the average CFGI index decreases, indicating a decrease in frozen ground, but snow cover, an insulation blanket for the soil, also decreases with warmer temperatures. Within the limitations of the watershed model to simulate frozen ground with a simple temperature-snow cover index (CFGI), model simulations sorted out the complex interactions of air temperature, frozen ground, snow cover, and precipitation that influence recharge, and provided estimates of the trend or no trend in recharge for possible future climates. This analysis for upper Crab Creek Basin showed no significant trend in the recharge data.

\section{Reynolds Creek Simulation Results}

The analysis for examining the change in recharge for Reynolds Creek for future possible climates was simplified to isolate only the effects of increasing air temperatures for two periods in the future and did not consider changes to precipitation or solar radiation, which are difficult to estimate. The Reynolds Creek Basin differs from the upper Crab Creek Basin because it contains more relief and more streamflow and meteorological data are available. The spatial aspect of how recharge and other hydrological variables change with the selected future climate scenarios can be shown by mapping the model results to individual HRUs (figs. $\underline{26}-\underline{28}$ ). The mean and median values of the entire basin show a modest decrease in recharge from the baseline model to the 2040 model (1.0 percent) and to the 2080 model ( 4.3 percent), despite much larger changes in the mean annual number of days when CFGI is greater than 50 , snow-water equivalent, and snow cover (table 6). The change in mean annual recharge from the baseline model to the 2080 model is only 0.13 or about
60 percent of the increase in the loss of moisture due to the increase in actual evapotranspiration (AET) from the baseline model to the 2080 model. Much of the decrease in recharge, therefore, may be due to the loss of available moisture in the soil and not the dramatic changes in snow cover and frozen ground.

Spatially, simulated recharge showed a wide range of values that were greatest in the highest elevations where snowfall and precipitation is greatest in all three model simulations. However, the changes in recharge between model runs are difficult to see in the maps (fig. 26) because of the modest changes overall. More clear changes can be seen in frozen ground and snow cover. The CFGI $>50$ variable was an indication of frozen ground and showed significant changes in the lower-elevation area of the basin in the northeast. The baseline model showed a mean annual value of about 50-70 days that decreased to values of about 20-30 days in the 2040 model and less than 20 days in the 2080 model (fig. 26).

Two competing changes in climate that affect the amount of time that soil is frozen show significant change in the future scenarios of climate. As time progresses, snow-cover and its inherent thermal insulation, which can keep soil thawed shows a dramatic reduction, especially in the mid-elevation zones of the basin (fig. 27), a phenomenon which is expected to increase the occurrence of frozen soils. The effects of this thermal insulation can be seen in the CFGI $>50$ map (fig. 26) for the baseline model where the smallest values of CFGI $>50$ are in the southern part of the basin in the highest elevations with the most snow cover (fig. 27). The second climate change is the increase in air temperatures in future scenarios (uniformly applied across the basin in the simulations) that directly affects soil temperatures and would be expected to decrease the occurrence of frozen soils. The results of these simulations suggest that the influence of the change in air temperature is winning over the influence of decreased snow cover to alter the occurrence of frozen ground in the Reynolds Creek Basin. Because precipitation was held constant for these simulations, AET is an important variable that affects the amount of moisture available for recharge. A general increase in AET in future scenarios in the basin was because of the increase in air temperature, but in the southern high-elevation part of the basin where the snowpack is the greatest, a general decrease in AET in the future scenarios was simulated (fig. 28). Simulated AET includes sublimation from the snow pack, and as the snow pack decreases in future scenarios, AET decreases. Mean daily soil moisture is greatest in the wettest part of the basin and shows only subtle changes in the future scenarios over the baseline conditions (fig. 28). 

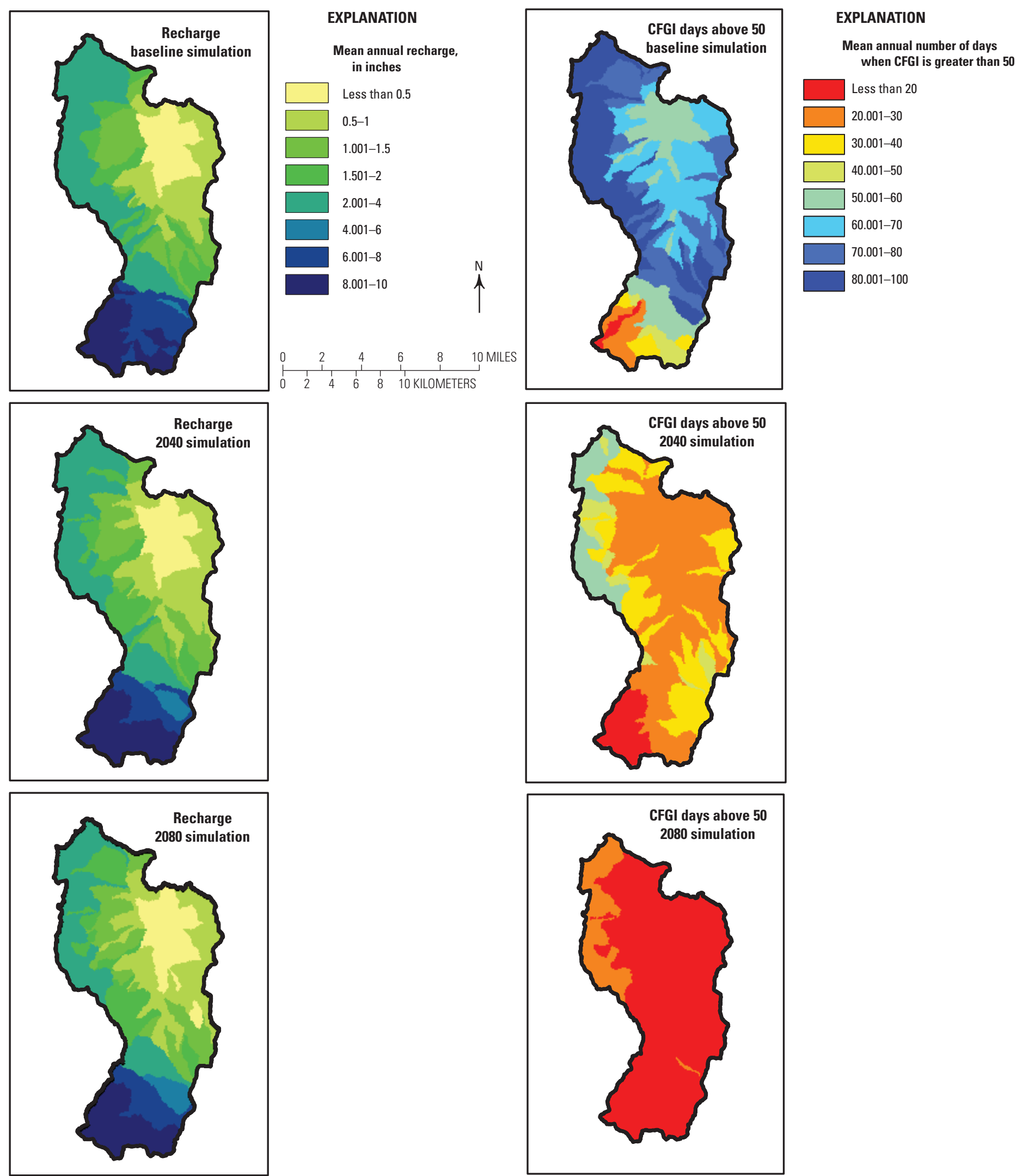

Figure 26. Simulated mean annual recharge and mean annual number of days when the continuous frozen ground index (CFGI) is greater than 50 for Reynolds Creek Basin, Snake River Plain, Idaho, for baseline, 2040, and 2080. Baseline period is 1988-99. 

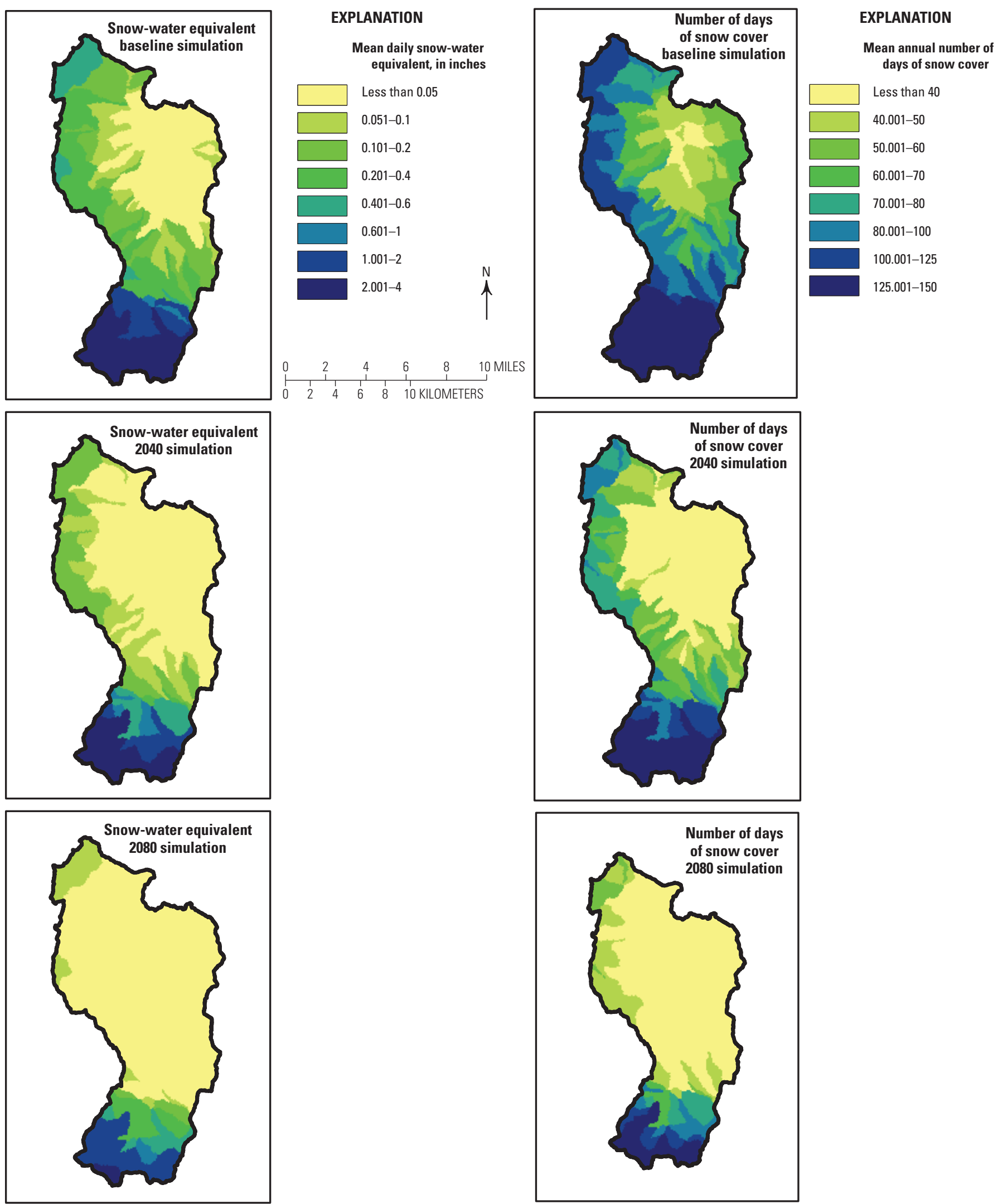

Figure 27. Simulated mean daily snow-water equivalent and mean annual number of days of snow cover for Reynolds Creek Basin, Snake River Plain, Idaho, for baseline, 2040, and 2080. Baseline period is 1988-99. 

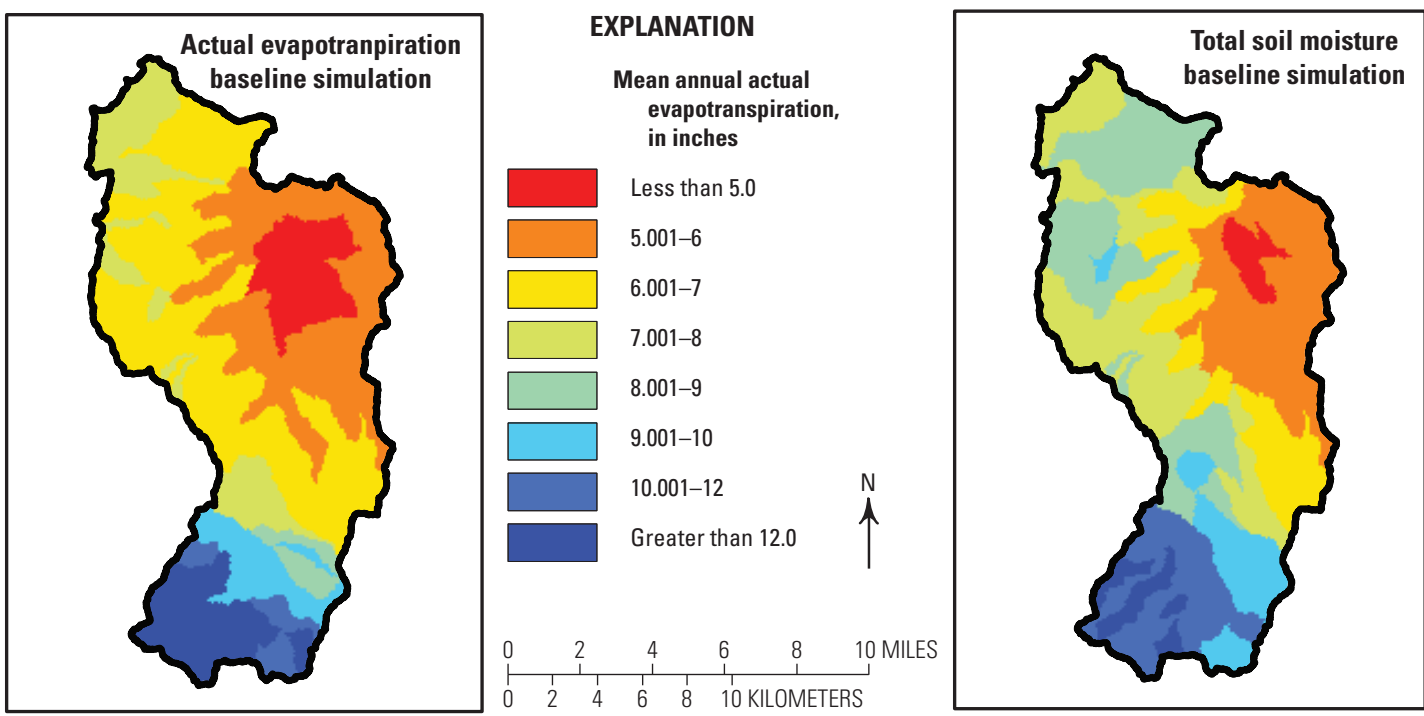

EXPLANATION
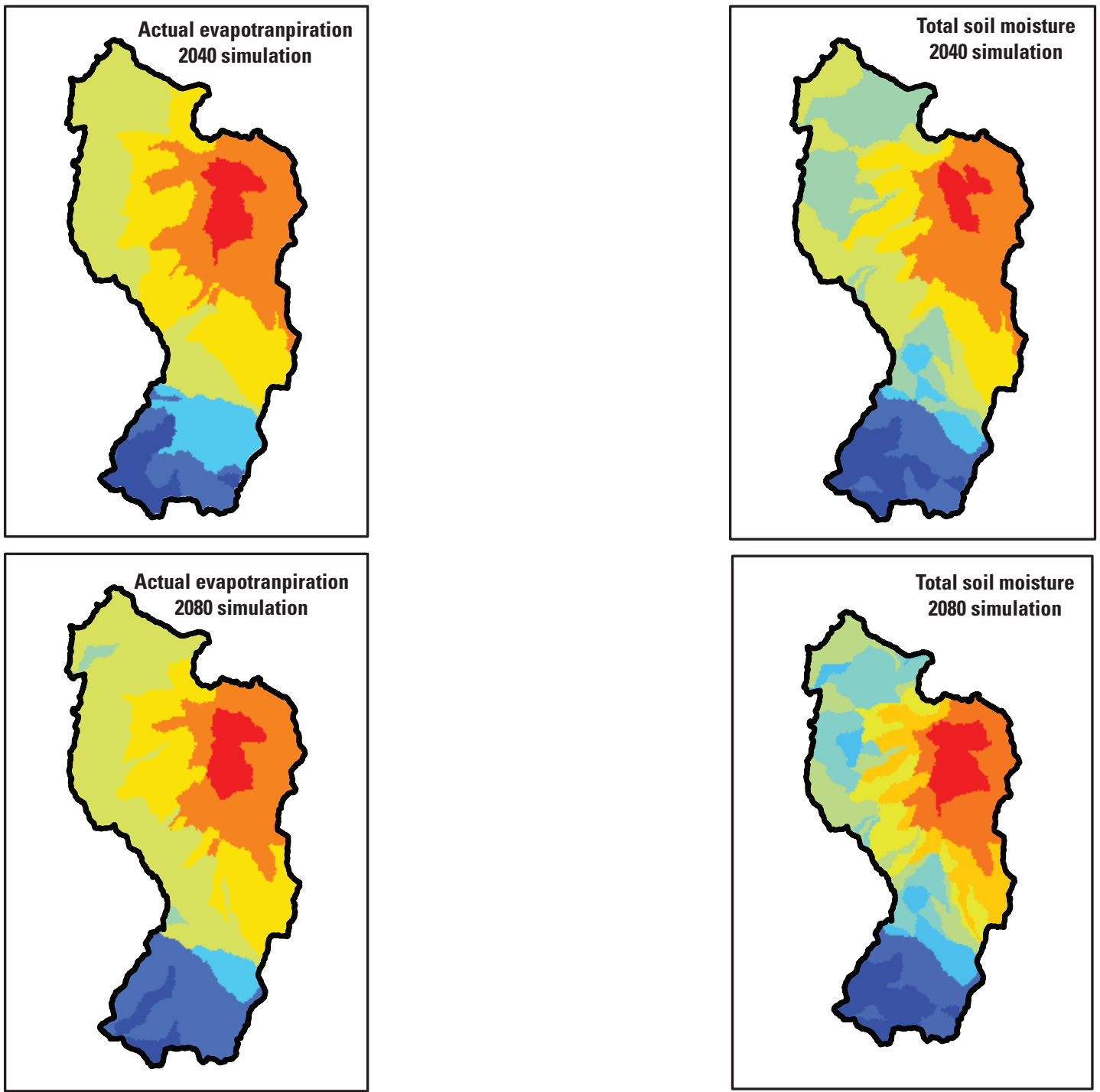

Figure 28. Simulated mean annual actual evapotranspiration and mean daily total soil moisture for Reynolds Creek Basin, Snake River Plain, Idaho, for baseline, 2040, and 2080. Baseline period is 1988-99. 
Table 6. Simulated recharge, Continuous Frozen Ground Index, snow-water equivalent, snow cover, actual evapotranspiration, runoff, and soil moisture for Reynolds Creek Basin, Snake River Plain, Idaho, for baseline, 2040, and 2080.

[Baseline period is 1988-99. Abbreviations: HRU, Hydrologic Response Unit; CFGI, Continuous Frozen Ground Index]

\begin{tabular}{lccccccc}
\hline Model run & $\begin{array}{c}\text { Mean annual } \\
\text { recharge } \\
\text { (inches) }\end{array}$ & $\begin{array}{c}\text { Median HRU value } \\
\text { of mean annual } \\
\text { number of days } \\
\text { with the CFGl } \\
\text { greater than 50 }\end{array}$ & $\begin{array}{c}\text { Mean daily } \\
\text { snow-water } \\
\text { equivalent } \\
\text { (inches) }\end{array}$ & $\begin{array}{c}\text { Median HRU value } \\
\text { of mean annual } \\
\text { number of days } \\
\text { with snow cover }\end{array}$ & $\begin{array}{c}\text { Mean annual actual } \\
\text { evapotranspiration } \\
\text { (inches) }\end{array}$ & $\begin{array}{c}\text { Mean annual } \\
\text { runoff } \\
\text { (inches) }\end{array}$ & $\begin{array}{c}\text { Mean daily total } \\
\text { soil moisture } \\
\text { (inches) }\end{array}$ \\
\hline Baseline & 3.03 & 68.8 & 0.707 & 80.5 & 7.27 & 2.42 & 0.784 \\
2040 & 3.00 & 11.5 & 0.395 & 50.3 & 7.35 & 2.33 & 0.787 \\
2080 & 2.90 & 6.4 & 0.191 & 29.5 & 7.49 & 2.07 & 0.766 \\
\hline
\end{tabular}

\section{Summary}

One of the goals of this study was to test a methodology or proof of concept to monitor large regional areas of seasonally frozen ground in the Pacific Northwest. Satellite remote sensing provided a method to determine whether ground is snow-covered or bare, and if the ground is bare, whether or not it is frozen. For the 21 year record of satellite data (1989-2009), the annual average number of days ground was snow-covered or frozen showed no trends, except in the Snake River Plain, which showed an increase in the frozen ground early in the record. In regions of seasonally frozen ground, the change between these ground conditions is intermittent and highly variable, both spatially and particularly temporally. A statistical technique, regime-shift analysis, was applied to each annual time series to determine when significant thermal regime changes occurred. While satellite remote sensing cannot specifically monitor frozen ground once it is covered by snow, the methods described in this report used for this study prove that these large regional areas can be successfully monitored for seasonally frozen ground by remote sensing when combined with regime-shift analysis.

One of the purposes of this study was to explore the linkages between seasonally frozen ground, climate change, and groundwater recharge. The study used a watershed model to explore the details of the hydrologic processes involved in the recharge of frozen ground. The working hypothesis going into the study suggested that where frozen ground occurs, there is less groundwater recharge because frozen ground generally rejects potential recharge. Within the context of climate change and a general increase of air temperatures, a reduction in the amount of time that ground is frozen might be expected, with a subsequent increase in recharge. However, the hypothesis is somewhat complicated by the influence of snow as a thermal insulator to the soil. Increasing air temperature in future climates could reduce the amount of snow cover over current conditions and likely increase the amount of frozen ground, thereby decreasing recharge.
The U.S. Geological Survey Precipitation Runoff Modeling System (PRMS) watershed model was used in this study to simulate frozen ground and recharge in two representative basins to try to sort out these complex interactions in the context of how recharge might change under future climate scenarios. An existing model for upper Crab Creek (Upper Crab Creek model) was used to represent the relatively low relief landscape of the Columbia Plateau, and a model constructed for this study in the Reynolds Creek Experimental basin on the eastern mountainous edge of the Snake River Plain represented a basin with more relief. In these semi-arid regions of seasonally frozen ground in the Pacific Northwest, nearly all the water available for recharge from precipitation occurs between October and March, when precipitation is most abundant and frozen ground is commonplace.

Within the PRMS watershed model, frozen ground is simulated with a Continuous Frozen Ground Index (CFGI), an index algorithm that shunts all water available for infiltration to a surface-water flow path, thus eliminating any simulated recharge once a threshold index value is reached. A more detailed energy model of water infiltration under frozen soil conditions that is spatially distributed based on soil characteristics and land use would provide more accurate simulations, but was not available in the selected watershed model. However, the CFGI algorithm and the watershed model provided a relative change in the occurrence of frozen ground and recharge that was used to simulate a likely change for the prescribed future climate scenarios.

Downscaled precipitation and air temperature time series from existing global circulation models for several emission scenarios provided the input to the Upper Crab Creek model for future recharge simulations. The future climate scenarios showed a steady increase in air temperature over time, resulting in a reduced occurrence of frozen ground. As temperature increased, a smaller percentage of precipitation was simulated as snow. Annual precipitation also increases in future climate scenarios over baseline (water years 1984-2000) simulations, thus increasing the amount of water available for recharge. At the same time, 
actual evapotranspiration increased and tended to offset the increase in precipitation, resulting in no significant increase or decrease in simulated recharge over baseline simulations. In the Reynolds Creek Basin simulations, a simplified approach was used to simulate future climates. Precipitation was held constant in future scenarios and air temperature was increased seasonally $3.06-4.86^{\circ} \mathrm{F}$ for representation of 2040 climate conditions and $5.76-8.82^{\circ} \mathrm{F}$ for representation for 2080 climate conditions. Simulated recharge was reduced by 1.0 percent for 2040 model runs and reduced by 4.3 percent for 2080 model runs. Simulation results showed dramatic change in snow cover and frozen ground, but also showed a loss of available moisture, which may be the main reason for a decrease in recharge, rather than the soil moisture infiltration dynamics involved with frozen ground. Simulated recharge showed a wide range of values throughout the basin with the greatest in the highest elevations where snowfall and precipitation is greatest; however, changes over time were subtle because of the modest changes overall.

\section{References Cited}

Bureau of Reclamation, 2012, AgriMet-The Pacific Northwest Cooperative Agricultural Weather Network: Bureau of Reclamation database, accessed May 14, 2012, at http://www.usbr.gov/pn/agrimet/.

Burton, Dennis, Hanson, C.L., and Molnau, Myron, 1990, Frost distribution and occurrence on a rangeland watershed in southwest Idaho: Northwest Science, v. 64, no. 3, 140 p.

Cherkauer, K.A., and Lettenmaier, D.P., 1999, Hydrologic effects of frozen soils in the upper Mississippi River basin: Journal of Geophysical Research, v. 104, no. D16, p. $19,599-19,610$.

Engelmark, Helén, 1988, Rates of infiltration into frozen and unfrozen fine sand: Canadian Journal of Earth Science, v. 25 , p. $343-347$.

Garabedian, S.P., 1986, Application of a parameter-estimation technique to modeling the regional aquifer underlying the Eastern Snake River Plain, Idaho-A contribution of the Regional Aquifer-Systems Analysis Program: U.S. Geological Survey Water Supply Paper 2278, 60 p.

Goodrich, L.E., 1982, The influence of snow cover on the ground thermal regime: Canadian Geotech Journal, v. 19, p. 421-432.

Granger, R.J., Gray, D.M., and Dyck, G.E., 1984, Snowmelt infiltration to frozen prairie soils: Canadian Journal of Earth Sciences, v. 21, p. 669-677.
Gray, D.M., Toth, Brenda, Zhao, Litong, Pomeroy, J.W., and Granger, R.J., 2001, Estimating areal snowmelt infiltration into frozen soils: Hydrological Processes, v. 15, p. 3,095-3,111.

Hansen, A.J., Vaccaro, J.J., and Bauer, H.H., 1994, Groundwater flow simulation of the Columbia Plateau regional aquifer system, Washington, Oregon, and Idaho: U.S. Geological Survey Water-Resources Investigations Report 91-4187, 81 p., http://pubs.er.usgs.gov/publication/ wri914187.

Hanson, C.L., Marks, D., and Van Vactor, S.S., 2001, Longterm climate database, Reynolds Creek experimental watershed, Idaho, United States: Water Resources Research, v. 37, no. 11, p. 2,839-2,841.

Intergovernmental Panel on Climate Change, 2007, Summary for policymakers, in Solomon, S., Qin, D., Manning, M., Chen, Z., Marquis, M., Averyt, K.B., Tignor, M., and Miller, H.L., Climate change 2007-The physical science basis, Contributions of Working Group 1 to the Fourth Assessment Report of the Intergovernmental Panel on Climate Change: Cambridge and New York, Cambridge University Press, $18 \mathrm{p}$.

Larson, Emily, Wu, Joan, and McCool, Don, 2002, Continuous frozen ground index (CFGI) as an indicator for high erosion frozen soil events: Washington State University, Center for Multiphase Environmental Research Technical Report, accessed October 2004 at http://www.cmer.wsu.edu/ summer/larson.pdf.

Leavesley, G.H., Lichty, R.W., Troutman, B.M., and Saindon, L.G., 1983, Precipitation-runoff modeling systemUser's manual: U.S. Geological Survey Water-Resources Investigations Report 83-4238, 207 p., http://pubs.er.usgs. gov/publication/wri834238.

Lindholm, G.F., 1996, Summary of the Snake River plain regional aquifer-system analysis in Idaho and eastern Oregon: U.S. Geological Survey Professional Paper 1408-A, 59 p., http://pubs.er.usgs.gov/publication/ pp1408A.

Littell, J.S., Elsner, M.M., Mauger, G.S., Lutz, Eric, Hamlet, A.F., and Salathé, Eric, 2011, Regional climate and hydrologic change in the northern US Rockies and Pacific Northwest-Internally consistent projections of future climate for resource management: University of Washington, Climate Impacts Group project report, 102 p., accessed June 13, 2013, at http://cses.washington.edu/picea/ USFS/pub/Littell_etal_2010/. 
Markstrom, S.L., Hay, L.E., Ward-Garrison, C.D., Risley, J.C., Battaglin, W.A., Bjerklie, D.M., Chase, K.J., Christiansen, D.E., Dudley, R.W., Hunt, R.J., Koczot, K.M., Mastin, M.C., Regan, R.S., Viger, R.J., Vining, K.C., and Walker, J.F., 2012, An integrated watershed scale response to climate change for selected basins across the United States: U.S. Geological Survey Scientific Investigation Report 2011-5077, 142 p., http://pubs.er.usgs.gov/publication/ $\operatorname{sir} 20115077$.

Mastin, M.C., 2009, Watershed models for decision support for inflows to Potholes Reservoir, Washington: U.S. Geological Survey Scientific Investigations Report 2009-5081, 54 p., http://pubs.er.usgs.gov/publication/ $\operatorname{sir} 20095081$.

McDonald, K.C., Kimball, J.S., Njoku, E., Zimmermann, R., and Zhao, M., 2004, Variability in springtime thaw in the terrestrial high latitudes-Monitoring a major control on the biospheric assimilation of atmospheric $\mathrm{CO}_{2}$ with spaceborne microwave remote sensing: Earth Interactions, v. 8 , no. 20 , p. $1-23$.

Molnau, M., and Bissel, V.C., 1983, A continuous frozen ground index for flood forecasting, in Barnicle, R.G., and Carrol, T.R., Annual Western Snow Conference: Vancouver, Wash., Proceedings of the 51st Annual Meeting of the Western Snow Conference, p. 109-119.

Mote, P.W., and Salathé, E.P., Jr., 2010, Future climate in the Pacific Northwest: Climatic Change, v. 102, p. 29-50.

Nayak, A., Marks, D., Chandler, D.G., and Seyfried, M., 2010, Long-term snow, climate, and streamflow trends at the Reynolds Creek Experimental Watershed, Owyhee Mountains, Idaho, United States: Water Resources Research, v. 46, p. 1-15.

Pierson, F.B., Slaughter, C.W., and Cram, Z.K., 2001, Long-term stream discharge and suspended-sediment database, Reynolds Creek Experimental Watershed, Idaho, United States: Water Resources Research, v. 37, no. 11, p. $2,857-2,861$.

PRISM Climate Group, 2006, United States average monthly or annual precipitation, 1971-2000: Corvallis, Oreg., Oregon State University database, accessed August 9, 2012, at http://oldprism.nacse.org/products/matrix. phtml? vartype $=$ tmax\&view $=$ maps.

Rodionov, S.N., 2004, A sequential algorithm for testing climate regime shifts: Geophysical Research Letters., v. 21, no. L09204, 4 p.
Ruosteenoja, K., Carter, T.R., Jylhä, K., and Tuomenvirta, H., 2003, Future climate in world regions - An intercomparison of model-based projections for the new IPCC emissions scenarios: The Finnish Environment, v. 644, 81 p.

Shanley, J.B., and Chalmers, Ann, 1999, The effect of frozen soil on snowmelt runoff at Sleepers River, Vermont: Hydrological Processes, v. 13, p. 1,843-1,857.

Slaughter, C.W., Marks, Danny, Flerchinger, G.N., Van Vactor, S.S., and Burgess, Mike, 2001, Thirty-five years of research data collection at the Reynolds Creek experimental watershed, Idaho, United States: Water Resources Research, v. 37 , no. 11 , p. $2,819-2,823$.

U.S. Department of Agriculture, National Resource Conservation Service, 2009, National Water and Climate Center Soil Climate Analysis Network (SCAN):

U.S. Department of Agriculture brochure, accessed December 31, 2013, at http://www.wcc.nrcs.usda.gov/ publications/.

Viger, R.J., 2008, An overview of the GIS Weasel: U.S. Geological Survey Fact Sheet 2008-3004, 2 p., http://pubs. er.usgs.gov/publication/fs20083004.

Voss, F.D., and Mastin, M.C., 2012, Simulation of streamflows and basin-wide hydrologic variables over several climatechange scenarios, Methow River basin, Washington: U.S. Geological Survey Scientific Investigations Report 2012-5031, 18 p., http://pubs.er.usgs.gov/publication/ sir20125031.

Whitehead, R.L., 1994, Ground water atlas of the United States-Segment 7, Idaho, Oregon, Washington: U.S. Geological Survey Hydrologic Investigations Atlas 730-H, 31 p., http://pubs.er.usgs.gov/publication/ha730H.

Zhang, T., and Armstrong, R.L., 2001, Soil freeze/thaw cycles over snow-free land detected by passive microwave remote sensing: Geophysical Research Letters, v. 28, p. 763-766.

Zhang, T., and Armstrong, R.L., 2008, Toward development of a comprehensive frozen soil algorithm [abs.]: American Geophysical Union, Fall Meeting 2008, abstract \#H23F-1041.

Zhang, T., Armstrong, R.L., and Smith, Jeff, 2003, Investigation of the near-surface soil freeze-thaw cycle in the contiguous United States-Algorithm development and validation: Journal of Geophysical Research, v. 108, iss. D22, doi:10.1029/2003JD003530.

Zuzel, J.F., and Pikul, J.L., Jr., 1987, Infiltration into a seasonally frozen agricultural soil: Journal of Soil and Water Conservation, v. 42 , no. 6, p. 447-450. 


\section{Appendix A. Frozen Ground and Snow Cover in the Columbia Plateau and Snake River Plain, Idaho, Oregon, and Washington, Water Years 1989-2009}

The first set of color-coded maps show the 21 years (water years 1989-2009) of the annual number of days of frozen ground, and the second set of maps show the 21 years of the annual number of days of snow cover (SNOW DAY) derived from satellite remote sensing. Each pixel of data covers an area of $15.5 \times 15.5$ miles and is in one of the two regions in the study area-the Columbia Plateau (upper left of map) and the Snake River Plain.
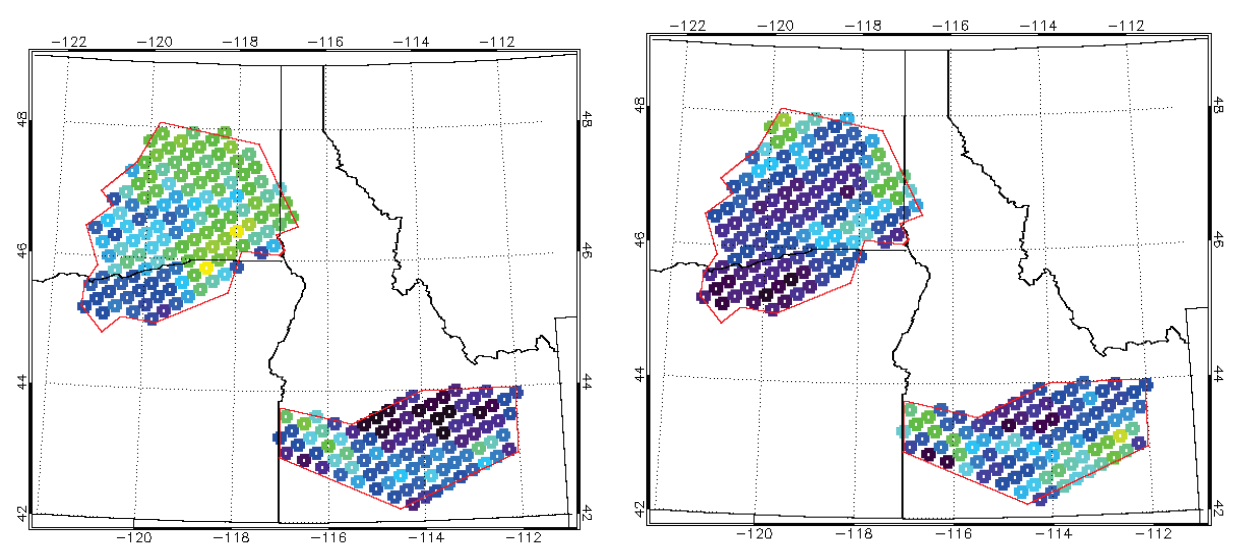

1989 FROZEN GROUND

1990 FROZEN GROUND
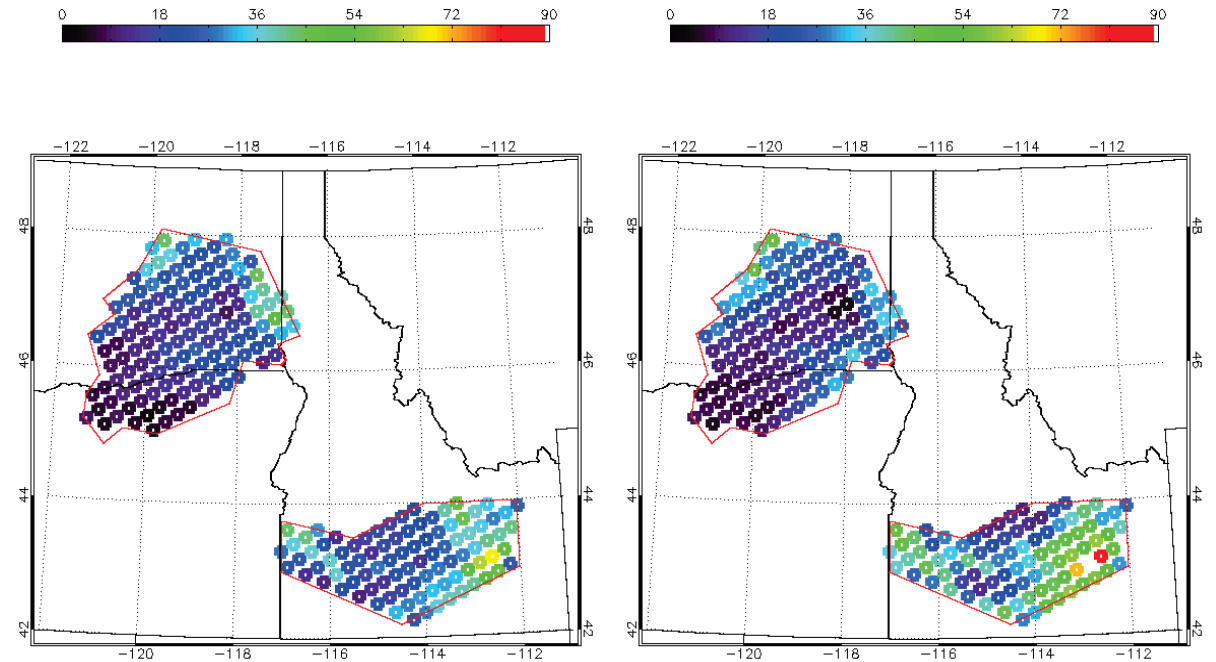

1991 FROZEN GROUND

1992 FROZEN GROUND 

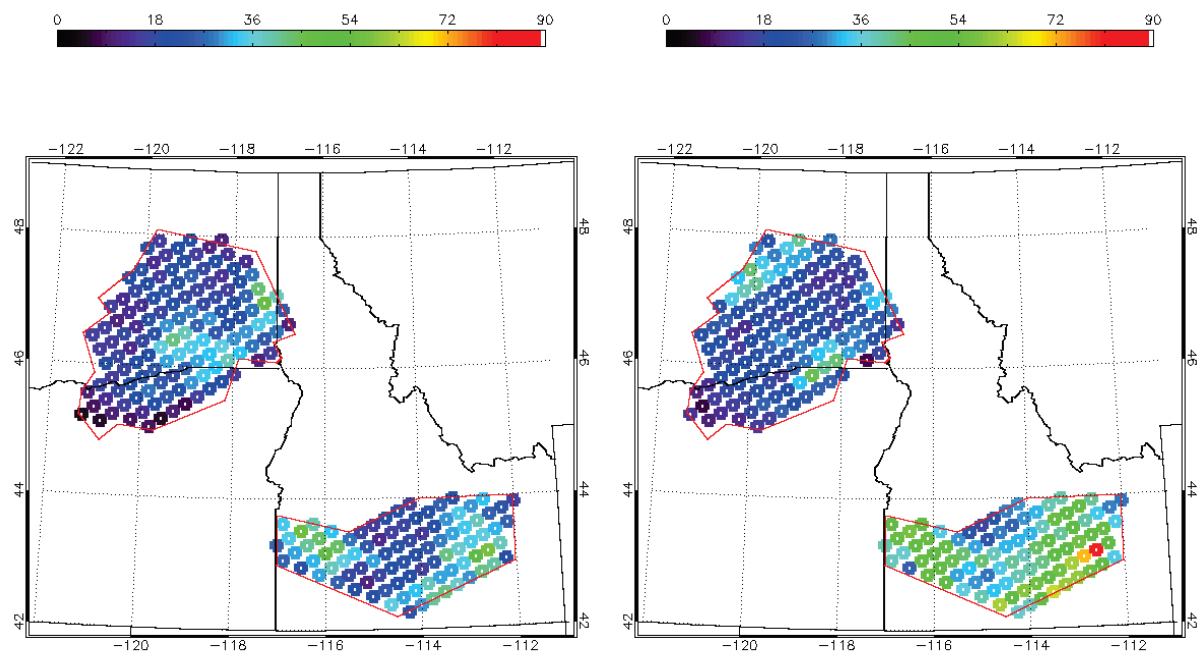

1993 FROZEN GROUND

1994 FROZEN GROUND
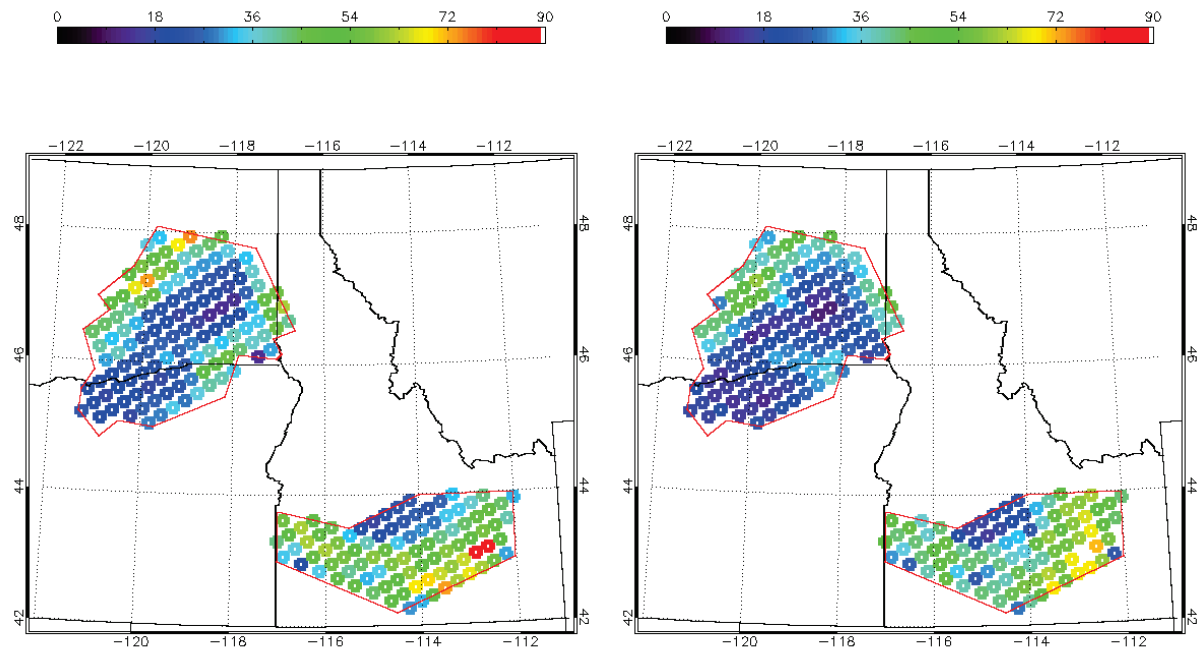

1995 FROZEN GROUND

1996 FROZEN GROUND 

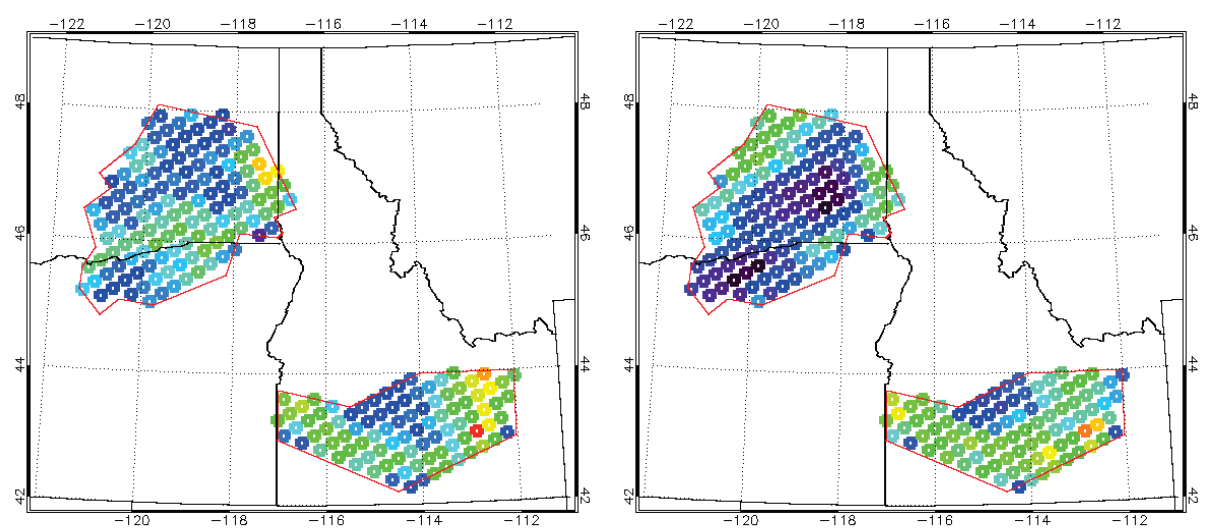

1997 FROZEN GROUND

1998 FROZEN GROUND
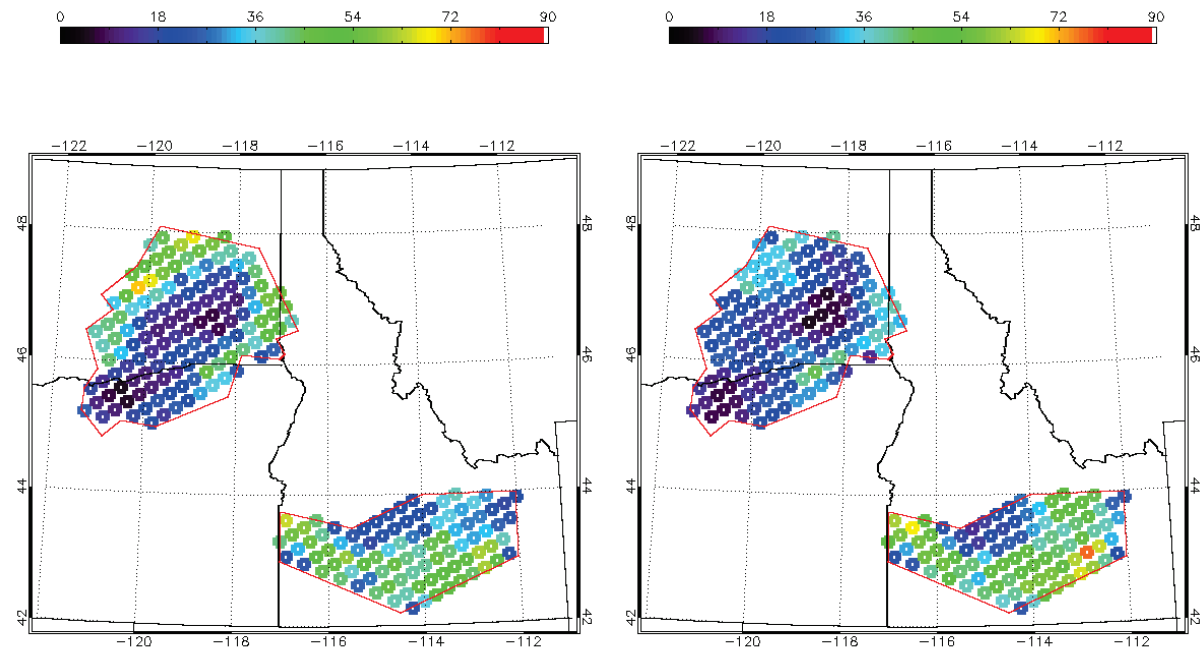

1999 FROZEN GROUND

2000 FROZEN GROUND 

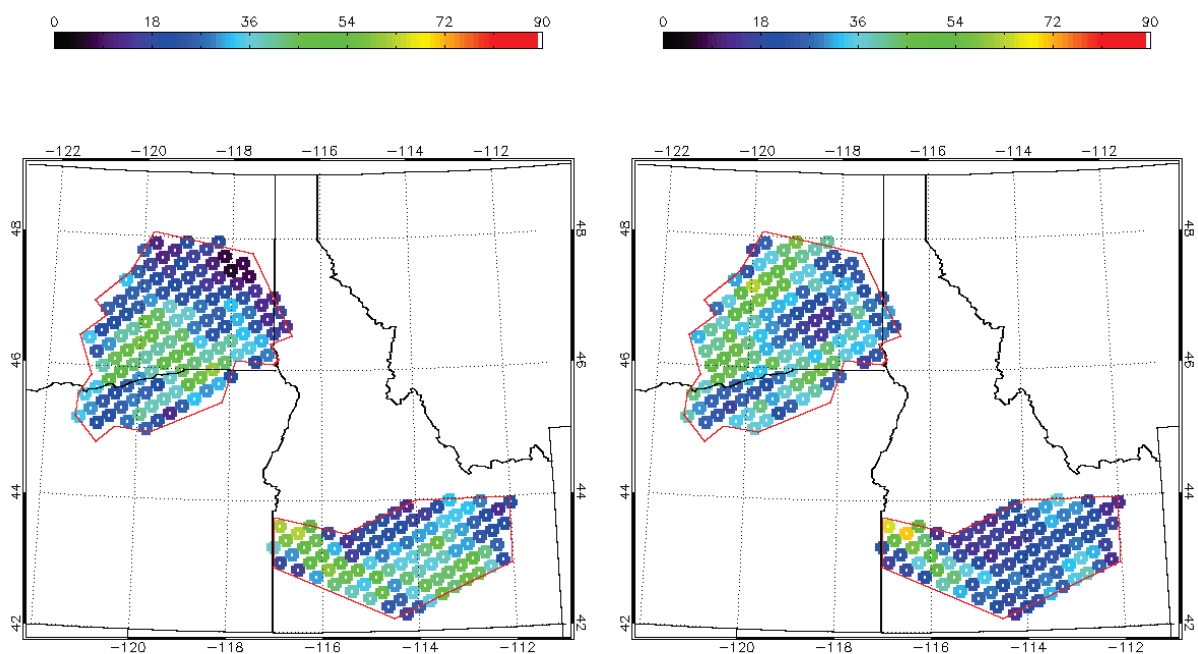

2001 FROZEN GROUND

2002 FROZEN GROUND
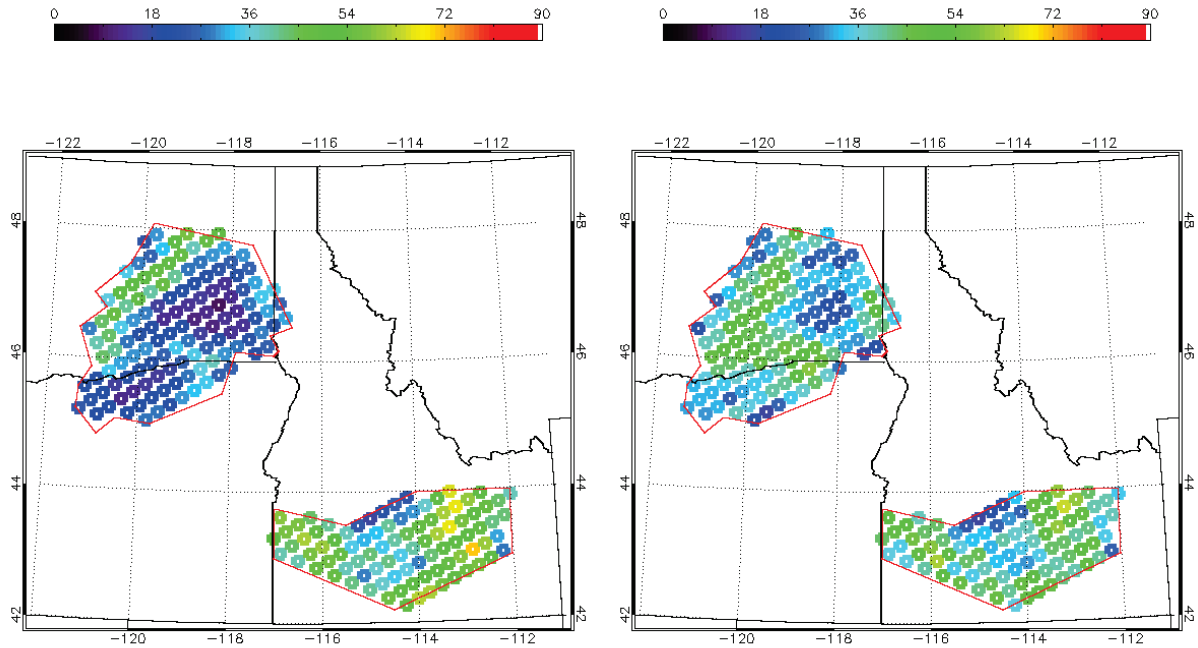

2003 FROZEN GROUND

2004 FROZEN GROUND 

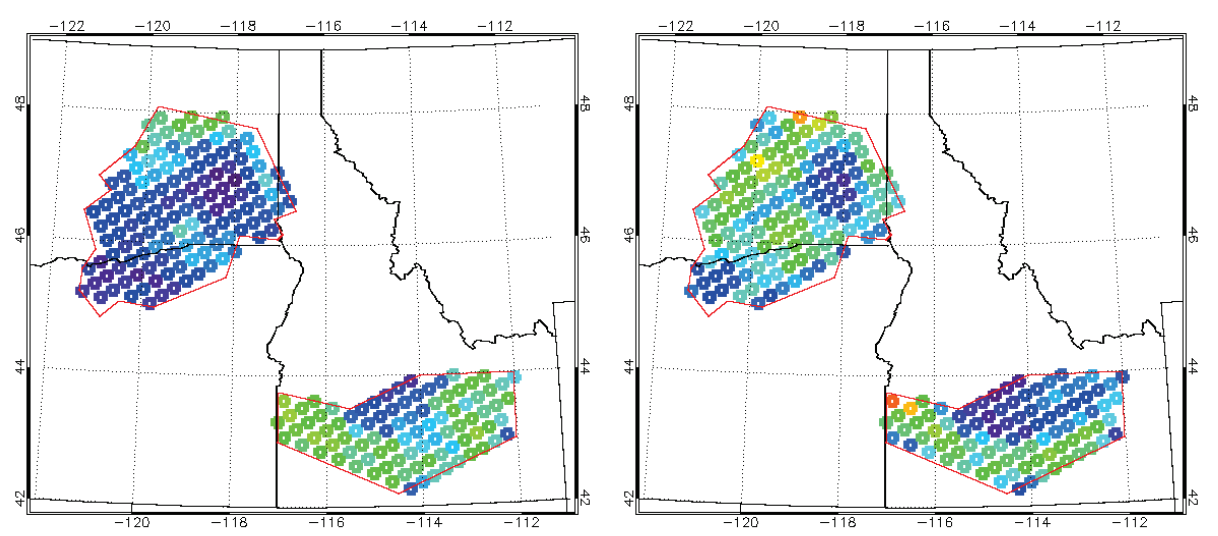

2005 FROZEN GROUND

2006 FROZEN GROUND
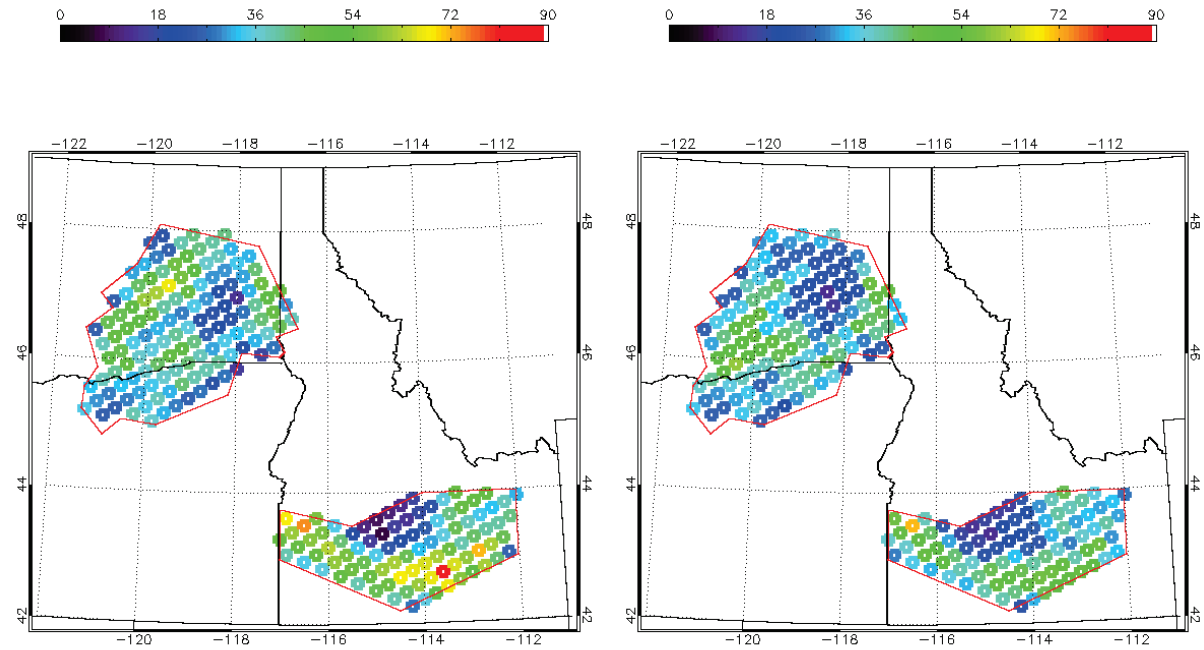

2007 FROZEN GROUND

2008 FROZEN GROUND 


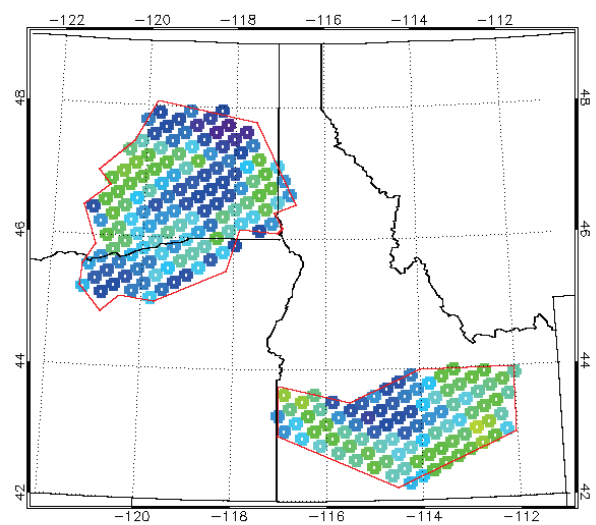

2009 FROZEN GROUND
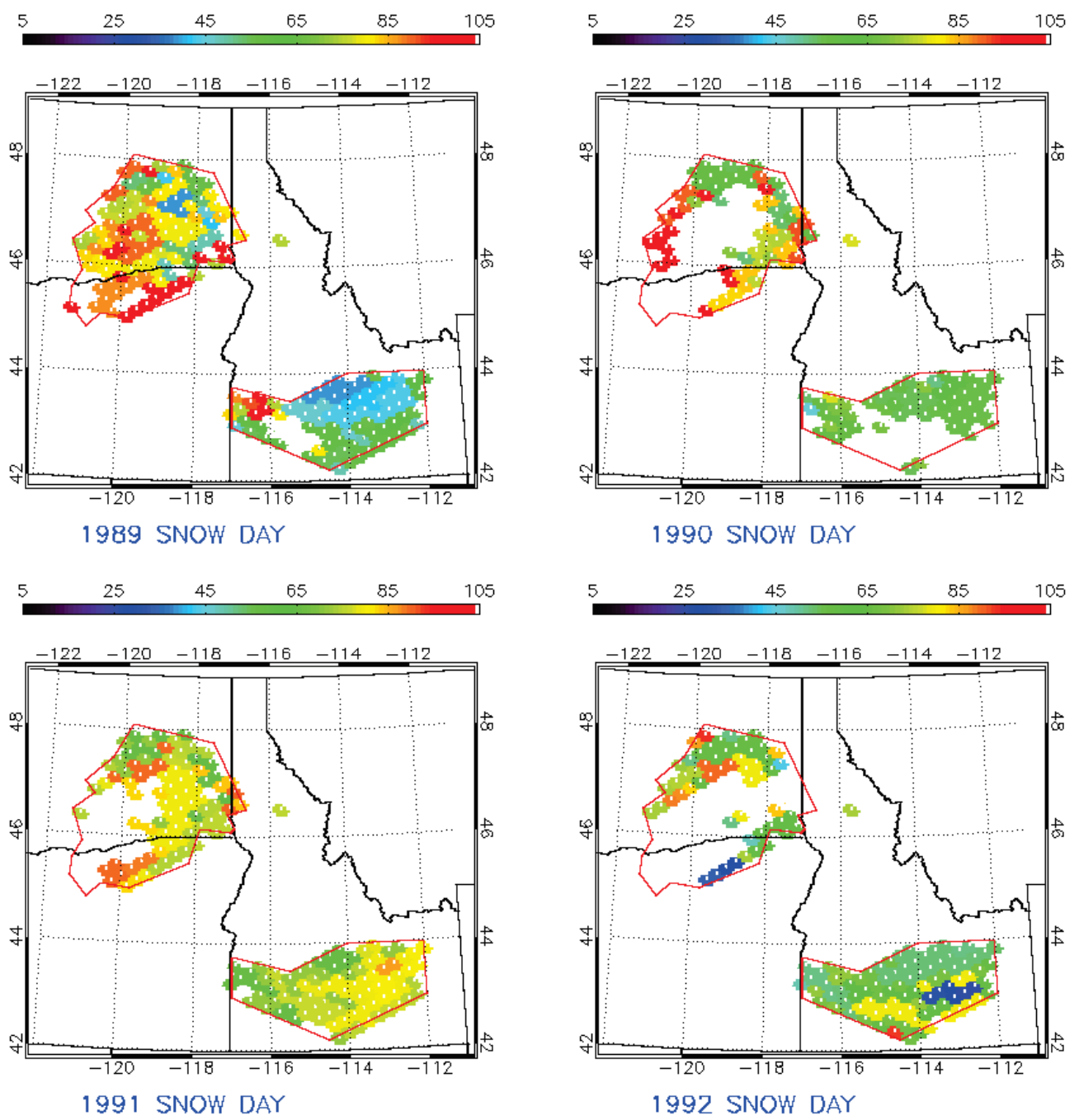

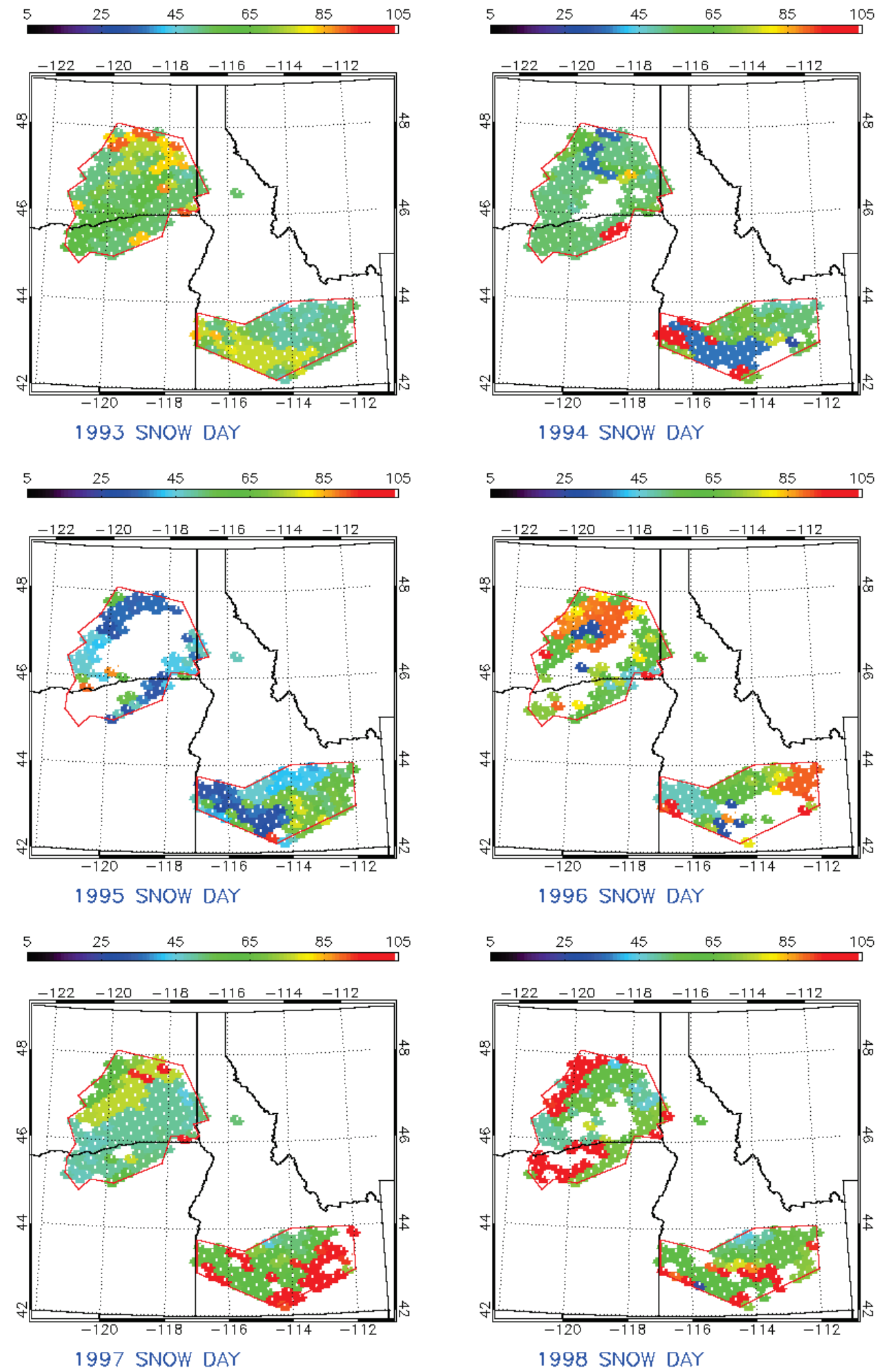

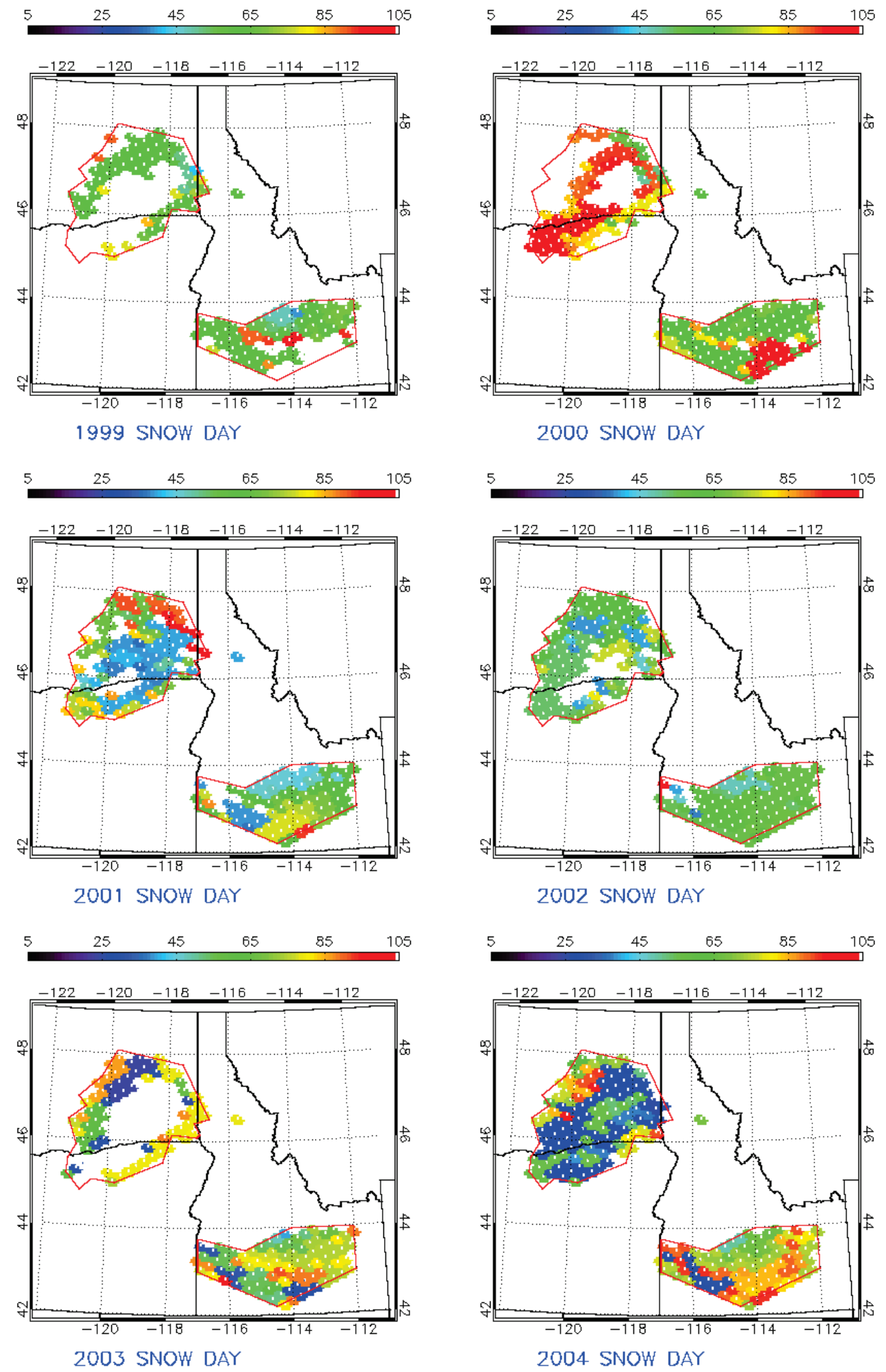

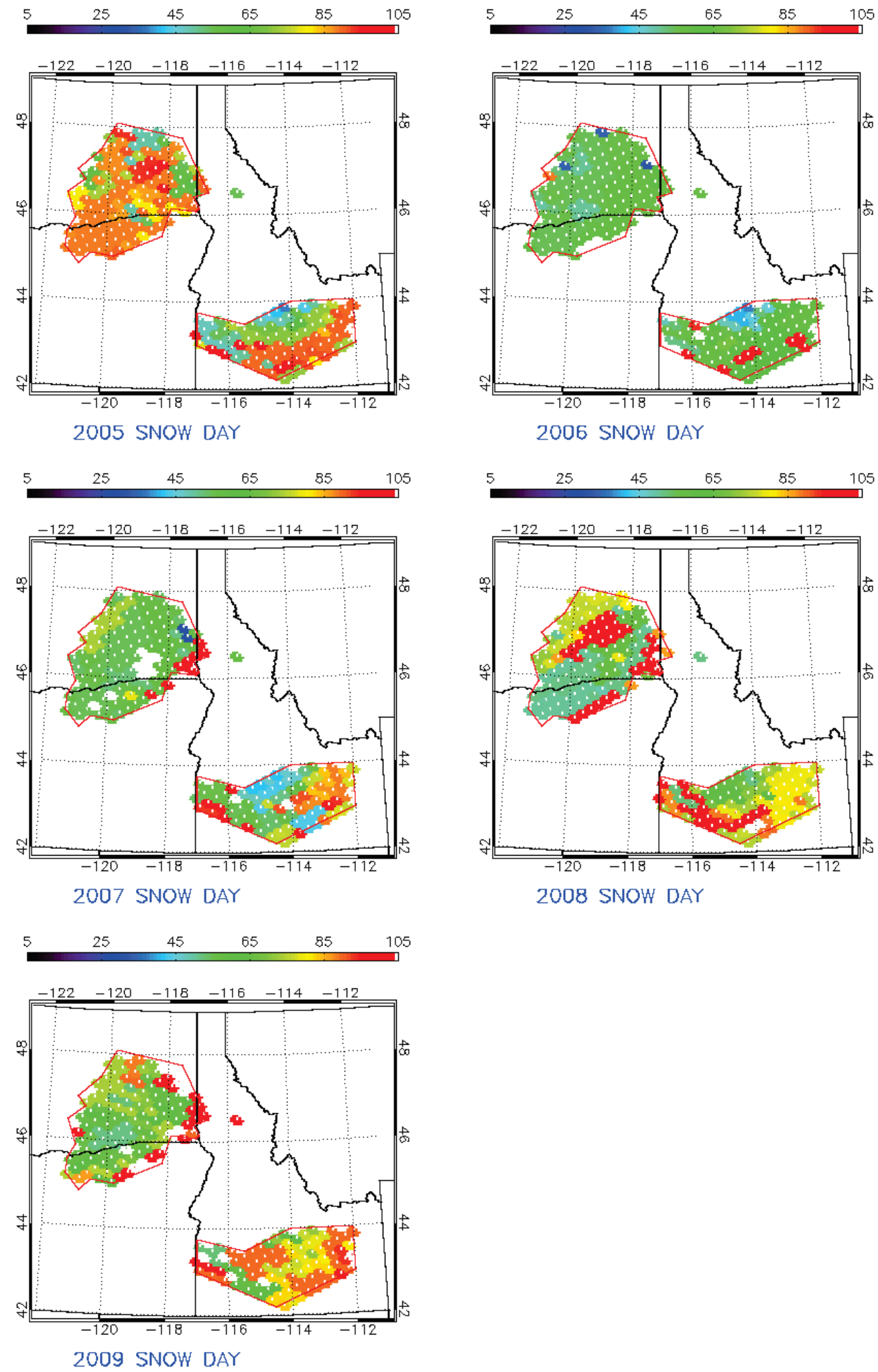


\section{Appendix B. Water-Year-Day of First Day of Frozen Ground and First Day of Snow Cover in the Columbia Plateau and Snake River Plain, Idaho, Oregon, and Washington, Water Years 1989-2009}

The first set of color-coded maps show the 21 years (water years 1989-2009) of the water-year day when the ground first becomes frozen as determined by regime analysis of processed satellite remote sensing data (FRZ GROUND) and the second set of maps show the 21 years of the water-year day when the first snow cover begins using regime analysis of processed satellite remote sensing data (SNOW DAY). Each pixel of data covers an area of $15.5 \times 15.5$ miles and is in one of the two regions in the study area - the Columbia Plateau (upper left of map) and the Snake River Plain.
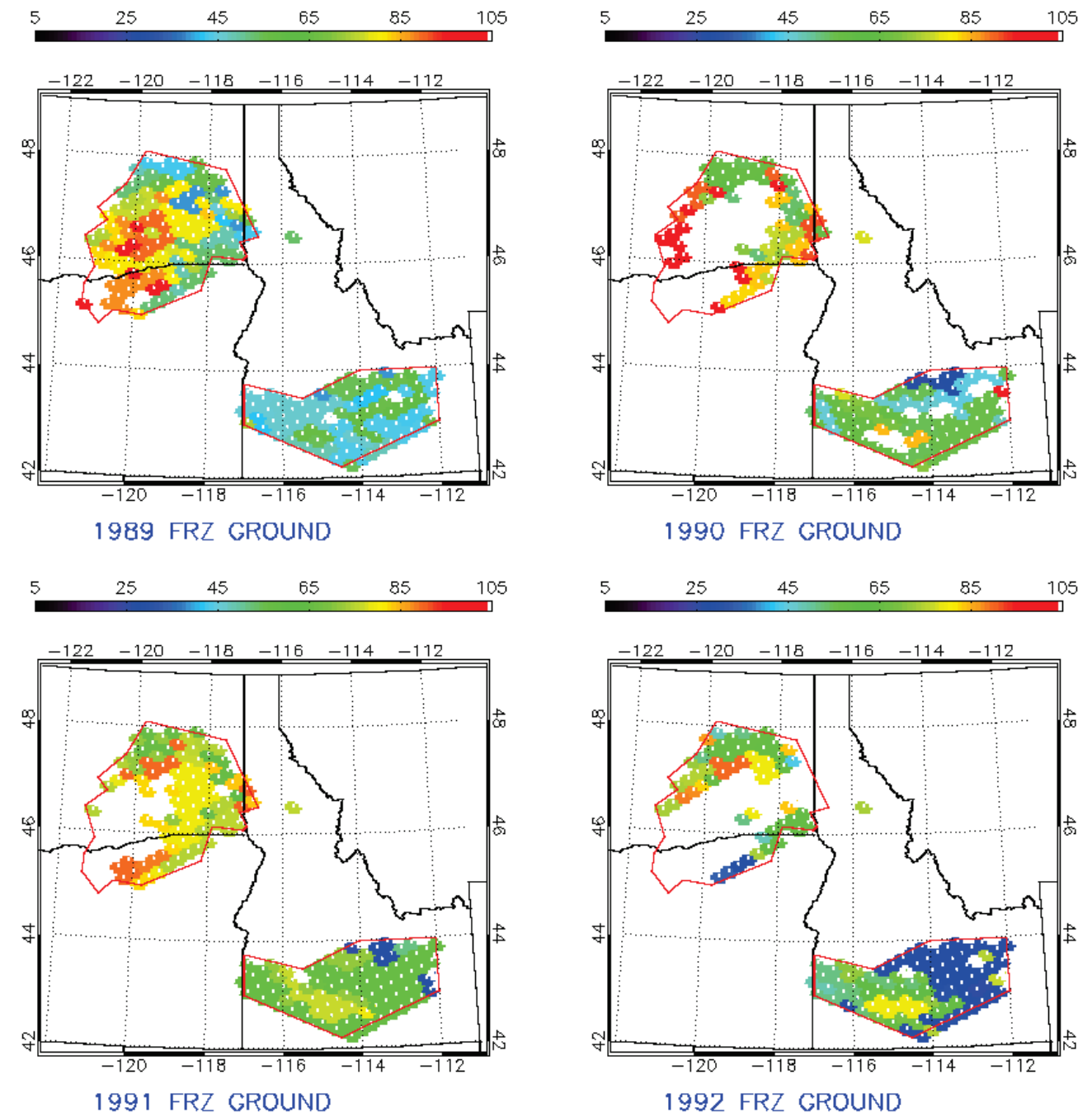

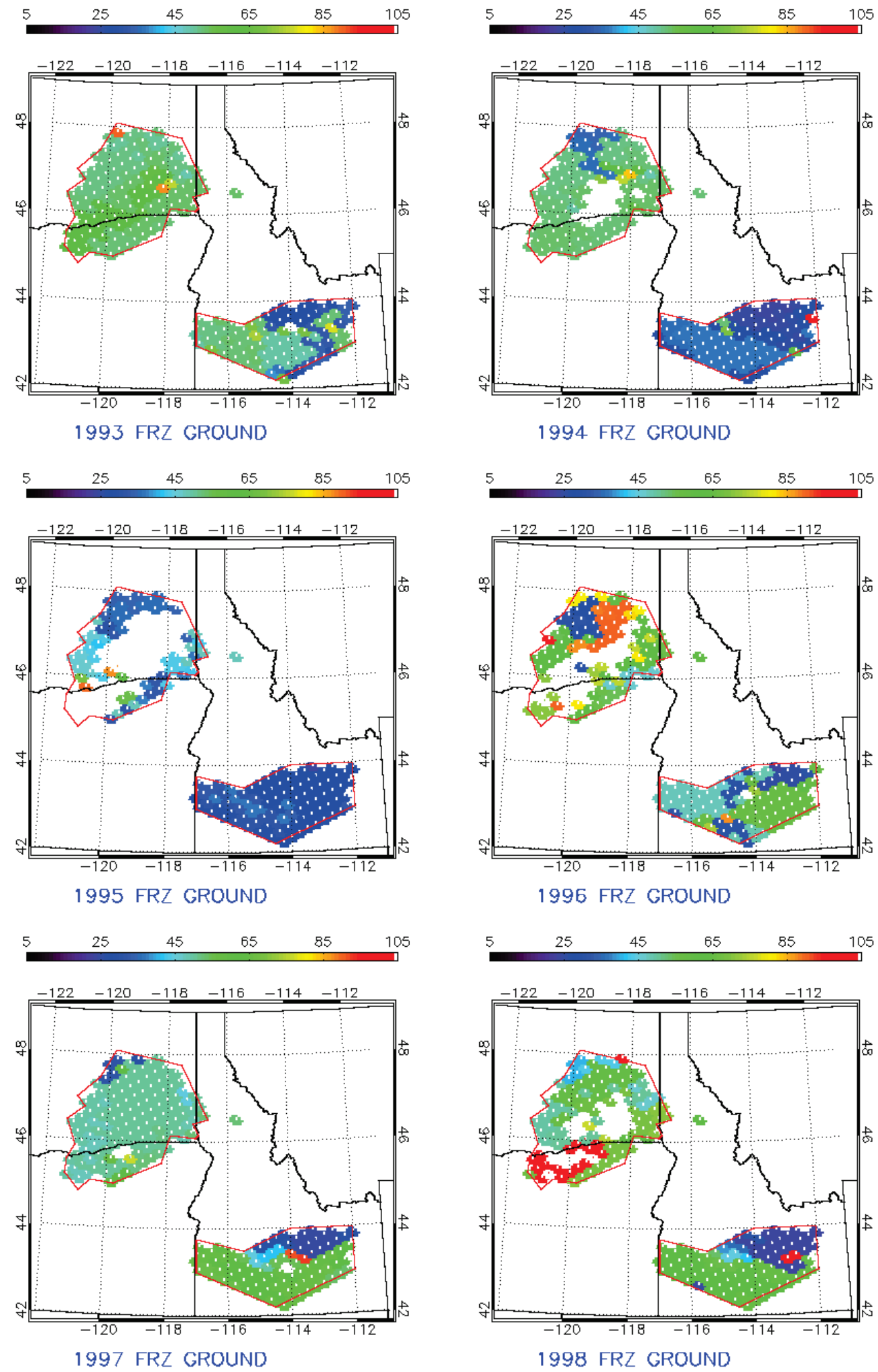

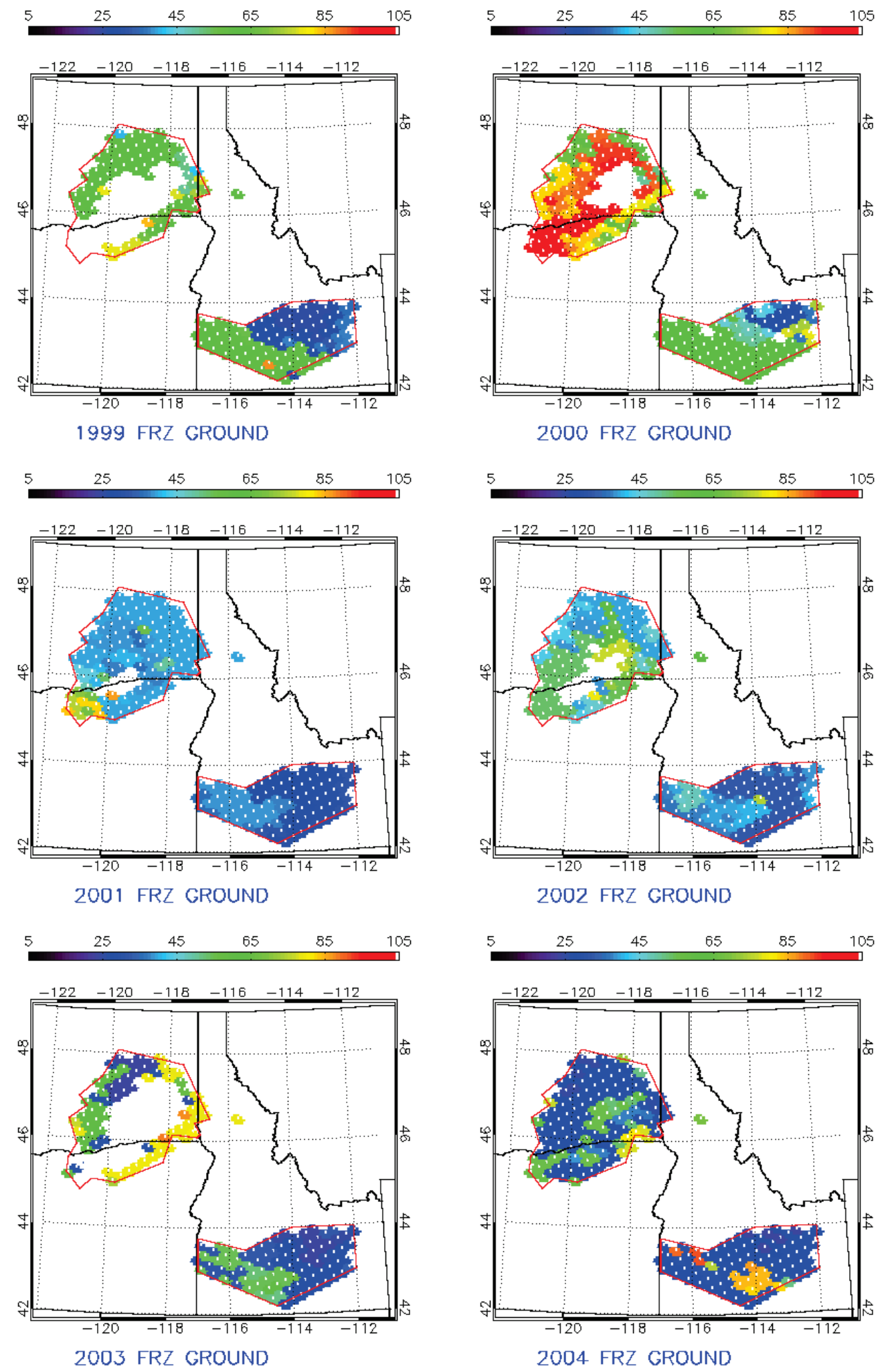

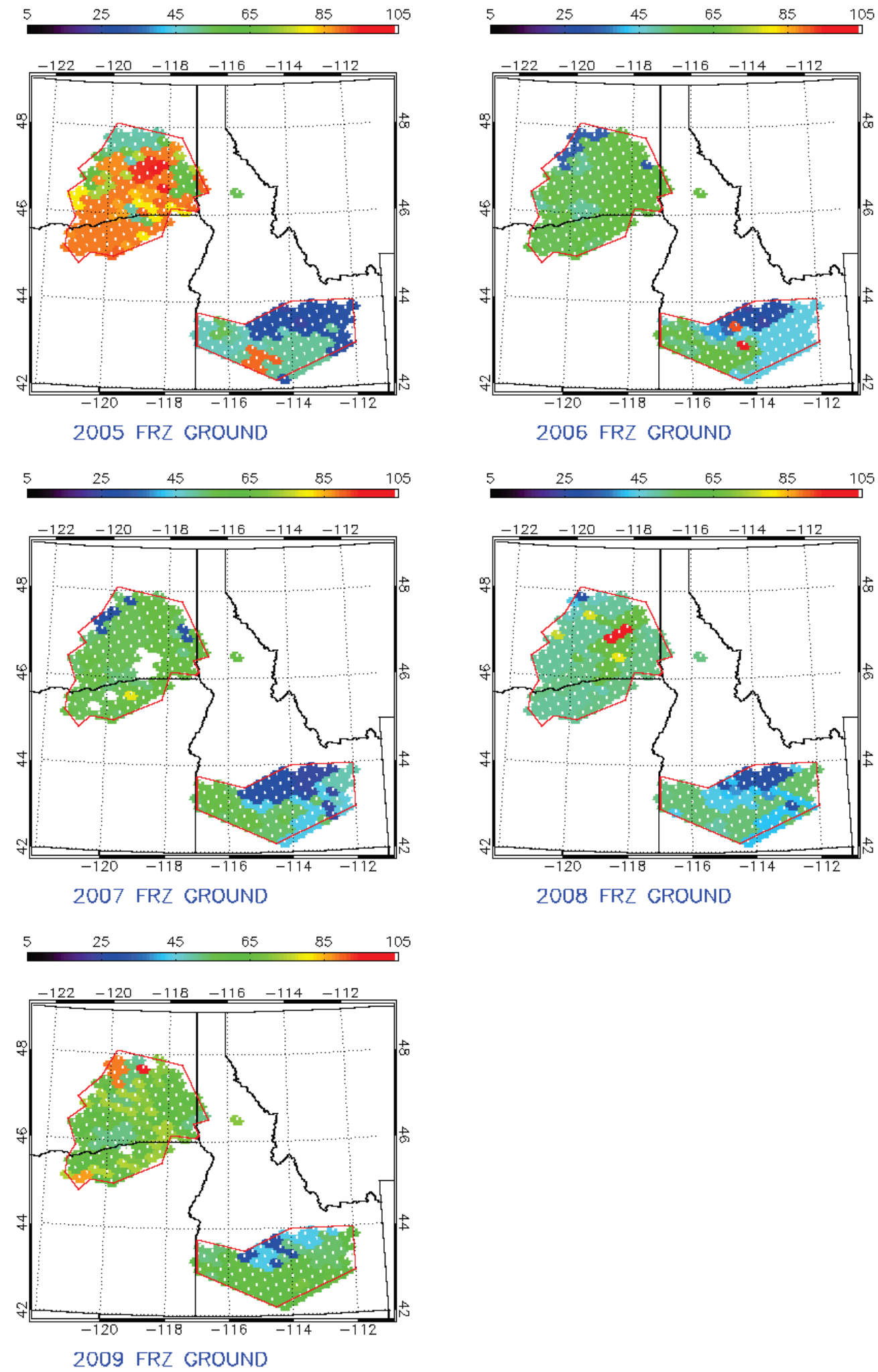

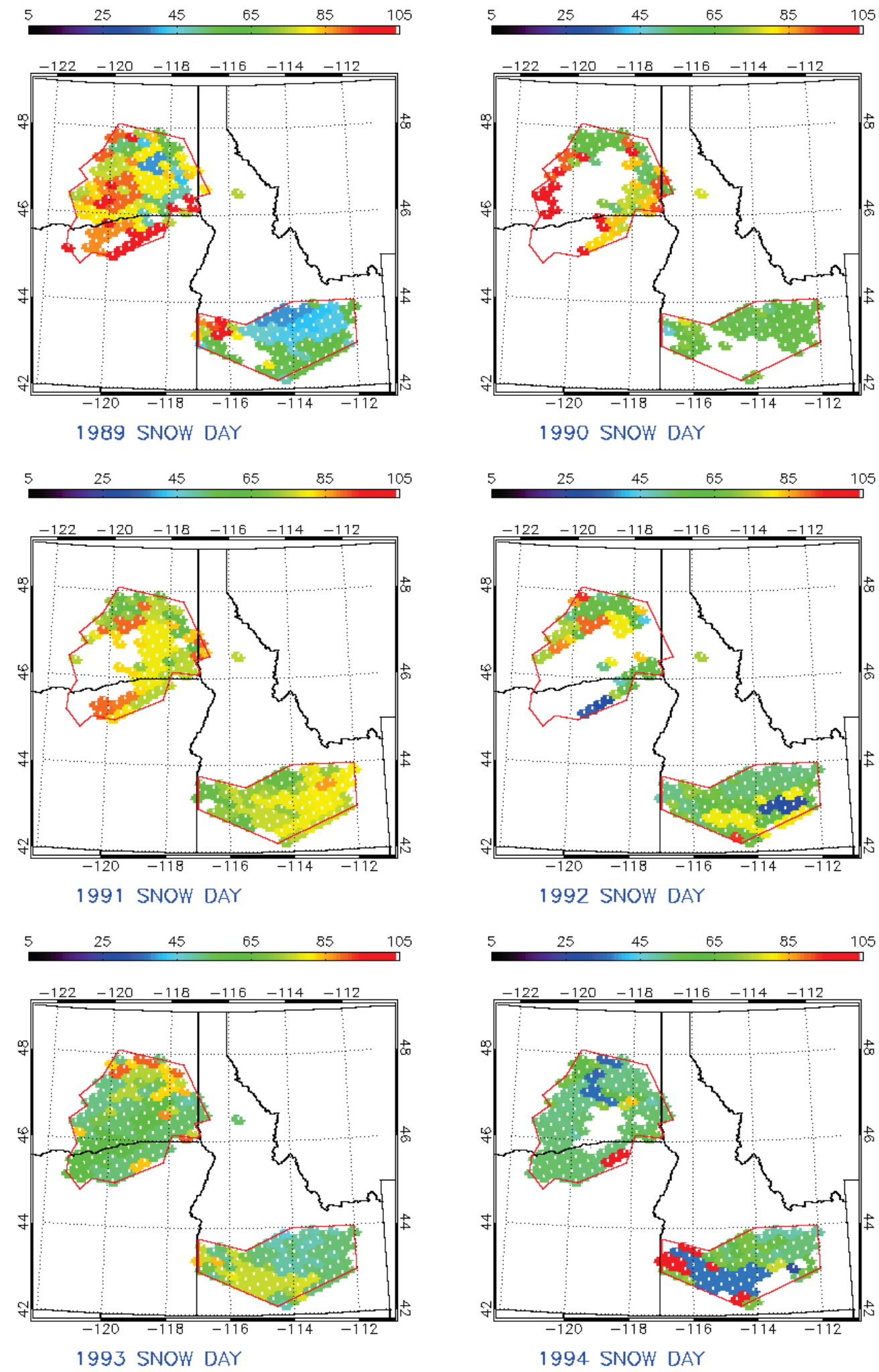

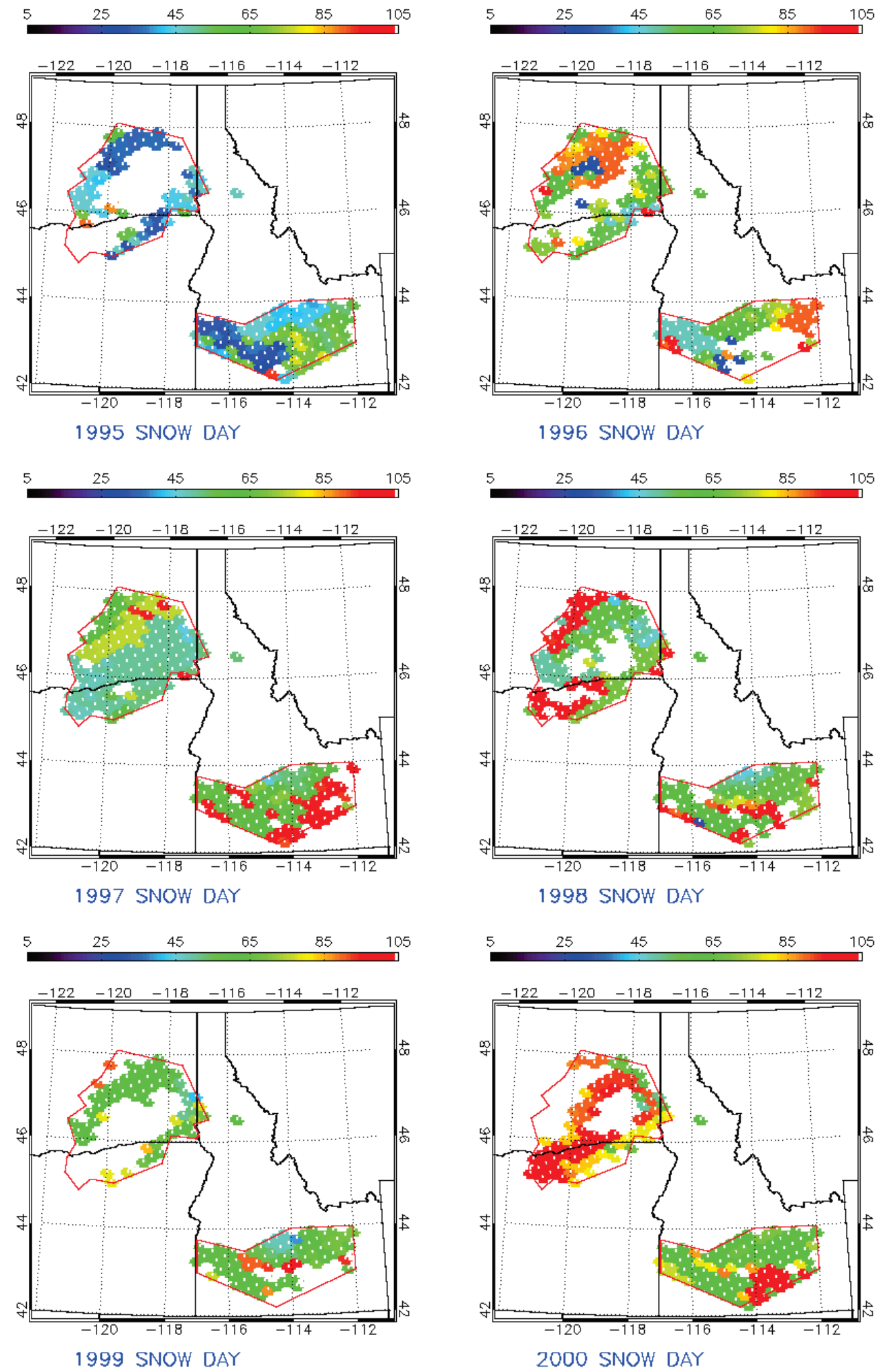

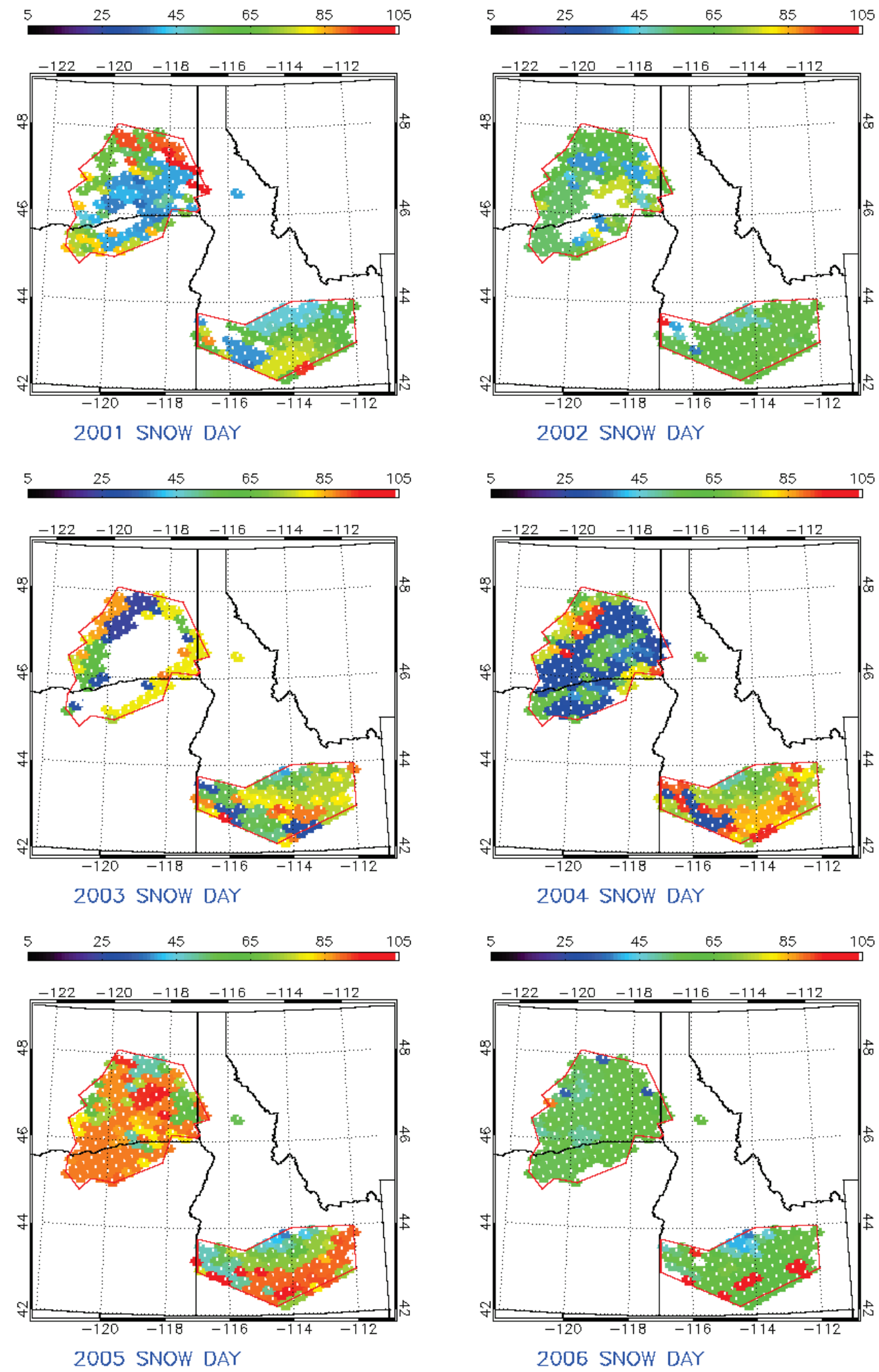

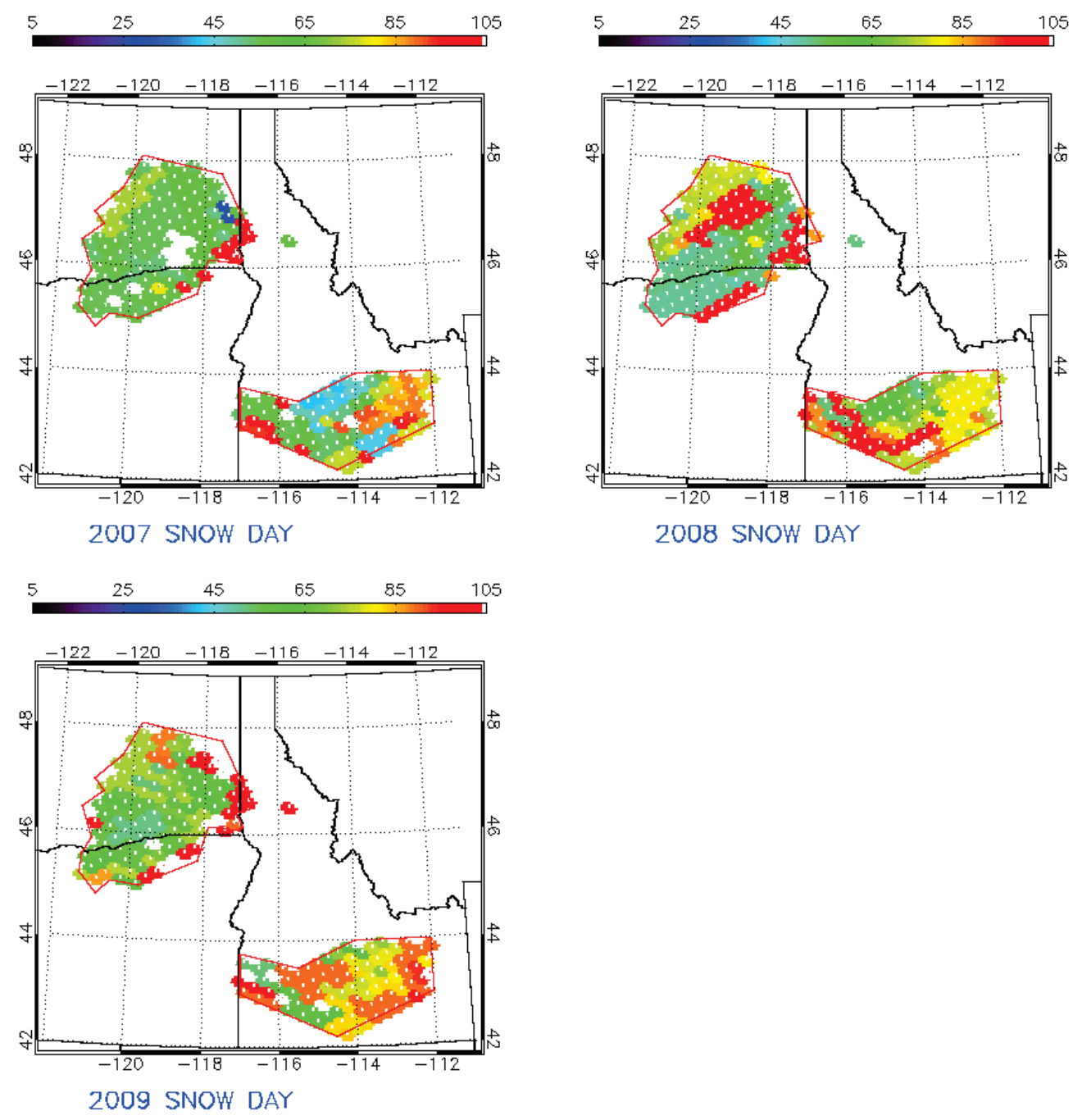


\section{Appendix C. Difference in Days Between Snow Cover and Frozen Ground and the End Day of Snow Season in the Columbia Plateau and Snake River Plain, Idaho, Oregon, and Washington, Water years 1989-2009}

The first set of color-coded maps show the 21 years (water years 1989-2009) of the difference in days of snow-covered ground minus the days of frozen ground (DIF) and the second set of maps show the 21 years of the water-year-end day of the snow season using regime analysis on the processed satellite remote sensing data (Melt). Each pixel of data covers an area of $15.5 \times 15.5$ miles and is in one of the two regions in the study area - the Columbia Plateau (upper left of map) and the Snake River Plain.
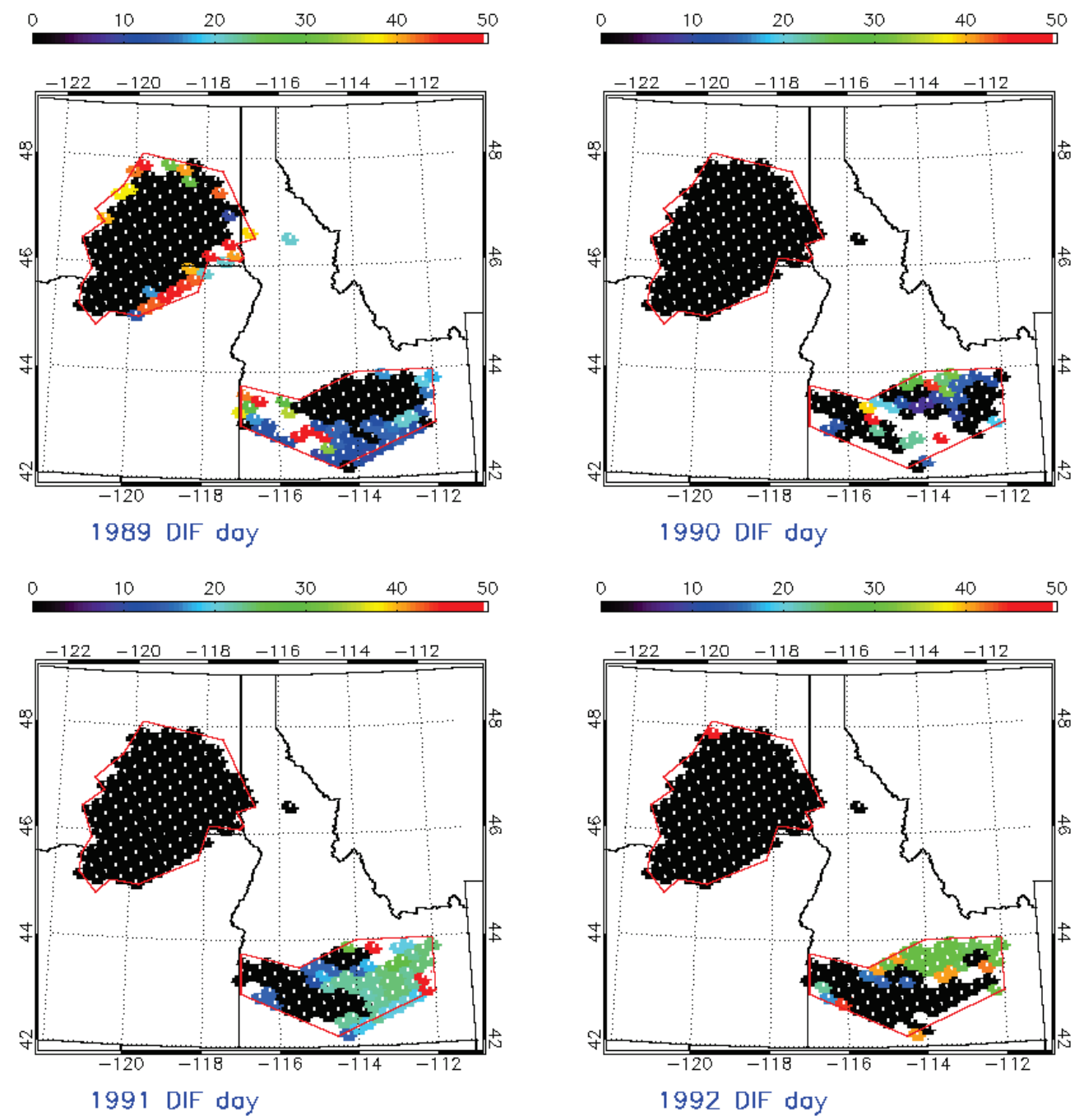

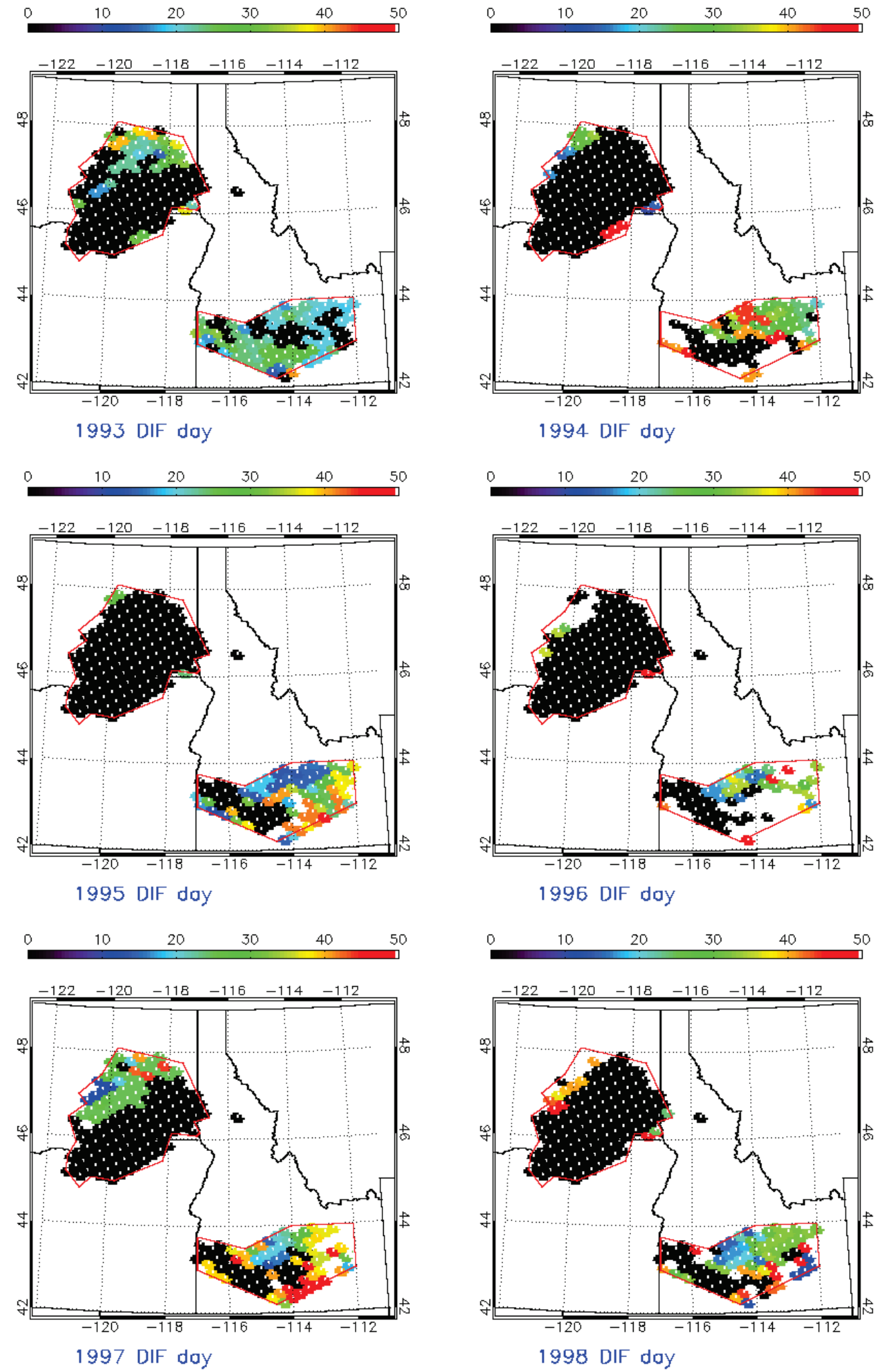

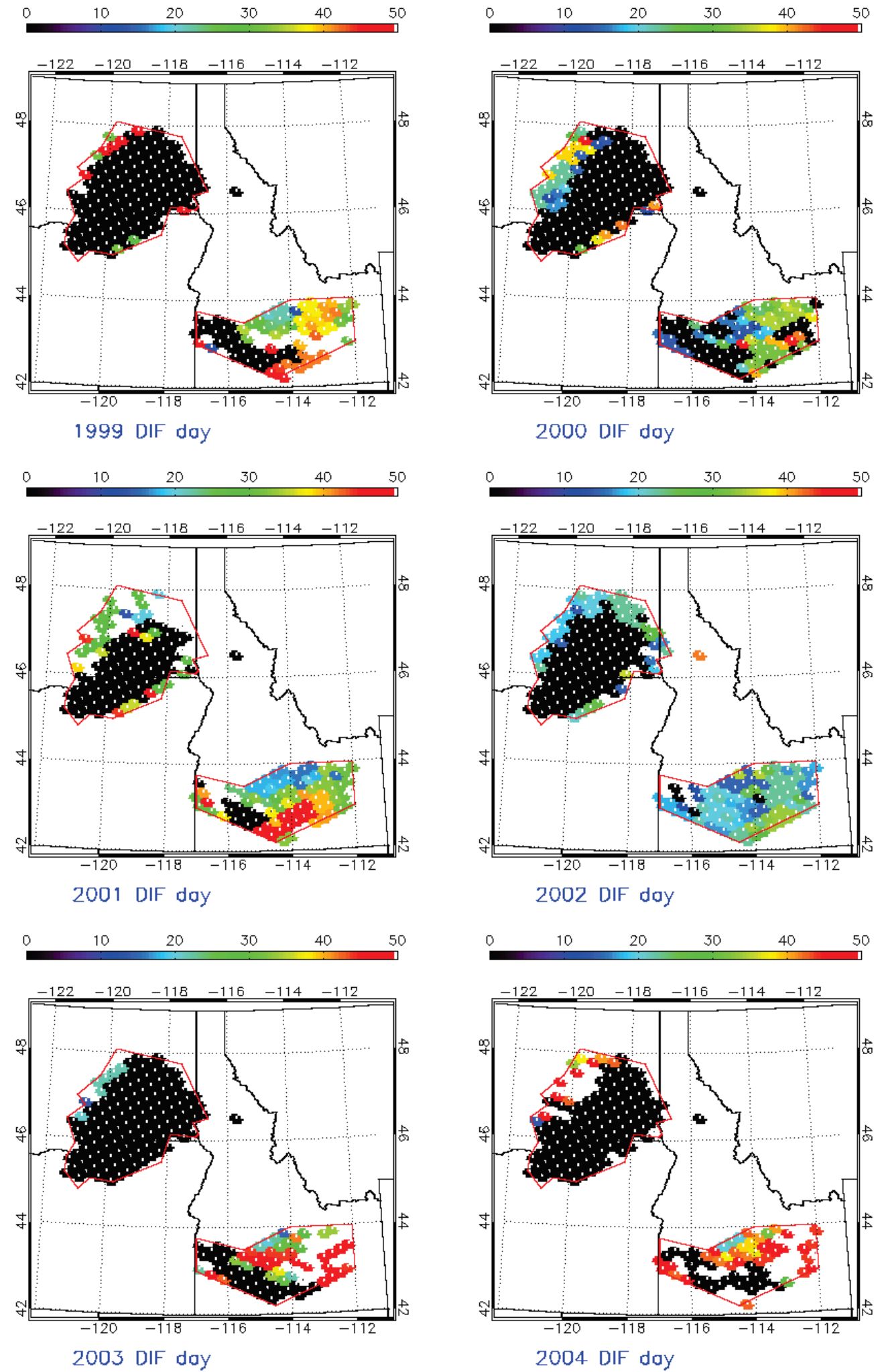

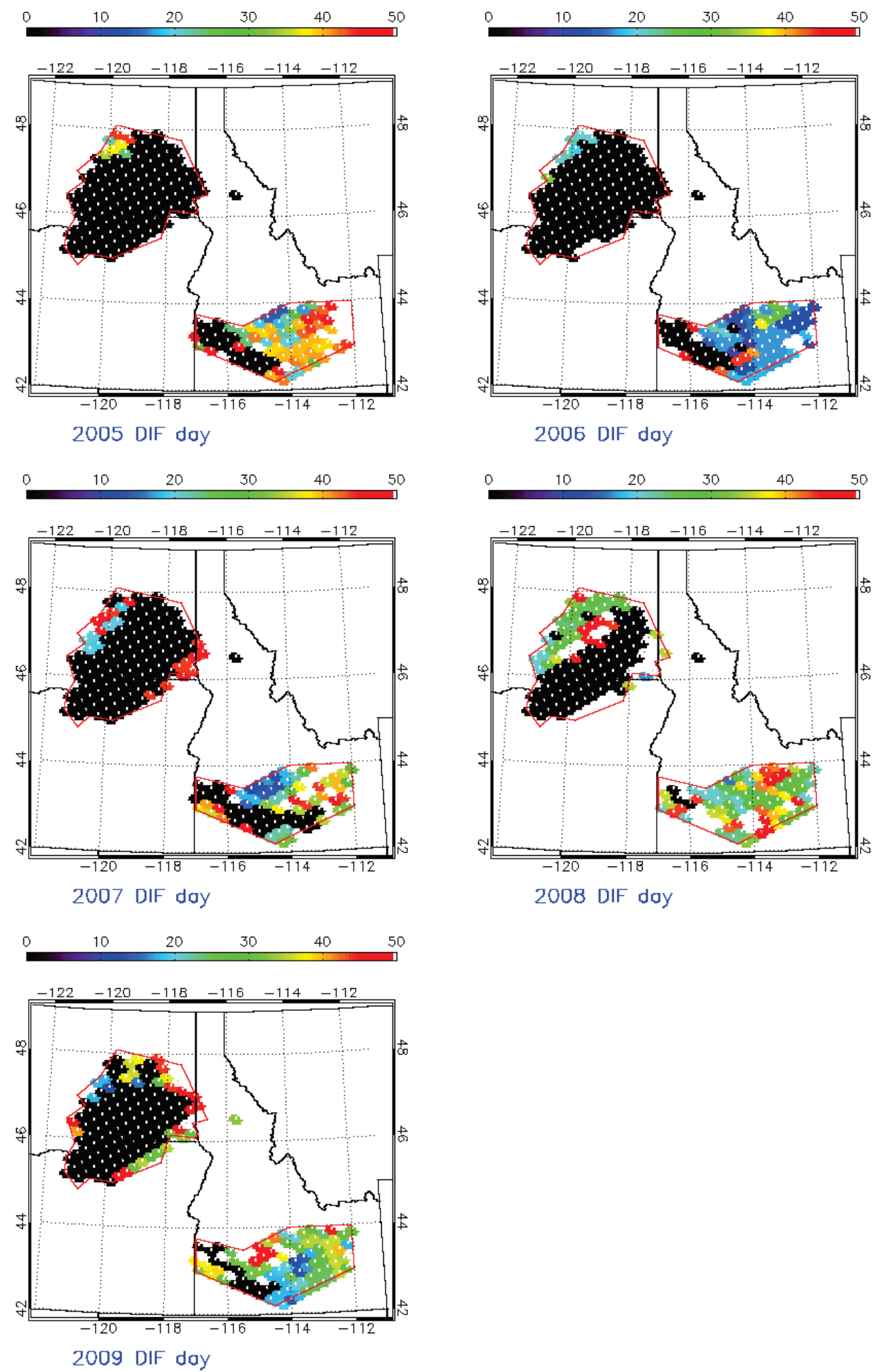

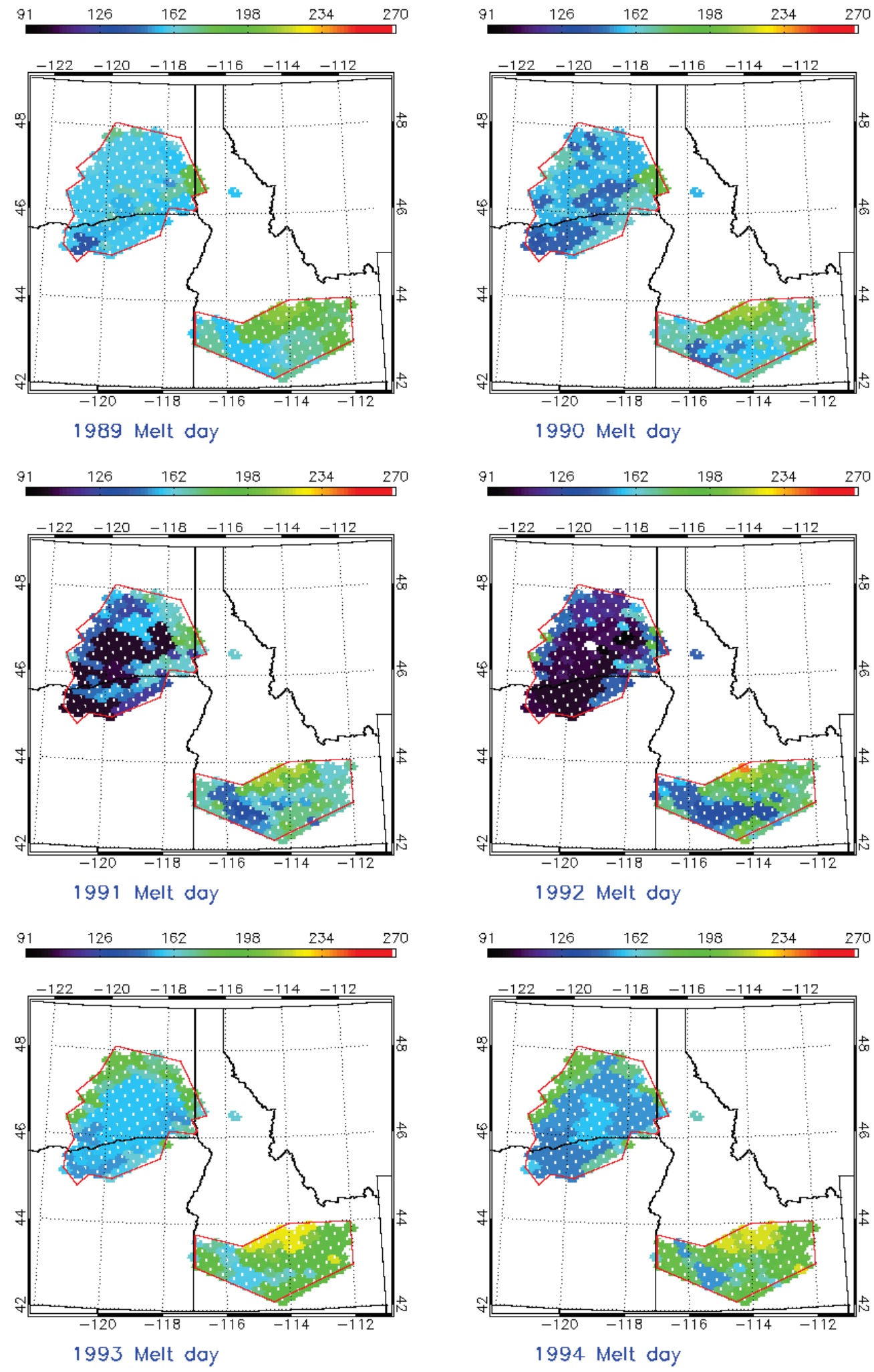

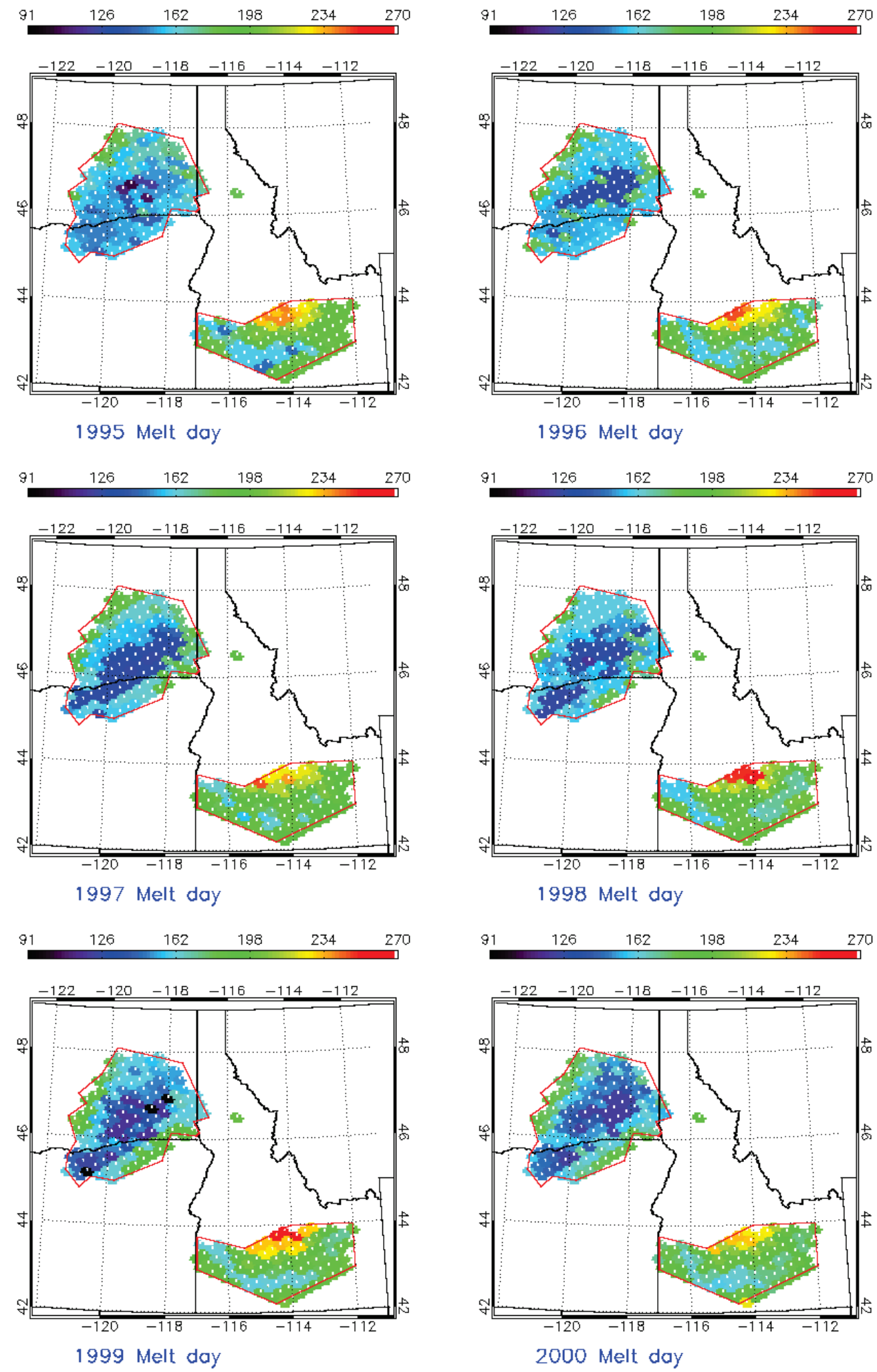

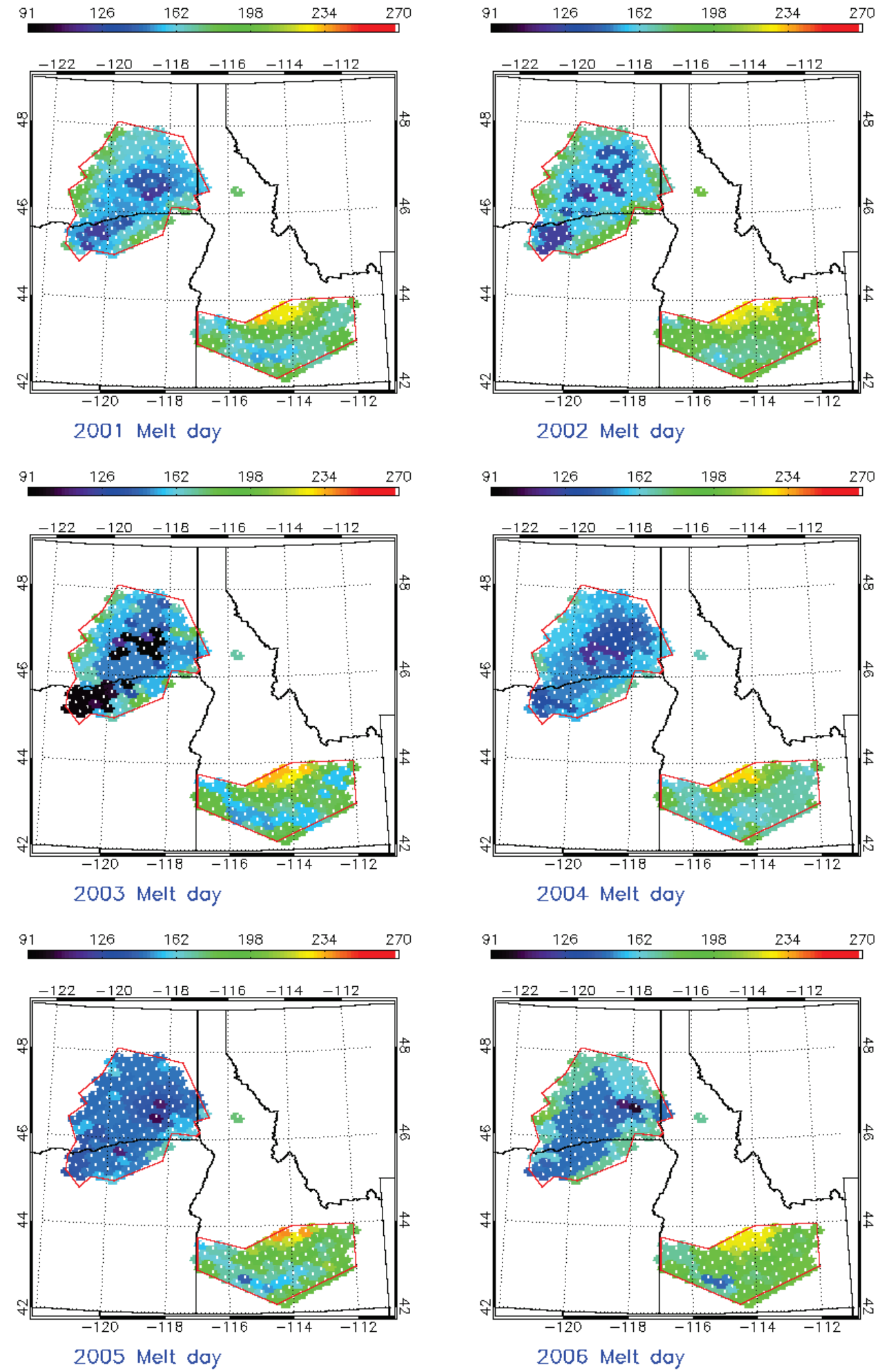

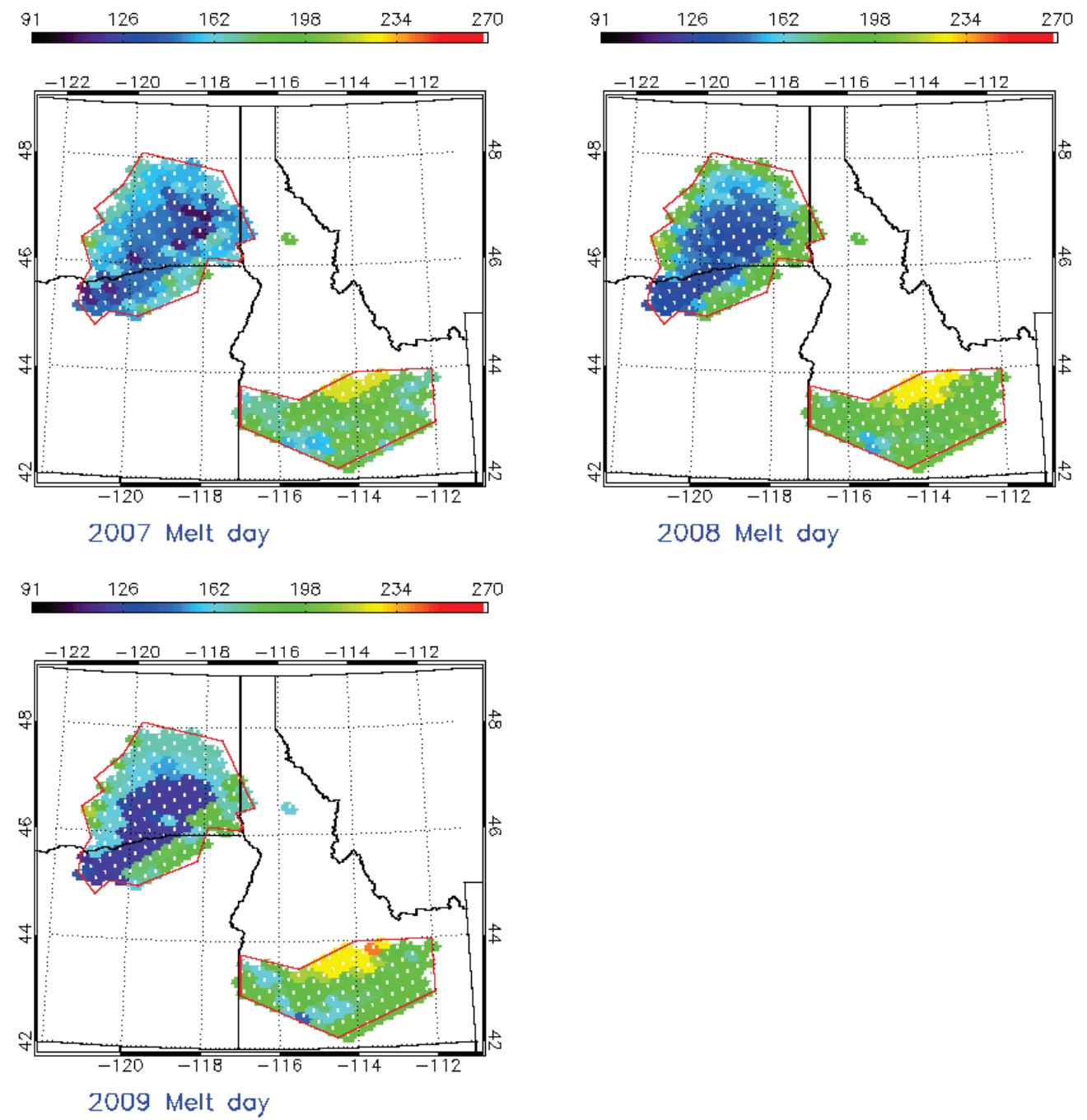

Publishing support provided by the U.S. Geological Survey

Publishing Network, Tacoma Publishing Service Center

For more information concerning the research in this report, contact the Director, Washington Water Science Center

U.S. Geological Survey

934 Broadway, Suite 300

Tacoma, Washington 98402

http://wa.water.usgs.gov 


\section{趈}

3

芯.

ํํำ

č

D

告

궁

․․

需

๕ั

产

몽

를

흫

옹

을

言

为

흘

훙

$\frac{2}{10}$

言

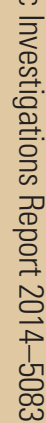

